Rehabilitation Research and Training Center on Disability Demographics and Statistics

\title{
A Guide to
} Disability Statistics from the National Health Interview

\section{Survey}

Benjamin H. Harris

Gerry Hendershot

David C. Stapleton

Cornell University 
For additional information about this paper contact:

Andrew Houtenville, Director

Rehabilitation Research and Training Center on

Disability Demographics and Statistics

Employment and Disability Institute

303 ILR Extension Building

Cornell University

Ithaca, NY 14853

(607) 255-5702 (Phone)

(607) 255-2763 (Fax)

This paper is being distributed by the Rehabilitation Research and Training Center on Disability Demographics and Statistics at Cornell University.

This center is funded to Cornell University by the U.S. Department of Education, National Institute on Disability and Rehabilitation Research (No. H133B031111). The contents of this paper do not necessarily represent the policy of the Department of Education, and you should not assume endorsement by the Federal Government (Edgar, 75.620 (b)).

The Co-Principal Investigators are:

Susanne M. Bruyère_-Director, Employment and Disability Institute, School of Industrial and Labor Relations, Extension Division, Cornell University

Richard V. Burkhauser-Sarah Gibson Blanding Professor and Chair, Department of Policy Analysis and Management, College of Human Ecology, Cornell University

Andrew J. Houtenville-Senior Research Associate, Employment and Disability Institute, School of Industrial and Labor Relations Extension Division, Cornell University

David C. Stapleton-Director, Cornell University Institute for Policy Research 


\section{TABLE OF CONTENTS}

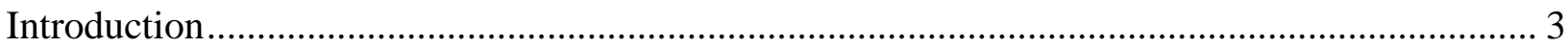

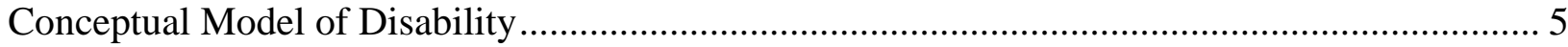

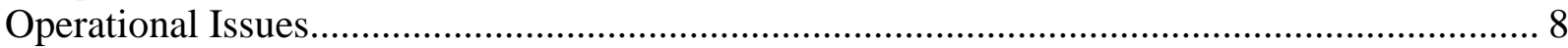

NHIS Background, Methodology and Definitions ………………………………….............. 9

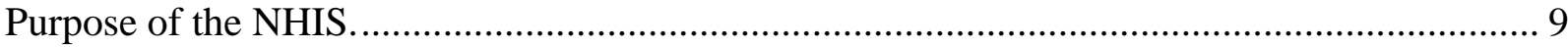

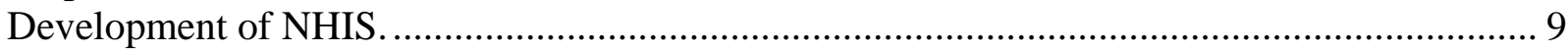

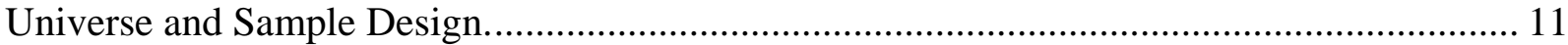

Data Collection and Methodology...................................................................................... 13

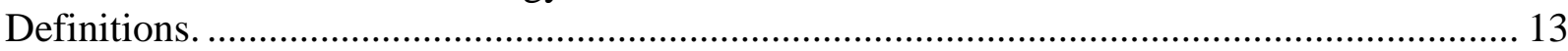

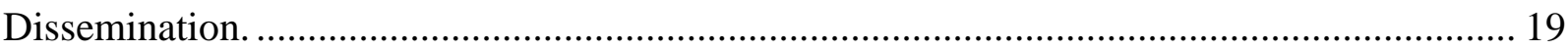

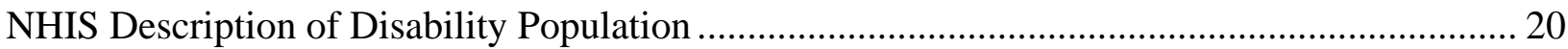

NHIS Economic Well-Being and Employment Estimates ........................................................ 22

Multiple Disabilities, Health Care, Insurance, and Health Conditions....................................... 25

Comparison to Other Data Sources............................................................................................. 29

Population and Prevalence Estimates................................................................................ 30

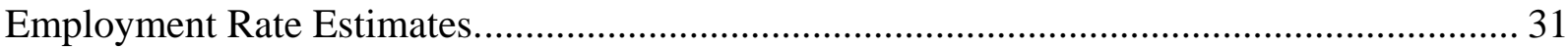

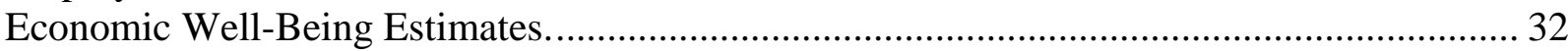

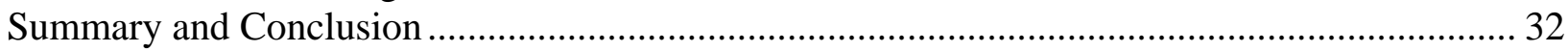

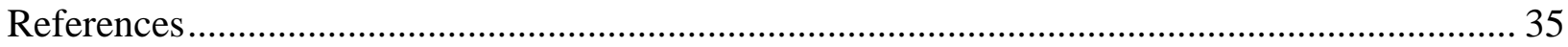

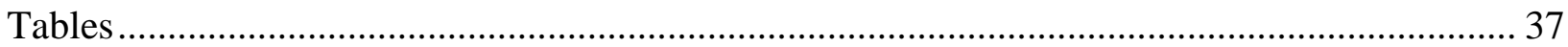

Appendix A. Imputed Income in the NHIS ......................................................................... 74

Appendix B. Sampling Structure and Variance Estimation.......................................................... 76

Appendix C. Estimated Standard Errors ..................................................................................... 78

Appendix D. Sample Sizes of Sub-populations ....................................................................... 110 


\section{Introduction}

Policymakers, service providers, disability advocacy groups and researchers use disability statistics for a wide variety of purposes. A common problem that these groups encounter is finding a data source, a disability definition and/or a statistical method that provides them with a needed disability statistic.

The mission of the Cornell StatsRRTC is to bridge the divide between the sources of disability data and the users of disability statistics. One product of this effort is a set of User Guides to national survey data that collect information on the disability population. The purpose of each of the User Guides is to provide disability data users with:

1. An easily accessible guide to the disability information available in the nationally representative survey;

2. Estimates of the population with disabilities, the disability prevalence rate, estimates of employment and estimates of economic well-being;

3. A description of the unique features of the dataset that will help disability statistics users determine whether the dataset can provide them with the statistic that they need; and

4. A description of how the dataset compares to other national data that are used to describe the population with disabilities.

This User Guide contains information on the National Health Interview Survey (NHIS), a nationally representative survey providing data on the health of the civilian, non-institutionalized population of the United States. The NHIS has been administered since 1957, and is conducted by the National Center for Health Statistics (NCHS), Centers for Disease Control and Prevention (CDC). ${ }^{1}$ The survey contains information on multiple aspects of health status, including activity limitations, injuries, health insurance, and access to and utilization of health care. The survey also provides information on household composition, socio-economic status, and family income and assets. While the NHIS asks a wide-ranging set of questions related to child health and disability, this User Guide will focus only on the health of working age adults. ${ }^{2}$ Lastly, this User Guide

\footnotetext{
${ }^{1}$ NCHS has administered the survey since its formation in 1960.

2 The current NHIS asks questions of all family members, including children, in the family core section of the survey. There is also a sample child section of the survey that
} 
analyzes data from 2002 because this was the most recent data available when the project began; in the future, we hope to update it with data from more recent years.

The current questionnaire structure includes two general areas: a core section that remains unchanged across years, and various sets of supplemental questions that change annually. The core consists of three general sections: the family core section, which collects demographic and health information on every member of the household, the sample adult section, which randomly selects an adult and collects additional healthrelated information for that adult, and a sample child section, which collects additional health-related information for the randomly selected child. In 2002, the supplemental topics included alternative and complementary medicine, vision, hearing, asthma, arthritis, child mental health, disability and secondary conditions: assistive technologies and environmental barriers, environmental health: lead paint, and child and adult immunizations. In other years, the supplemental questions have covered a variety of topics.

There are several strengths of the NHIS relative to other national surveys. The NHIS contains a large amount of information on health-related data of all the major surveys, including particularly unique and extensive data on health insurance, health care access and utilization, health status, health-related conditions and health behaviors. The NHIS also contains a broad set of data on disability-related topics, including the limitation of functional activities, mental health questions used to measure psychological distress, limitations in sensory ability, and limitations in work ability. Moreover, the NHIS questionnaire asks those persons who indicated a limitation to a functional activity the source or condition of their functional limitation. Additional strengths of the NHIS include its continuous administration over the past five decades, which allows for the comparison of some health trends, and the specialized information contained in the supplemental survey section.

There are several disadvantages to the data contained in the NHIS. One significant drawback is the omission of several segments of the population, including the

asks health-related questions specific to children. This User Guide will focus only on adult data due to difficulty in comparing child and adult disability. 
institutionalized population, the homeless population, nationals living abroad, and members of the armed forces (although families of active duty military members are included). The lack of data on institutionalized adults is particularly troubling in the disability arena, as there is likely to be a high prevalence of adults with disabilities in certain institutions, particularly long-term care facilities. ${ }^{3}$ One particular concern is that any trend in the extent to which people with disabilities live in institutions will affect trends in the prevalence of disability in the non-institutional population as well as the mean characteristics and socioeconomic status of those in that population. The NHIS shares this limitation with other major surveys, including the American Community Survey (ACS), the Current Population Survey (CPS) and the Survey of Income and Program Participation (SIPP), although the ACS is scheduled to begin surveying people living in institutions in 2006. Second, the NHIS has much less comprehensive sociodemographic information than some of the other major surveys, such as the CPS and SIPP. While the survey contains a section on income and assets, the NHIS has experienced a high rate of non-response for these types of questions. ${ }^{4}$ Moreover, income data are only reported at the family level, making analysis of personal income impossible. Third, due to confidentiality concerns, design of the NHIS sample does not allow for state-level estimates. ${ }^{5}$ This is a significant drawback when analyzing the impact of areaspecific public programs, or analyzing state-level changes in health status of the population with disabilities. ${ }^{6}$

\section{Conceptual Model of Disability}

One purpose of the User Guides is to describe the information on disability available in the various national surveys. An operational definition of disability is

\footnotetext{
${ }^{3}$ The majority of the institutionalized population consists of nursing home patients and incarcerated prisoners.

${ }^{4}$ See Appendix A for a complete discussion of imputed income data.

${ }^{5}$ Recently, NCHS put the large Metropolitan Statistical Area (MSA) identifiers on the public use file and provided the same information for years back to 1997, but stopped this practice in 2003. Currently, estimates can be made for large MSAs from 1997 through 2002.

${ }^{6}$ Special arrangements may be made with NCHS to have analysis conducted using smallarea identifiers.
} 
required to fulfill this purpose. Unlike age and gender, that are for the most part readily identifiable individual attributes, disability is usually defined as a complex interaction between a person's health condition and the social and physical environment. An environment that provides accommodation may allow a person with a health condition to function at the level of a person without a health condition. In this instance, the person may not consider her health condition a disability.

Two major conceptual models of disability are the World Health Organization's (WHO, 2001) International Classification of Functioning, Disability and Health (ICF) and the disability model developed by Saad Nagi $(1965,1976)$. Both of these conceptual models recognize disability as a dynamic process that involves the interaction of a person's health condition, personal characteristics, the physical environment and the social environment. Changes to any one of these factors over time can have an impact on a person's ability to function and participate in activities. Detailed descriptions of these models, as well as a comparison, can be found in Jette and Badley (2000) and Altman (2001).

In this User Guide, we adopt ICF concepts to create operational definitions of disability. The concepts used include impairment, activity limitation, participation restriction, and disability (see WHO, 2001). A prerequisite to each of these concepts is the presence of a health condition. Examples of health conditions are listed in the International Classification of Diseases, Tenth Edition (ICD-10) and they encompass diseases, injuries, health disorders, and other health related conditions. An impairment is defined as a significant deviation or loss in body function or structure. For example, the loss of a limb or vision loss may be classified as impairments. In some surveys, impairments are defined as long lasting health conditions that limit a person's ability to see or hear, limit a person's physical activity, or limit a person's mental capabilities. An activity limitation is defined as a difficulty an individual may have in executing activities. For example, a person who experiences difficulty dressing, bathing or performing other activities of daily living due to a health condition may be classified as having an activity limitation. In some surveys, activity limitations are identified based upon a standard set of activities of daily living questions (ADLs) and/or instrumental activities of daily living 
questions (IADLs). A participation restriction is defined as a problem that an individual may experience in involvement in life situations. For example, a working-age person with a severe health condition may have difficulty participating in employment as a result of the physical environment (e.g., lack of reasonable employer accommodations) and/or the social environment (e.g., discrimination). In some surveys, participation restrictions are identified by questions that ask whether the person has a long lasting health condition that limits his or her ability to work, or whether a health conditions affects his or her ability to go outside his or her home to go shopping, to church or to the doctor's office.

The final ICF concept that we use is a disability. The term disability is used to describe the presence of an impairment, an activity limitation and/or a participation restriction. This concept is similar to the definition used in the Americans with Disabilities Act of 1990 (ADA). The ADA defines a disability as "a physical or mental impairment that substantially limits one or more of the major life activities, a record of such an impairment, or being regarded as having such an impairment.”

While these concepts may seem to follow a progression- that is, an impairment leading to an activity limitation leading to a participation restriction-it is not necessarily the case. It is possible that a person may have a participation restriction without an activity limitation or impairment. For example, a person diagnosed as HIV positive may not have an evident impairment or activity limitation but may not be able to find employment due to discrimination resulting from his health condition. Similarly, a person with a history of mental illness, but who no longer has a loss in capacity or activity limitation, may also be unable to finding employment due to discrimination resulting from his health condition.

Figure 1 provides a useful summary of the ICF concepts. It illustrates that while there is an overlap across these concepts, it is possible that one of them can occur without a relation to the others. The universe of the ICF is the health of the population as a whole. The shaded area of Figure 1 illustrates the ICF concept of a disability. 
Figure 1. Simplified Conceptual Model of Disability Using ICF Concepts

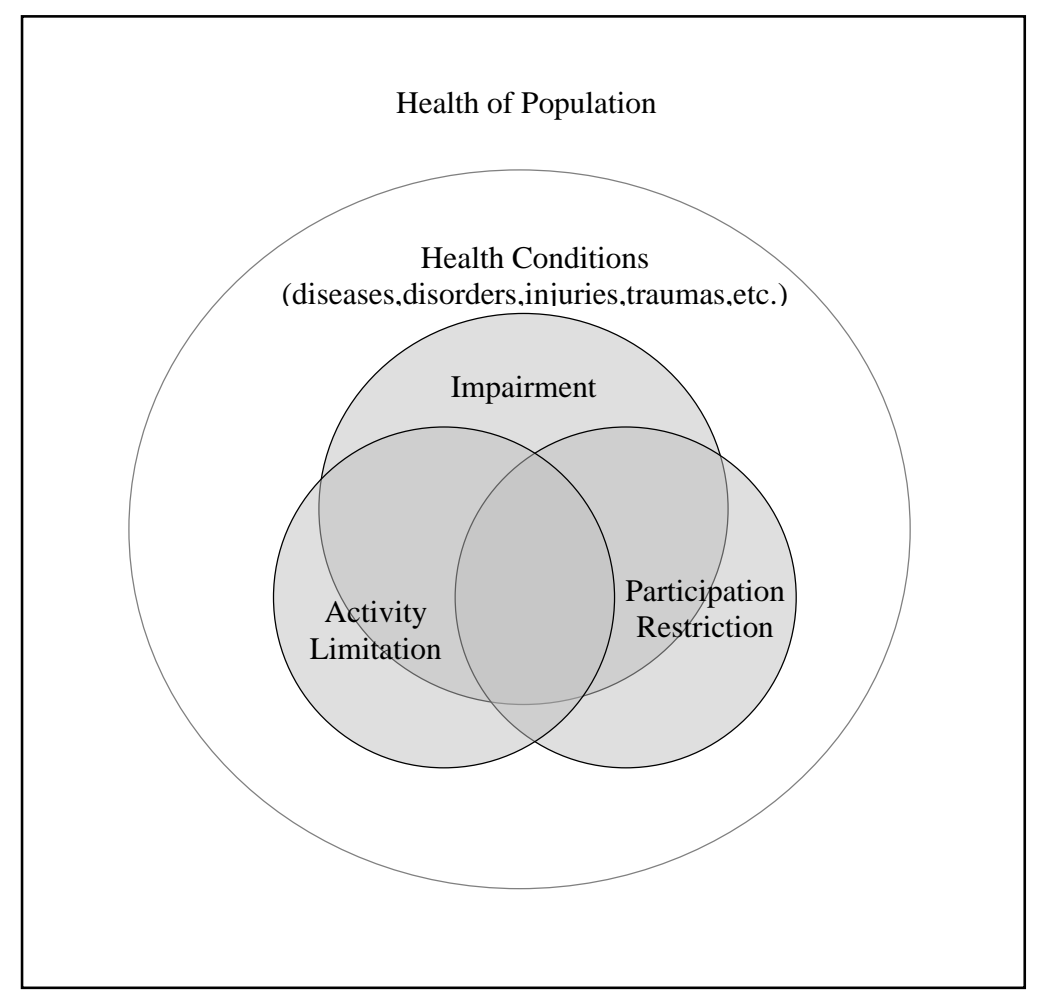

Operational Issues.

Translating the ICF concepts into operational definitions in surveys is not a straightforward task. Decisions to classify the questions into one of the three specific ICF categories were made based upon judgments and are not based upon well-defined rules from the ICF. In some cases, the classification is straightforward. In other cases, for example, the survey questions may be interpreted as both an activity limitation and participation restriction. Our approach in these cases was to make clear and consistent judgments so that it may be possible to make comparisons across the datasets. Using this approach provides a framework for comparisons across surveys and for comparisons to ICF concepts. 
The following section summarizes the development and purpose of the NHIS, outlines the data collection methodology, and provides a description of the various definitions used in this Guide.

\section{NHIS Background, Methodology and Definitions}

The survey methodology can have an important impact on the information that a survey collects on the population with disabilities. Mathiowitz (2000) provides a good review of the general methodological issues as well as those specific to the population with disabilities. The purpose of this section is to describe the development of the NHIS, the methods used by the NHIS to collect information on the population, and the precise definitions used to describe the population with disabilities.

Purpose of the NHIS.

The NHIS is the primary data source on the health of the civilian, noninstitutionalized population of the United States. The survey was initiated by an Act of Congress in 1956 "to produce statistics on disease, injury, impairment, disability, and related topics on a uniform basis for the Nation.” In general, the NHIS exists to monitor the health of the U.S. non-institutional population, and to display these characteristics by socio-economic and demographic characteristics. NHIS data are used within government agencies and the academic research community to monitor developments in the prevalence of illness, disability, and other health-related conditions. Researchers also rely on the NHIS to measure trends in the U.S. health care environment, including changes in health care access and utilization. The NHIS is also used to measure the efficacy of federal health programs; NCHS cooperates with other federal agencies to meet their needs for health data, such as the data needs of the National Health Objectives.

\section{Development of NHIS.}

The NHIS has been collected continuously since 1957, and is periodically modified to help the data better meet the needs of its users. In general, the structure and content of the "core" questionnaire is modified every 10 to 15 years, with the last major modification occurring in 1997. The sampling design of the NHIS is modified every 10 
years; the current sample design lasts from 1995 to 2005 and will be changed for the 2006 survey.

There is little effective difference in the general structure of the redesigned 1997 survey and the previous survey design. From 1982 to 1996, the NHIS consisted of two parts. The first section, known as the "core,” asked questions about health and demographic information. The second section consisted of a series of supplemental surveys that posed questions on current health topics. The “core” remained the same over this period, while the section on current health topics changed annually. In 1997, the redesigned NHIS intended to implement three general components: a basic module, a periodic module, and a topical module. The basic module is analogous to the "core" section of the 1982-1996 NHIS, while the topical module is analogous to the supplemental section of the earlier design. In NCHS documents, and this User Guide, the basic module is referred to as the "core" and the topical modules are referred to as “supplements.” The periodic core was designed and fielded in 1999, but has not been part of the survey since. Unlike the previous design, the basic module in the post-1997 NHIS has three components: the family core, the sample adult core, and the sample child core.

Broadly, the changes in the redesigned 1997 NHIS are the use of rotating content, an emphasis on self-reports, improvements in the measurement of health status and chronic conditions, and the capacity to analyze family-level data (Fowler 1996), although the use of rotating content has not been implemented. There are several notable specific changes to the 1997 core relative to the previous design. One significant change was the inclusion of six mental-health related questions aimed at measuring psychological distress; we use these questions to construct a measure of mental disability known as the Kessler Index (discussed further in section III). Also, the 1997 NHIS included two additional questions aimed at measuring physical and cognitive disability. The question aimed at measuring cognitive disability asks respondents if they experience limitations due to problems with memory or confusion. We chose not to include analysis of this information due to concerns with the ambiguity of the question. The redesigned NHIS also asks respondents whether they have difficulty walking without the aid of special equipment; we opted not to use data from this question due to the existence of a superior 
set of questions measuring physical disability, found in other parts of the survey. In addition, there were a few dozen minor changes to the 2002 NHIS core relative to the 2001 NHIS. ${ }^{7}$ The only one of obvious relevance to our analysis is changes in the skip pattern for question AHEARST, which asks: "which statement best describes your hearing without a hearing aid? Good; a little trouble; a lot of trouble; deaf.”8

The sample design changes every 10 years, with the most recent sample design occurring in $1995 .{ }^{9}$ Many of the changes in sample design are technically complex and beyond the scope of this paper (see NCHS 2000 for a complete discussion of the changes in sample design between periods). One notable change in sample design, however, concerns the oversampling of particular populations. The 1973-1984 sample design did not oversample any population, while the 1985-1994 sample design included an oversampling of the black population in the United States. The current sample design, which was implemented in 1995, oversamples both black and Hispanic populations. The 2006 redesign will reportedly include oversampling for Asian and elderly persons as well. Other notable changes include the methods in which the NHIS adjusts for nonresponse (see NCHS 2002 for a detailed explanation) and the structure of the complex sample design used by NHIS ${ }^{10}$ (see NCHS 2000 for a detailed explanation). Lastly, it should be noted that approximately 10 percent of assigned interviews were not attempted due to budget constraints in 2002.

\section{Universe and Sample Design.}

The target universe of the NHIS is all dwelling units that contain members of the civilian noninstitutionalized population in the United States. As stated earlier, the NHIS sample does not include those residing in institutions, (including those in prisons and

\footnotetext{
7 There are often minor changes to the NHIS questionnaire in each year, see (NCHS 2003) for a complete description of the changes specific to the 2002 NHIS questionnaire. ${ }^{8}$ In 2001, AHEARST followed a question that asked "Have you ever worn a hearing aid?” In 2002, an intermediate question about the frequency of hearing aid use was asked of those persons who had worn a hearing aid.

${ }^{9}$ For a complete description of the change in NHIS survey design over time, see Ch. 2, Table 1 in NCHS 2000.

${ }^{10}$ Specifically, the first level of stratification changed from census region to state, increasing the number of primary sampling units from 198 to 358.
} 
long-term care facilities), members of the active duty armed forces, or U.S. nationals living abroad. In 2002 the NHIS sample consisted of 36,161 households (36,831 families) that yielded 93,386 persons. For the sample adult component, 31,044 adults were interviewed; this sample forms the basis for analysis in this User Guide. The total household response rate was 89.6 percent. Of the 10.4 percentage points representing the non-interview rate, 7.1 percentage points were due to respondents' refusal to participate while 3.3 percentage points were due to an inability to locate an eligible respondent.

The NHIS sample is based on a complex design incorporating stratification, clustering, and multistage sampling. The purpose of multi-stage, clustered sampling is to achieve greater administrative efficiency and to keep survey operations manageable and cost-effective. Because the NHIS is conducted via in-person interviews, costs associated with data collection are significant. Given these cost constraints, simple random sampling would be impossible because the sample would be too geographically dispersed. Further, black and Hispanic populations are oversampled to improve the precision of estimates for statistics on these subpopulations. ${ }^{11}$

For point estimates of a certain population, NCHS produces weights that can be used to estimate national prevalence rates and other statistics for a given variable. In this User Guide, the NHIS variable 'final annual sample adult weight' is used. This weight is developed to include design, ratio, non-response, and post-stratification adjustments for the population sampled in the sample adult core. Because the NHIS does not employ simple random sampling, more complex variance analysis must be used in computing the variance of point estimates. Using standard statistical procedures will produce, in general, standard errors that are too small, and the probability of a type I error (rejecting a true null hypothesis) under standard hypothesis tests will be larger than the specified significance level (i.e., tests will be biased toward rejecting the null hypothesis). See Appendix B for greater detail about sampling structure and variance (standard error) estimation.

${ }^{11}$ Black and Hispanic populations would still be represented in the absence of oversampling; the oversampling procedure is used to improve the stability of the point estimations. 


\section{Data Collection and Methodology.}

The U.S. Census Bureau is the data collection agent for the NHIS. About 400 interviewers are used; they are trained by health survey supervisors at regional U.S. Census Bureau offices and elsewhere. Data are collected by in-person interviews, using Computer Assisted Personal Interviewing (CAPI); while the questionnaire itself is written in a computer language, a simplified CAPI Reference Questionnaire, or CRQ, is available for reference.

For the family core component of the basic module, all adults over age 17 who are present in the home are invited to participate in the interview. A representative adult residing in the home is asked to provide information for children and absent adults. For the sample adult core, one adult in the household is randomly selected and responds for his or her self, if possible. For the sample child core, one child is randomly selected, and information on that child is provided by a knowledgeable adult residing in the household. Interviewers are required to make a specified number of attempts to contact the sample adult in person or by telephone. If the sample adult is contacted, but unable to respond due to a disability or health problem (in the judgment of the interviewer), a proxy respondent may be interviewed.

\section{Definitions.}

A description of the survey questions and the methods used to produce data on disability, demographics, economic well-being, and employment is shown in Table 1.

Disability. Data on disability are derived from questions in both the person-level file of the family core, and the sample adult file. We use these questions to define six disability types, two corresponding to the ICF concept of participation restrictions, one corresponding to the concept of activity limitation, and three corresponding to the concept of impairment. We chose these definitions for illustrative purposes and for facilitating comparisons between the NHIS and other surveys - especially the ACS. The definitions we use are conceptually similar to the six disability categories used by the ACS. Data on participation restrictions and activity limitations are derived from the 
person-level file of the family core, while data on impairments are derived from questions included in the sample adult survey.

The family core has six substantive sections; questions on disability are derived from the 'health status and limitation of activity section.' The health status and limitation of activity section contains survey questions on work limitations, limitations to ADLs, IADLs, difficulty walking without special equipment, and difficulty with cognition. Within the sample adult survey, the NHIS asks respondents questions concerning sensory disability, physical disability, and mental health. We used data from these questions to create disability definitions consistent with the ICF concept of impairment.

For the participation restrictions, we used questions FHS.170 and FHS.190 to measure work limitation and question FHS.150 to measure difficulty with IADLs. FHS.170 measures whether a physical, mental or emotional condition prohibited an individual from working at the time of the survey. Respondents answering 'no' to question FHS.170 were asked a follow-up question, FHS.190, concerning whether the respondent was limited in kind or amount of work due to a physical, mental, or emotional problem. Because being asked question FHS.190 was conditional on a respondent answering 'no' to FHS.170, the two different classifications of work limitation are mutually exclusive.

To measure limitations to IADL, we used question FHS.150, which asks if a respondent requires assistance in handling routine needs, such as everyday household chores, doing unnecessary business, shopping, or getting around for other purposes, due to a physical, mental or emotional problem. This is consistent with the ICF concept of participation restrictions.

The question measuring ADL disability is consistent with the ICF concept of activity limitation. Question FHS.070 asks whether a respondent requires assistance with personal care needs, such as eating, bathing, dressing, or getting around inside the home, due to a physical, emotional, or mental problem. For those answering in the affirmative, a series of six questions was asked concerning the specific personal care needs that an individual required help completing. 
In 1997, the NHIS began asking respondents in the sample adult survey a series of six questions about psychological distress. Specifically, respondents were asked how often, in the past 30 days, they felt so sad that nothing can cheer you up, nervous, restless or fidgety, hopeless, that everything was an effort, worthless $\}$. Kessler et al. developed the series of questions as a measure of non-specific psychological distress. (See Kessler et al. 2002 for a detailed description of the development of the set of questions.) The authors developed an index, referred to as the Kessler Index, which assigned a score to the response to each of the six questions (none of the above/don't know/refused $=0$, a little of the time $=1$. some of the time $=2$, most of the time $=3$, all of the time=4). If the aggregate total of these six questions was in excess of 12, the respondent was classified as having a mental disability. The goal of the Kessler index was to measure non-specific psychological distress, rather than disorder-specific diagnostic measures of mental illness. The authors note, however, "People with a wide range of mental disorders typically have high scores on this core dimension of non-specific distress.” (Kessler et al. 2002, p. 961). Further studies have shown that the Kessler Index is an excellent predictor of serious mental illness, although the measure is not successful in identifying the nature of the mental illness (Kessler et al. 2003). Thus, while this measure of mental illness can be used to track the development of serious mental illness over time, it fails in identifying trends in specific mental illnesses, or even general categories of mental illness, such as cognitive or affective disorders. The notion of non-specific psychological distress is consistent with the ICF classification of impairment.

Within the 'limitation of activities' section in the sample adult survey, respondents are asked a series of 12 questions concerning the degree of difficulty a respondent had with a particular activity (questions AHS.091 and AHS.141). We use data from nine of these questions; see Table 1 for a list of the specific questions. If a respondent answered that any of the nine activities was 'very difficult' or that he/she couldn't perform the activity, the respondent was classified as having a physical disability.

The sample adult survey contains questions on sensory disabilities. We use data from two questions to define sensory disabilities. An individual is classified as having a 
vision disability if she or he indicates blindness in question ACN.440. A respondent is classified as having a hearing problem if she or he indicates deafness, or 'a lot of trouble' hearing without special equipment. This definition is consistent with the ICF concept of impairment.

While this series of disability definitions forms a comprehensive definition of disability overall, there may be some individuals considered to have a disability under the conceptual definition of disability but not captured as having a disability under these definitions. The set of questions forming the basis for the Kessler Index score asks respondents about their mental health in the past month, but could potentially omit those persons experiencing severe psychological distress earlier in the survey year. Also, those persons with cognition difficulties, but not experiencing psychological distress, may not be captured by this definition of mental disability.

Similarly, there may be some individuals who classify as having a disability due to a temporary condition or circumstance. The questions forming the basis for the definition of physical disability ask respondents about immediate physical limitations; the period of time the respondent has been physically limited is not recorded. Likewise, the questions forming the basis for the Kessler Index ask respondents about their mental health over the past 30 days; those experiencing psychological distress at earlier points in the year would be excluded from this classification.

There are data from several questions in the redesigned NHIS questionnaire, directly asking about disability, that we have opted to omit from this User Guide. This set of questions includes a question concerning the degree of difficulty walking without special equipment and limitations due to confusion or insufficient memory. ${ }^{12}$ We have also elected to omit data from a set of questions in the sample adult survey that ask about difficulty completing certain tasks and participating in certain activities. ${ }^{13}$

We chose to omit data from the question asking about difficulty walking without special equipment due to the existence of superior questions concerning physical

12 See Table 1 for the specific wording of these questions.

13 This set of three questions (AHS.171) is asked in the sample adult survey. 
disability in the sample adult section, namely the set of ten questions ${ }^{14}$ concerning degree of difficulty completing various physical tasks. This set of ten questions forms a standard set of questions frequently used to measure disability. Due to the existence of the set of standardized questions, and concerns with the questions confounding disability and environment, we also opted to omit data from three additional questions concerning degree of difficulty completing tasks and participating in activities, added by NCHS in the 1997 questionnaire redesign. Lastly, we opted not to use a question regarding limitations associated with periods of confusion, due to the ambiguity of the question and our concerns that those designated as having a mental disability by responding in the affirmative would not necessarily match the criteria established for having a mental limitation.

Demographics. Demographic data is derived from the 'demographic info' section of the household survey and the 'family relationships and verification of demographic data' section of the family core. Many of the demographic questions are straightforward. Respondent gender is derived from question HHC.110: “Are you male or female?” and respondent age is derived from question HHC.120: "What is your age and date of birth?”

We use NCHS recodes for the race and ethnicity questions. Race is derived from HHC.200: "What race do you consider yourself to be?” We use the race recode variable 'racerp_i,' which contains details for 4 of the 5 OMB race groups (white only, black only, Asian only, and American Indian/Alaskan Native only), in addition to an "other race" category and a category for multiple race. Native Islander/other and Pacific Islander identifications are included in the "other" race category for confidentiality reasons. Respondents with multiple Asian or AIAN races are coded as Asian only or AIAN only, rather than as "multiple race." Ethnicity (i.e. Hispanic/non-Hispanic) data are derived from HHC.170: “Do you consider yourself to be Hispanic/Latino?” We used the ethnicity recode variable 'origin_i,' which included imputed values for missing responses to this question.

\footnotetext{
${ }^{14}$ These questions are asked under sample adult questions AHS.091 and AHS.141.
} 
Data on education are derived from FSD.010: "What is the highest level of school completed or the highest degree received?” Adults were presented with multiple options for educational levels. In addition to ‘don’t know,' categories include never attended; grades $1-11 ; 12^{\text {th }}$ grade, no diploma; high school graduate; GED or equivalent; some college, no degree; AA degree, technical or vocational, AA degree, academic program; bachelor’s degree (BA, AB, BC, BBA); master's degree (MA, MS, MEng, Med, MBA); and doctoral degree $(\mathrm{PhD}, \mathrm{EdD})$. The NHIS does not have any educational codes for special education for adults. ${ }^{15}$

Economic Well Being. Poverty rates were derived from the constructed variable rat_cati, which contains the ratio of family income to poverty in 14 different categories (e.g. under 50 percent, 50 to 74 percent, etc.) This is a family-level variable, so all members of the same family have the same value for this variable. NCHS released imputed values for family income (and income to poverty ratios) in five separate and distinct datasets to account for the variability associated with the imputation of income data. Our values for imputed poverty ratios are the simple average of the variable imputed income to poverty ratio for all five datasets.

Family income in the NHIS is derived from three questions, FIN.250, FIN.260, and FIN.270. FIN.250 first asks respondents: "Now I am going to ask about the total combined income \{for you/of your family\} in \{last year in four digit format\}, including income from all sources we have just talked about, including wages, salaries, Social Security or retirement benefits, help from relatives and so forth. Can you tell me that amount before taxes?” If the respondent could not answer this question, they were then asked FIN. 260, which asked respondents to indicate if their total combined family income was above or below $\$ 20,000$. If the respondent could answer FIN.260, they were presented with a list of income groups (depending on their answer to FIN.260) and asked to choose the income group that best represented their family's total combined income in the previous year.

${ }^{15}$ In the family core section, the NHIS asks about children and special education. 
The poverty levels employed were the poverty levels published by the Census Bureau in 2001. The variables fm_size and fm_kids, which describe family size and number of family members under 18 years old, respectively, were also used in the construction of the income to poverty ratio, along with the imputed values for family income. Due to the imputation of data, no cases were classified as unknown, although a small number of cases were classified as 'undefinable” when the number of family members under 18 equaled the size of the family. ${ }^{16}$

Poverty statistics do not adjust for expenses that are the result of a health condition or a disability (e.g., personal assistance, equipment, medications, etc.). They also do not adjust for in-kind benefits, such as health insurance, food stamps, housing, transportation, child-care, etc. For both reasons, household income relative to the poverty line is substantially limited as an indicator of a household's poverty if the household contains a person with a disability.

Employment. We used four questions from the NHIS to determine employment status; see Table 1c for a specific description of those questions. In our analysis, persons are considered employed during the reference period if they answered that they were 'working for pay at a job or business' or 'with a job or business, but not at work' in the past week. Similarly, persons are considered employed 'sometime in the previous year' if they answered that they 'worked for pay at any time in the past year.' Lastly, persons are considered to be employed full-time year round if they answered that they worked at least 35 hours in the previous week, and indicated that they worked 12 months in the previous year at (at least) one job or business. We make the assumption that their full-time status in the previous week can be extended across all months in the previous year.

\section{Dissemination.}

Much of the data collected by the NHIS, and the subsequent analysis, is publicly available. Public use microdata have been released since 1969, and are available on CDROM. Current public use microdata files are available on the internet at

${ }^{16}$ See Proctor and Dalaker (2002) for a discussion of poverty thresholds. 
ftp://ftp.cdc.gov/pub/Health_Statistics/NCHS/Datasets/NHIS/2002/. In recent years, NCHS has released imputed income files to help account for the high proportion of nonresponse to questions relating to income. An assortment of other information, including survey questionnaires, flashcards, field representative manuals, input statements, and survey flowcharts, may also be downloaded from the NHIS website.

NCHS also produces a number of reports, based on data collected by the NHIS, which are available publicly; NHIS statistics and reports are published on the NCHS website, http://www.cdc.gov/nchs/nhis.htm. The NCHS Series 10 is devoted exclusively to reports compiled using data from the NHIS. Some of these reports concern a specific health issue, such as Attention Deficit Disorder and Learning Disability in the United States, while most are more general summaries of the health of the U.S. population, or subsets of the population. Detailed tables, including some state and regional statistics, may be downloaded at http://wonder.cdc.gov/data2010/, while customized tables may be produced using the U.S. Census' Ferret system, which can be found at http://dataferrett.census.gov.

\section{NHIS Description of Disability Population}

Disability can have different implications for employment and economic wellbeing at different ages. In this Guide, we first identify different age groups that reflect differences in activities. These age groups are: school-to-work transition-age persons between the ages of 18 and 24, working-age persons between the ages of 25 to 61, late working-age persons between the ages of 62 and 64, and retirement-age persons ages 65 and older. Our analysis of employment and economic well-being focuses on working-age persons between the ages of 25 and 61 .

Population estimates, prevalence estimates, and sample sizes from the NHIS are presented in Table 2. The rows are divided into sections for the population ages 18 and older and for each of the age categories. The columns identify the population without disabilities, those with disabilities, and those with each of the six disability types identified in the NHIS. The populations for the disability types sum to more than the total population with disabilities because individuals may report more than one disability type (i.e., the types are not mutually exclusive). 
The column labeled disability shows that in 2002 an estimated 43.1 million people ages 18 and older, or 20.9 percent of that population, reported a disability. Of the two participation restrictions that are asked of all people ages 18 and older, approximately 24.1 million people report an employment disability and 7.7 million report an IADL disability, for prevalence rates of 11.7 percent and 3.7 percent, respectively. Of the activity limitations and impairments that are asked for all people ages 18 and older, an estimated 3.6 million report an ADL disability, 6.3 million report a mental disability, 28.3 million report a physical disability and 7.0 million report a sensory disability. The prevalence rates are 1.8 percent, 3.0 percent, 13.8 percent and 3.4 percent, respectively.

Moving down to the age group categories, the group with largest number of people with disabilities, approximately 23.2 million, is the working age population between the ages of 25 and 61. The table also shows that the prevalence of disability increases with age from 7.8 percent of the population between the ages 18 to 24 to 47.5 percent of the population ages 65 and older. Finally, the table shows that the composition of disability type changes with age. Work limitation disabilities are the most prevalent of the six disability types for those ages 18 to 24, at 3.4 percent. Physical disabilities are the most prevalent of the six for the remaining age groups, at 10.5 percent for those aged 25-61, 23.3 percent for those aged 62 to 64, and 34.6 percent for those aged 65 and above.

The distribution of age, gender, race and education characteristics within each disability group are shown in Table 3. The first section of the table shows that the population without disabilities tends to be younger than the population with disabilities. The first column shows that a majority of the population without disabilities is age 44 or younger, with 15.5 percent of the population between ages 18 and 24, 20.7 percent between 25 and 34, and 23.3 percent between 35 and 44. In sum, 59.5 percent of adults without disabilities are between ages 18 and 44. The corresponding percentage of the population with disabilities in the 18 to 44 age range is only 26.1 percent (4.9 percent +7.1 percent+14.1 percent). Age differences are similar for the other disability categories in the NHIS, with the notable exception of mental disabilities; 25.1 percent of the 
population with a mental disability is between the ages of 18 and 34 and 23.3 percent between the ages of 35 and 44 .

The next section of the table shows differences by gender. More than half of the population without disabilities is female compared to 58.2 percent of the population with disabilities. Table 3 shows that the largest gender compositional differences are among those with IADL and physical disabilities, where 66.8 percent and 64.3 percent of the respective populations are women.

The NHIS data show the population with disabilities tends to have a greater share of white, black, and Native Americans, and a smaller share of Asians, compared to the population without disabilities. Approximately 82.6 percent of the population with disabilities is white, 12.4 percent is black, and 1.2 percent is Native American compared to corresponding percentages of 81.0 percent, 11.4 percent, and 0.6 percent of the population without disabilities. The population with disabilities that are Asian is 1.7 percent compared to the 4.1 percent of the population without disabilities who are Asian. The share of persons with disabilities who report Hispanic ethnicity is 7.9 percent, smaller than the 11.9 percent of the population without disabilities that reports Hispanic ethnicity.

Finally, Table 3 shows that the population with disabilities consists of a greater share of people with low levels of education compared to the population without disabilities. An estimated 27.3 percent of adults with disabilities have less than high school education and another 33.8 percent only has a high school education, while the corresponding numbers for those without disabilities are 13.5 percent and 28.4 percent respectively.

\section{NHIS Economic Well-Being and Employment Estimates}

In Table 4, we reported statistics concerning the economic well-being of the working-age population with and without disabilities. A significantly higher percentage of persons with disabilities reported family income beneath the poverty threshold than persons without disabilities; we estimate that 21.2 percent of the population with disabilities reported family income below the poverty threshold compared to 7.5 percent of the population without disabilities. The poverty rate is highest for those reporting an 
IADL disability, with an estimated 32.3 percent under the poverty threshold, while the lowest poverty rate for those with disabilities is for those with a sensory disability, with 20.7 percent below the poverty threshold. The poverty rate for persons with disabilities is significantly higher across demographic groups, with the poverty rate for persons with disabilities usually being two or three times that of those without disabilities.

We also found that a slightly higher proportion of women had family income beneath the poverty threshold, including those with disabilities. This relationship is found for all disability groups, except for those with sensory disabilities, where the difference was large; we found that men with sensory disabilities tended to have very low rates of poverty relative to men and women with other disabilities. There were also large differences in poverty rates by race. In general, we found that the lower poverty rates experienced by whites and Asians relative to other race groups persisted across disability categories. One exception to this trend is for those with IADL disabilities, where the poverty rates were almost equal for all racial groups except blacks (blacks with an IADL disability had poverty rates about double that of other groups).

In addition to poverty rates, we calculated median household income category by demographic group for those in the working-age population. (The NHIS does not allow for the calculation of median income other than the income range, or category, in which the median income falls.). In general, we found the median income category to be inversely proportional to the poverty rate for a demograph4ic group. It should be briefly noted here that the calculations presented in Table 4 are based in large part on data imputed by the NCHS because the NHIS response rate for questions relating to family income was low relative to other questions. As a result of the data imputation procedure, the variability of these estimates is high compared to other estimates in this User Guide. A more specific and technical description of these calculations is presented in Appendix A.

In Table 5, we report differences in employment characteristics by disability category. In general, those with disabilities are much less likely to be employed than those without disabilities. We estimate that 57.9 percent of persons with disabilities were employed sometime during the previous year, while 47.3 percent were employed 
sometime in the week prior to the interview and about 30 percent were employed fulltime during the course of the previous year. ${ }^{17}$

As expected, employment rates for men, both with and without disabilities, were higher than for women. The two exceptions to this pattern are the rate for women with an IADL disability who worked at some period in the past year, and full-time employment for women with a mental disability. We also found that, in general, the discrepancy between male and female employment patterns was more pronounced in the population without disabilities than within the population with disabilities.

Among those persons indicating a disability, those with sensory disabilities had the highest employment rates and those with IADL or ADL disabilities had the lowest. About 40 percent of those indicating a work limitation worked at some point during the previous year, but only 16.3 percent indicated that they were employed full-time over the course of the year.

Although there are similar employment rates for whites, Asians, and blacks without disabilities, the employment rates for whites and Asians with disabilities are higher than for blacks with disabilities. The full-time, full-year employment rates for whites, blacks and Asians was approximately 60 percent for all three groups in the population without disabilities. In the population with disabilities, however, about 40 percent of Asians, 30 percent of whites, and 20 percent of blacks were employed fulltime for all 12 months.

Employment rates increase with education across all groups and definitions of employment. The employment rates of the population without disabilities and with a high school education were slightly lower than the employment rates for the population without disabilities with some college education. This difference became more substantial for the population with disabilities; 28.8 percent of the population with disabilities with a high school diploma only was employed full-time for the entire year, compared to 38.1 percent of the population with disabilities with some college education.

\footnotetext{
${ }^{17}$ NHIS does not directly ask respondents if they were employed full-time during the previous year. We classify persons being in full-time employment over the past year if they indicated they worked 35 or more hours in the past week, and worked 12 months over the past year.
} 
We found the definition of work limitation to be a sufficient measure of employment disability. If the measure of work limitation was a perfect one, we would expect the employment rate for the group with disabilities who did not indicate a work limitation to equal the employment rate of the group without disabilities. Indeed, the employment rates for these groups were similar. According to estimates not reported in Table 4, for those working-age persons reporting disabilities other than a work limitation, we found that 68.1 percent reported working during the reference week, compared to 79.1 percent of the population without disabilities (29.8 percent of those with a work limitation worked in week prior to the survey). Similar patterns persisted when using alternate definitions of employment.

\section{Multiple Disabilities, Health Care, Insurance, and Health Conditions}

In Tables 6 (ages 18-64) and 7 (ages 65+), we report the percentage of persons with disabilities having a disability in each single or dual disability category. We found that of those in the working-age population with disabilities, a large proportion have only a work limitation or physical disability (17.9 and 23.8 percent, respectively); this trend also holds for the elderly. For the working-age population, over 90 percent of those with ADL and IADL disabilities had work limitations and over 70 percent had physical disabilities. For those with other disabilities, the likelihood of reporting a work limitation was much lower. About half of those with a sensory disability didn't report another type of disability, while only about 2 percent of those with an ADL or IADL disability only reported one disability type. Elderly persons with an ADL or IADL disability reported an employment disability with lower frequency than their working-age counterparts. Also, in every disability category except for ADL disability, the elderly were less likely to report only a single disability; multiple disabilities are more common among the elderly.

In Tables 8 (ages 18-64) and 9 (ages 65+), we report indicators of severe disability by disability category. We found that among working-age adults, about twothirds were designated as having an employment disability due to their response that they were 'unable to work,' while about one-third of the group was designated as having an employment disability due to their answer that they were limited in the kind or amount of work they could do. For those working-age adults without disabilities, a significant 
number (16.7 percent) have Kessler scores in the range of 4-12 - below the Kessler cutoff score for mental disability but more than the predominant category, 0 - 3. The proportion is much higher for those adults with disabilities other than a mental disability (the latter group is defined as those with a score of 13 or higher); at least one-third of the working-age adults with each of the five non-mental disabilities reported Kessler scores in the range of 4-12. For those working-age adults with a sensory disability, almost all reported some sort of hearing problem. About 10 percent reported being deaf, while about 78 percent reported having a lot of difficulty hearing without a hearing aid. ${ }^{18}$

The proportion of elderly people without disabilities reporting a Kessler score in the 4-12 range is about half the rate of working-age adults (8.94 versus 16.67 percent, respectively). In general, the Kessler scores of the elderly were lower than those for working-age adults. In addition, we found many of the elderly persons with sensory disabilities were classified as such due to the response that they had "a lot of difficulty hearing” without a hearing aid. In total, 10.0 percent of elderly persons reported "a lot of difficulty hearing” compared with just 1.4 percent of working-age adults.

We report statistics related to health status in Tables 10 (ages 18-64) and 11 (ages 65+). As expected, those with disabilities reported worse health status, as a whole, than those without disabilities. Among those with disabilities, those with sensory disabilities reported the best health status. For those reporting difficulty completing a physical activity, we also show their reported health conditions. The comparison between those with and without disabilities is somewhat misleading, as the "no disability" category includes only those who reported minor difficulty with a physical activity. We find that among those aged 18-64 reporting difficulty with a physical activity, common health conditions were arthritis, back or neck pain, bone injury, and depression. With the exception of depression, these health conditions were common among elderly persons who reported having difficulty with a physical activity. A relatively high proportion of this group also reported heart-related health problems. For working-age adults, persons

\footnotetext{
18 The question concerning blindness is a conditional one; only those who responded yes to the question "Do you have trouble seeing, even when wearing glasses or contact lenses?” were asked if they were blind. In 2002, 7.7 percent of working-age adults and 17.5 percent of elderly persons were asked the blindness question.
} 
with disabilities had significantly higher rates of body-mass index (BMI) in the overweight and obese categories. The distributions of BMI were similar across disability categories. For the elderly, the distributions of BMI categories vary less with disability status, although persons with disabilities are more likely to report BMIs that indicate moderate and severe obesity.

In Tables 12 and 13, we report statistics concerning health-care utilization by disability characteristic. We find that HMOs are more common as a usual source of health care for the elderly than for working-age adults (85.5 percent versus 79.0 percent), while working-age adults are more likely than the elderly to use the emergency room and clinics as a primary source of health care (17.6 percent versus 11.8 percent). 'Usual sources of health care' vary little by disability status.

For the working age population, those reporting disabilities are much more likely to report inability to afford counseling/mental health care in the year prior to the survey. Much of this difference seems to be driven by those with mental disabilities who experience extremely high rates of being unable to afford mental health care or counseling. More than 20 percent of adults with mental disabilities have been unable to afford mental health care in the year prior to the survey, compared with 2.3 percent of the total adult population.

For both working-age adults and the elderly, the percentage visiting the ER at least once in the year prior to the survey was about twice as high for those with disabilities as for those without disabilities. Those with ADL, IADL, and mental disabilities had higher rates of visiting the ER at least once compared to those with other disabilities. As expected, the percentage of persons with disabilities receiving at home care was much higher than people without disabilities. The percentage of elderly persons with disabilities receiving at-home care was about twice that of their counterparts without disabilities, while the percentage of working-age adults with disabilities receiving athome care was about four times that of working-age adults without disabilities. Both elderly and working-age people with disabilities are much heavier users of health care than those without disabilities. For instance, 70 percent of the elderly with disabilities and 65 percent of working-age adults with disabilities had four or more office visits in the 
previous year, compared to just 46 percent for the elderly without disabilities and 28 percent for working-age adults without disabilities. Over 50 percent of those with disabilities in both age groups had 10 or more home care visit during the year, compared to about 10 percent for those without disabilities in both age groups. A much higher rate of persons who needed health care, but did not receive it due to cost, was found for people with disabilities than for those without. The difference was most pronounced for working-age adults.

In Tables 14 and 15 we report health insurance statistics by disability category. We find the distributions of out-of-pocket expenditures on health care were similar for both the populations with and without disabilities, although those in the population with disabilities are somewhat more likely to spend high amounts (in excess of $\$ 1,000$ ) on health care. For the elderly, the distribution of sources of health care financing was similar for the populations with and without disabilities, with those without disabilities being somewhat more likely to be covered by private insurance only. For working-age adults, the distributions of sources of health care expenditures for persons with disabilities and those without disabilities were much more dissimilar than for the elderly population. About three quarters of working-age adults without disabilities reported being covered by private insurance only, compared to half of their counterparts with disabilities. Working-age persons with disabilities were more likely to be covered by public insurance, while the rates of uninsured were similar across populations with and without disabilities.

Tables 16 and 17 contain the statistics concerning the use of special equipment. Almost no working-age adults without disabilities require special equipment ( 0.50 percent), while 16.8 percent of the working-age population with disabilities reported using special equipment. For the elderly, the rates were 2.1 and 35.9 percent, respectively. For both working-age adults and the elderly, those with ADL and IADL disabilities had much higher rates of using special equipment than those with other types of disabilities. The rate of using a hearing aid for the elderly is significantly higher for the population with disabilities than for the population without disabilities. Almost 7 percent 
of elderly persons without disabilities reported using a hearing aid, compared with 21.1 percent of elderly persons who did have disabilities.

\section{Comparison to Other Data Sources}

The NHIS is one of several nationally representative datasets that are used to estimate the number of people with disabilities, the prevalence of persons with disabilities, the employment rate of persons with disabilities and the economic well-being of persons with disabilities. Different surveys use different methods to collect information on persons with disabilities and these differences can lead to differences in estimates. Some differences are as fundamental as how disability is defined. Many others are much more subtle (e.g., sampling methodology, interview methodology, structure of the questionnaire). This section shows how the NHIS estimates of the population compare to estimates from other nationally representative surveys.

The national datasets used for the comparison include: the 2002 American Community Survey (ACS), the 2000 Decennial Census (Census), the 2002 Current Population Survey (CPS), the 1994 National Health Interview Survey-Disability Supplement (NHIS-DS), the 2001 Panel Study of Income Dynamics (PSID) and the 2002 Survey of Income and Program Participation (SIPP). The year associated with each dataset represents the actual year that the survey was administered. Details on the methods used to collect information on persons with disabilities in each of these surveys may be found in the corresponding Cornell StatsRRTC User Guide.

Differences in estimates may be related to differences in the population over time. Thus, it is important to pay special attention to the survey year when comparing estimates across the surveys. The 2000 Decennial Census Long Form, for example, is representative of the year 2000. Changes in the population, the labor market and the economic environment between the year 2000 and the year 2002 can affect population estimates as well as estimates for prevalence, employment and economic well-being, and other variables.

Each comparison table defines disability as the presence of a participation restriction, an activity limitation, or an impairment. Some datasets are limited to identifying disabilities based upon a participation restriction. This is evident in the table 
by looking across the columns that identify the ICF disability concepts. A "NA" entry indicates that specific information on the particular ICF concept is not available in the survey. Disability is defined in these cases only based upon the information that is available in the survey. For example, the CPS only contains information on work limitation. The definition of disability in the CPS is therefore based solely on whether the person has a work limitation. In Figure 1, this definition captures a portion of persons who fall within the participation restriction circle.

The comparisons are made across the working-age population, only, for two reasons. First, most of the nationally representative surveys focus on the working-age population. Second, among the subset of surveys that identify children with disabilities, there are relatively large differences in the methods used to define and identify disability, and it is difficult to make meaningful comparisons. Further research on methods used to identify children with disabilities is needed.

\section{Population and Prevalence Estimates.}

The NHIS population and prevalence rate estimates are generally larger than estimates from datasets that use a smaller set of questions to estimate the size of the population with disabilities, but smaller than estimates from the one dataset that uses a larger set of questions. Table 18 shows differences across surveys in the size of the population with disabilities. The first section of the table shows the NHIS estimate of approximately 2.1 million persons between the ages of 18 and 24 with disabilities. It is smaller than the estimate of 2.4 million from the SIPP, which has a more extensive set of disability questions, but larger than the estimates from the 2003 ACS, Census 2000, the 2004 CPS, and the 2001 PSID, which use a smaller set of survey questions. The rest of the table shows comparisons for other age groups. The 2002 NHIS shows 23.2 million persons with disabilities in the 25 to 61 year age group. It is smaller than the 26.6 million SIPP estimate, but larger than the estimates from other surveys.

Table 19 shows estimates for prevalence rates. The first section of the table shows the 2002 NHIS disability prevalence rate estimate of 7.8 percent for the population between the ages of 18 and 24. It is lower than the SIPP estimate of 8.9 percent and higher than estimates based upon the 2003 ACS, Census 2000, the CPS and the PSID. 
For the working-age population between the ages of 25 and 61, the 2002 NHIS disability prevalence estimate is 16.7 percent, which is lower than the 18.7 percent reported in the SIPP, but higher than the 11.9 percent reported by the ACS, the 14.6 percent reported by the PSID, the 10.1 percent reported in the Census 2000 and the 8.4 percent reported in the CPS. For the population age 62 to 64, the NHIS data show a prevalence rate estimate of 32.5 percent. The NHIS estimate is lower than the SIPP estimate of 39.5 percent, is lower than the ACS estimate of 26.7 percent and the PSID estimate of 30.1 percent, and is higher than the Census 2000 estimate of 22.7 percent and the CPS estimate of 18.9 percent. For the population aged 18 to 64, the NHIS data shows a prevalence rate of 15.8 percent. Again, it is lower than the prevalence rate found in the SIPP, but higher than the prevalence rates found in other surveys.

\section{Employment Rate Estimates.}

The employment rate estimates in the NHIS fall in the middle of the range of estimates from national surveys; Table 20 illustrates these findings. The NHIS reference period measure shows an employment rate estimate of 83.3 percent for working-age persons without disabilities and 47.3 percent for persons with disabilities. For those without disabilities, the NHIS employment rate is slightly higher than estimates from other national surveys, other than the PSID. For those with disabilities, it is lower than the PSID estimate of 53.2 percent and is slightly lower than the SIPP estimate of 48.9 percent and is higher than the estimates from the ACS, Census 2000, and the CPS. The NHIS employment rate estimate using the 'some attachment to the labor force' measure for persons with disabilities is $\mathbf{5 7 . 9}$ percent. It is lower than estimates from the 2002 SIPP and the 2001 PSID, and larger than estimates from the 2003 ACS, 2000 Census, and the 2002 CPS. The NHIS full-time full-year estimate for persons with disabilities is 29.8 percent. It is lower than estimates from any other survey except for the PSID and SIPP estimates.

As these numbers indicate, employment rates tend to be highest in the surveys that show relatively high disability prevalence rates, and lowest in the surveys that show relatively low prevalence rates. Presumably this is because people with disabilities that are least likely to affect employment are also least likely to be identified as having 
disabilities in surveys that include only a few disability questions. The latter invariably include work limitation questions, which, by design, are the most likely to capture those who are not working because of a disability. This same phenomenon is observed for measures of economic well-being.

\section{Economic Well-Being Estimates.}

The poverty rate estimates from the 2002 NHIS are in the middle of the range of estimates from other surveys; Table 21 compares poverty rate estimates across the datasets. The NHIS poverty rate estimate for the working-age population without disabilities is 7.5 percent. This estimate is higher than the PSID and SIPP estimates, and lower than estimates from other datasets. The NHIS poverty rate estimate for those with disabilities is 21.2 percent. This rate is lower than the poverty rate estimates in the ACS, CPS and Census 2000, and higher than the poverty rate estimates in the PSID and SIPP. The remaining columns show poverty rates across disability datasets by the disability type.

Because family income is reported as a range, the median income measures in the NHIS cannot be directly compared to those derived from other surveys. The trends are similar, however, with significant differences in family (or household) income between the populations with and without disabilities.

\section{Summary and Conclusion}

This Guide describes the information on the population with disabilities from the 2002 National Health Interview Survey (NHIS). It begins with a description of the ICF conceptual model of disability. The ICF provides a framework that may be used to assess the disability information in the NHIS as well as the disability information in other surveys.

The Guide then presents an overview of the survey methodology and definitions. The design of the NHIS provides several advantages over other data collection efforts. The NHIS contains the largest amount of information on health-related data of all the major surveys, including particularly unique and extensive data on health insurance, health care access and utilization, health status, health-related conditions and health 
behaviors. The NHIS also contains a broad set of data on disability-related topics, including the limitation of functional activities, mental health questions used to measure psychological distress, limitations in sensory ability, and limitations in work ability. Moreover, the NHIS provides data for those persons who indicated a limitation to a functional activity about the source or condition of their functional limitation.

Additional strengths of the NHIS include its continuous administration over the past five decades, which allows for the comparison of health trends, and the specialized information derived from supplemental survey questions.

We illustrate the utility of the NHIS with estimates based on the NHIS Public Use Microdata Sample for the population with disabilities, including: the size of the population, the prevalence rate, the demographic composition, the employment rate and economic well-being measures, all by disability type. At the national level, the NHIS estimates show that there are approximately 43 million adults (age 18 and older) with disabilities in the non-institutionalized U. S. population, 20.9 percent of the adult population. For those age 18 to 64 only, the estimate is 27 million persons, or 18.8 percent of the population. Compared to the population without disabilities, the population with disabilities is older, more likely to be of African American and Native American decent, and more likely to have educational achievement below the high school level. The NHIS data also show significant differences in health status, health care utilization, and characteristics of health insurance by disability status.

Finally, this User Guide compares estimates from the NHIS to other national surveys that collect information on the population with disabilities. The comparisons show that surveys that use a larger number of questions to identify the population with disabilities tend to have higher estimates of the population with disabilities, higher disability prevalence estimates, higher disability employment rates, higher household median income levels for persons with disabilities and lower poverty rates for persons with disabilities. Due to the large number of questions used to identify disabilities, estimates from the NHIS fall within the upper range of the range of estimates for the characteristics used in this Guide. 
In conclusion, while there are limitations to the disability data collected in the NHIS, the NHIS provides very substantial information about the numbers and characteristics of persons with disabilities in the U.S. The extensive data on health status, health care utilization, and health insurance in the NHIS is particularly valuable, because it captures information that is not captured in other major surveys. The use of the NHIS to monitor the status of the population with disabilities and to provide insight into the environment that may influence progress will be an important component of the nation's efforts to reach the goals of full participation, independent living and economic selfsufficiency for the population with disabilities. 
References

Altman, Barbara M. 2001. "Disability Definitions, Models, Classification Schemes, and Applications.” in Gary L. Albrecht, Katherine D. Seelman, and Michael Bury, eds. Handbook of Disability Studies. Sage Publications: Thousand Oaks CA.

Fowler, Floyd J. 1996. "The Redesign of the National Health Interview Survey.” Public Health Reports 111(6): 509-511.

Kessler, R.C. et al. 2002. "Short Screening Scales to Monitor Population Prevalences and Trends in Non-Specific Psychological Distress.” Psychological Medicine 32: 959976.

Kessler, R.C. et al. 2003. "Screening for Serious Mental Illness in the General Population.” Archives of General Psychiatry 60(2): 184-189.

Jette, Alan M. and Elizabeth Badley. 2000. “Conceptual Issues in the Measurement of Work Disability," in Nancy Mathiowetz and Gooloo Wunderlich eds. Survey of Measurement of Work Disability: Summary of a Workshop. National Academy Press: Washington D.C.

Mathiowitz, Nancy. 2000. "Methodological Issues in the Measurement of Work Disability,” in Nancy Mathiowetz and Gooloo Wunderlich eds. Survey of Measurement of Work Disability: Summary of a Workshop. National Academy Press: Washington D.C.

Nagi, Saad. 1965. “Some Conceptual Issues in Disability and Rehabilitation,” in Martin B. Sussman ed. Sociology and Rehabilitation. American Sociological Association: Washington, DC.

Nagi, Saad. 1976. “An Epidemiology of Disability Among Adults in the United States,” Milbank Memorial Fund Quarterly: Health and Society vol. 54 p. 439-467.

National Center for Health Statistics. 1999. "National Health Interview Survey: Research for the 1995-2004 Redesign.” Vital and Health Statistics Series 2, no. 126.

Available from the website (www.cdc.gov/nchs/nhis.htm). July.

National Center for Health Statistics. 2000. "Design and Estimation for the National Health Interview Survey, 1995-2004.” Vital and Health Statistics Series 2, no. 130. June. Available from the website (www.cdc.gov/nchs/nhis.htm).

National Center for Health Statistics. 2003. “NHIS Survey Description: 2002 National Health Interview Survey (NHIS) Public Use Data Release." (www.cdc.gov/nchs/nhis.htm). December. 
National Center for Health Statistics. 2005. "Multiple Imputation of Family Income and Personal Earnings in the National Health Interview Survey: Methods and Examples.” Available from the website (www.cdc.gov/nchs/nhis.htm). May.

Proctor, Bernadette D. and Joseph Dalaker. 2002. "Poverty in the United States: 2001.” U.S. Census Bureau, Current Population Reports. P60-219. U.S. Government Printing Office: Washington, D.C.

World Health Organization. 2001. International Classification of Disability, Health and Functioning. World Health Organization: Geneva. 
Tables

Table 1a. Disability Definitions from the 2002 NHIS

\begin{tabular}{ll}
\hline NHIS Term & Question \\
\hline & FHS.070: Because of a physical, mental, or emotional \\
& problem $\{$ do/does $\}$ you/anyone in the family $\}$ need the
\end{tabular}

ADL problem $\{$ do/does $\}$ you/anyone in the family\} need the help of other persons with PERSONAL CARE NEEDS, such as eating, bathing, dressing, or getting around

Classified as disabled if respondent inside the home?

FHS.150: Because of a physical, mental, or emotional problem $\{$ do/does $\}$ you/anyone in the family\} need the

IADL help of other persons in handling ROUTINE NEEDS, such as everyday household chores, doing unnecessary business, shopping, or getting around for other purposes?

FHS.170: Does a physical, mental, or emotional Work Limitation problem NOW keep \{you/anyone in the family/any of these family members (READ NAMES) from working at a job or business?

Notes

answers 'yes' to this question.

Classified as disabled if respondent answers 'yes' to this question.

Classified as having a work limitation if answering in the affirmative to either question.

FHS.190: \{Are/ (other than the persons mentioned), are any of these family members \{you/(READ ADULT NAMES) $\}$ limited in the kind OR amount of work $\{$ you/they $\}$ can do because of a physical, mental, or emotional problem?

ACN.420: Which statement best describes your hearing Classified as having a sensory Sensory without a hearing aid: good, a little trouble, a lot of trouble, deaf?

impairment if individual indicates they have 'a lot of trouble' or are 'deaf'

Classified as having a sensory

ACN.440: Are you blind or unable to see at all? impairment if individual indicates they are blind.

Classified as having a physical disability if respondent answers 'can't do at all' or 'very difficult' to any question.

a. Walk a quarter of a mile-about 3 city blocks?

b. Walk up 10 steps without resting?

c. Stand or be on your feet for about 2 hours?

d. Sit for about 2 hours?

e. Stoop, bend, or kneel?

f. Reach over your head?

AHS.141: By yourself, and without the use of special equipment, how difficult is it for you to....

a. Use your fingers to grasp or handle small objects?

b. Lift or carry something as heavy as 10 pounds such as a bag full of groceries?

c. Push or pull large objects like a living room chair? 
Table 1a (continued). Disability Definitions from the 2002 NHIS

\begin{tabular}{lll}
\hline NHIS Term & Question & Notes \\
\hline & & $\begin{array}{l}\text { Responses were assigned the } \\
\text { following point value: (0) None of the } \\
\text { time/Don't know/refused (1) A little of } \\
\text { the time (2) some of the time (3) Most } \\
\text { of the time (4) All of the time. } \\
\text { Individuals with a combined score of } \\
\text { CAN.471: During the PAST 30 DAYS how often did } \\
\text { you feel.... }\end{array}$ \\
& $\begin{array}{l}\text { 13 or greater were classified, under } \\
\text { the Kessler Index, as having a mental } \\
\text { disability. }\end{array}$ \\
& \\
a. So sad nothing could cheer you up? & \\
b. Nervous? & \\
c. Restless or fidgety? & \\
d. Hopeless? & \\
e. That everything was an effort? & \\
f. Worthless? &
\end{tabular}




\begin{tabular}{|c|c|}
\hline NHIS Term & Question \\
\hline Gender & HHC.110: $\{$ Are/is $\}$ \{you/name $\}$ male or female? \\
\hline Age & $\begin{array}{l}\text { HHc.120: What is }\{\text { name/you }\} \text { age and date of birth? Please give month, } \\
\text { day, and year for date of birth. Note: If age given does not correspond to } \\
\text { the age calculated from the date of birth, respondents are asked to verify } \\
\text { information. }\end{array}$ \\
\hline Race & $\begin{array}{l}\text { HHC.200: What race }\{\text { do/does }\} \text { \{you/names }\} \text { consider } \\
\text { \{yourself/himself/herself }\} \text { to be? Please select } 1 \text { or more of these } \\
\text { categories. Possible responses include: White; Black/African American; } \\
\text { Indian (American); Alaska Native; Native Hawaiian; Guamanian, } \\
\text { Samoan, Other Pacific Islander; Asian Indian; Chinese; Filipino; } \\
\text { Japanese; Korean; Vietnamese; Other Asian; Some other race; Refused; } \\
\text { Don't know. If respondents answered multiple categories to HHC.200, } \\
\text { they were asked HHC.220: Which one of these groups, that is (read } \\
\text { groups) would you say BEST represents \{your/name's\} race? }\end{array}$ \\
\hline Race Recode & $\begin{array}{l}\text { NHIS employs a series of race recodes, including the recode into variable } \\
\text { 'mracrp_i', which recodes race into the following categories: White; } \\
\text { Black/African American; Indian (American), Alaska Native; Asian } \\
\text { Indian; Chinese; Filipino; other Asian; other race; multiple race. In this } \\
\text { guide, we combined the Asian categories into a single category. }\end{array}$ \\
\hline Hispanic Origin & $\begin{array}{l}\text { HHC.170: }\{\text { Do/does }\} \text { you/names }\} \text { consider }\{\text { yourself/himself/herself }\} \text { to } \\
\text { be Hispanic or Latino? }\end{array}$ \\
\hline Education & $\begin{array}{l}\text { FSD.010: What is the highest level of school }\{\text { you/subject name }\} \\
\text { \{have/has }\} \text { completed or the highest degree }\{\text { you/subject name } \\
\text { \{have/has }\} \text { received? }\end{array}$ \\
\hline Education Recode: & Those answering never attended/kindergarten only, 1st grade through \\
\hline Less than High School & 12th grade/no diploma were coded as 'less than high school.' \\
\hline High School & $\begin{array}{l}\text { Those answering GED equivalent or high school diploma were coded as } \\
\text { 'high school.' }\end{array}$ \\
\hline Greater than High School & $\begin{array}{l}\text { Those answering some college, no degree; associate degree, bachelor's } \\
\text { degree, master's degree, professional school degree, or doctoral degree } \\
\text { were coded as 'greater than high school.' }\end{array}$ \\
\hline
\end{tabular}


Table 1c. Employment Definitions from the 2002 NHIS

\begin{tabular}{|c|c|}
\hline NHIS Term & Question \\
\hline \multirow[t]{4}{*}{ Employment Status Questions } & $\begin{array}{l}\text { FSD.050: Which of the following }\{\text { were/was }\} \text { \{you/subject name }\} \text { doing last } \\
\text { week? }\end{array}$ \\
\hline & $\begin{array}{l}\text { FSD.100: Did }\{\text { you/he/she }\} \text { work for pay at any time in }\{\text { last year in } 4 \text { digit } \\
\text { format }\} \text { ? }\end{array}$ \\
\hline & $\begin{array}{l}\text { FSD.070: How many hours did \{you/subject name }\} \text { work LAST WEEK at all } \\
\text { jobs or businesses? OR How many hours }\{\text { do/does }\{\text { you/subject name } \\
\text { USUALLY work at all jobs or businesses? }\end{array}$ \\
\hline & $\begin{array}{l}\text { FSD.110: How many months in }\{\text { last year in } 4 \text { digit format }\} \text { did }\{\text { you/subject } \\
\text { name }\} \text { have at least one job or business? }\end{array}$ \\
\hline \multicolumn{2}{|l|}{ Employment Definitions } \\
\hline Employed: Reference Period & $\begin{array}{l}\text { Those answering 'working for pay at a job or business' or 'with a job or } \\
\text { business, but not at work' to FSD. } 050 \text { were classified as employed during the } \\
\text { reference period. }\end{array}$ \\
\hline $\begin{array}{l}\text { Employed: } \\
\text { Sometime in Previous Year }\end{array}$ & $\begin{array}{l}\text { Those answering 'yes' to FSD. } 100 \text { were classified as employed sometime in } \\
\text { the previous year. }\end{array}$ \\
\hline Employed: & Those answering 35 or greater to FSD.070 and 12 to FSD. 110 were classified \\
\hline Full-time year round & \\
\hline
\end{tabular}




\begin{tabular}{ll}
\hline NHIS Term & Question \\
\hline & $\begin{array}{l}\text { FIN.250: Now I'm going to ask about the total combined income ffor you/of your } \\
\text { family\}, including income from all sources we have talked about including wages, } \\
\text { salaries, Social Security or retirement benefits, help from relatives and so forth. } \\
\text { Can you tell me the amount before taxes? Note: Respondents who don't know or } \\
\text { refused to answer this question were then asked if family income was greater than } \\
\text { or less than \$20,000. If a respondent answered this question, they were then shown } \\
\text { a flashcard listing a several income categories and were asked to select the } \\
\text { category that best represented their total family income. See text for description of } \\
\text { imputation procedures and issues. }\end{array}$ \\
$\begin{array}{ll}\text { Poverty } & \begin{array}{l}\text { A ratio of total family income to the poverty threshold was constructed using total } \\
\text { household size, in addition to number of children in the household. The variable }\end{array} \\
\text { Household Size } & \text { 'rat_cati' reports a poverty gradient consisting of 14 ranges. See Poverty in the } \\
\text { Income } & \text { United States, 2001;.U.S. Census Bureau. } \\
\text { Household } & \text { NHIS only collects information on family income. } \\
\text { Income } & \text { NA }\end{array}$ \\
\hline
\end{tabular}




\section{Disability Participation Restriction Activity \\ Limitation \\ Impairment}

$\begin{array}{cccccccc}\text { No } & \begin{array}{c}\text { At least } 1 \\ \text { of the } 6\end{array} & \begin{array}{c}\text { Work } \\ \text { Limitation }\end{array} & \text { IADLs } & \text { ADLs } & \text { Mental } & \text { Physical } & \text { Sensory } \\ \text { Disability } & & & & \end{array}$

\section{All, Age 18-99}

Population Estimate 162,769,202

43,055,893 24,054,533 7,704,846 3,628,616 6,250,523 28,318,682 7,011,741

Prevalence Rate

79.1

20.9

11.7

3.7

1.8

3.0

13.8

3.4

Sample Size

$23,872 \quad 7,172$

4,171

1,443

615

1,030

4,774

1,138

\section{Ages 5 to 17}

Population Estimate

$\begin{array}{ll}\text { NA } & \text { NA } \\ \text { NA } & \text { NA } \\ \text { NA } & \text { NA }\end{array}$

NA

NA

NA

NA

NA

NA

Prevalence Rate

NA

NA

NA

NA

NA

NA

NA

Sample Size

NA

NA

NA

NA

NA

NA

NA

\section{Ages 18 to 24}

Population Estimate 25,225,949

2,126,359

927,148

228,196

147,650

786,056

$859,096 \quad 78,295$

Prevalence Rate

92.2

7.8

3.4

0.8

0.5

2.9

3.1

0.3

Sample Size

3087

273

121

31

18

100

107

15

\section{Ages 25 to 61}

Population Estimate 115,934,131

$23,192,261$

$13,725,573$

$3,169,051$

$1,350,820$

$4,627,949$

$14,545,9092,730,316$

Prevalence Rate

83.3

16.7

9.9

2.3

1.0

3.3

10.5

2.0

Sample Size

$17,166 \quad 3,661$

2,269

538

226

767

2,293

404

\section{Ages 62 to 64}

Population Estimate

$4,239,825$

$2,045,373 \quad 1,281,364 \quad 300,042$

127,714

144,240

$1,466,133 \quad 310,628$

Prevalence Rate

67.5

32.5

20.4

4.8

2.0

2.3

23.3

4.9

Sample Size

647

350

232

60

25

32

249

44

\section{Ages 65 and older}

Population Estimate $\quad 17,369,301 \quad 15,691,900 \quad$ 8,110,448 $\quad$ 4,007,557 2,002,432 $\quad$ 692,278 $\quad$ 11,447,544 3,892,502

Prevalence Rate

$52.5 \quad 47.5$

24.5

12.1

6.1

2.1

34.6

11.8

Sample Size

2,972

2,888

1,549

814

346

131

2,125

675

Source: Author's calculations from 2002 National Health Interview Survey (NHIS) 


\begin{tabular}{|c|c|c|c|c|c|c|c|c|}
\hline \multirow[b]{2}{*}{ Characteristic } & \multirow[b]{2}{*}{$\begin{array}{c}\text { No } \\
\text { Disability } \\
\end{array}$} & \multirow{2}{*}{$\begin{array}{c}\text { Disability } \\
\text { At least } 1 \\
\text { of the } 6 \\
\end{array}$} & \multicolumn{3}{|c|}{ Participation Restriction Activity } & \multicolumn{3}{|c|}{ Impairment } \\
\hline & & & $\begin{array}{c}\text { Work } \\
\text { Limitation } \\
\end{array}$ & IADLs & ADLs & Mental & Physical & Sensory \\
\hline \multicolumn{9}{|l|}{ Age } \\
\hline$\% 18$ to 24 & 15.5 & 4.9 & 3.9 & 3.0 & 4.1 & 12.6 & 3.0 & 1.1 \\
\hline$\% 25$ to 34 & 20.7 & 7.1 & 6.4 & 3.8 & 4.0 & 12.5 & 4.9 & 4.6 \\
\hline$\% 35$ to 44 & 23.3 & 14.1 & 14.3 & 11.3 & 8.8 & 23.3 & 11.8 & 10.1 \\
\hline$\% 45$ to 54 & 18.9 & 19.2 & 21.4 & 14.7 & 14.3 & 28.4 & 20.0 & 12.0 \\
\hline$\% 55$ to 64 & 10.9 & 18.2 & 20.3 & 15.2 & 13.7 & 12.2 & 19.8 & 16.6 \\
\hline$\% 65$ to 74 & 6.8 & 15.6 & 14.8 & 14.4 & 13.3 & 5.7 & 16.8 & 19.5 \\
\hline$\% 75$ to 84 & 3.3 & 15.3 & 13.5 & 22.4 & 25.3 & 3.9 & 17.3 & 23.5 \\
\hline$\% 85$ or older & 0.5 & 5.5 & 5.5 & 15.2 & 16.6 & 1.5 & 6.3 & 12.5 \\
\hline \multicolumn{9}{|l|}{ Gender } \\
\hline \% Male & 49.6 & 41.8 & 45.4 & 33.2 & 40.7 & 37.7 & 35.7 & 57.5 \\
\hline$\%$ Female & 50.4 & 58.2 & 54.6 & 66.8 & 59.3 & 62.3 & 64.3 & 42.5 \\
\hline \multicolumn{9}{|l|}{ Race } \\
\hline \% White & 81.0 & 82.6 & 81.8 & 80.2 & 76.1 & 78.7 & 82.7 & 89.6 \\
\hline$\%$ Black & 11.4 & 12.4 & 13.6 & 14.0 & 16.6 & 14.2 & 12.4 & 5.9 \\
\hline \% Native American & 0.6 & 1.2 & 1.3 & 1.4 & 1.1 & 1.6 & 1.2 & 2.0 \\
\hline$\%$ Asian & 4.1 & 1.7 & 1.5 & 2.2 & 3.2 & 1.8 & 1.7 & 1.4 \\
\hline \% Other & 2.7 & 2.0 & 1.7 & 1.9 & 2.6 & 3.5 & 1.9 & 1.2 \\
\hline \% Multiple Races & 0.2 & 0.1 & 0.1 & 0.2 & 0.3 & 0.3 & 0.1 & 0.0 \\
\hline \multicolumn{9}{|l|}{ Ethnicity } \\
\hline \% Hispanic & 11.9 & 7.9 & 7.3 & 7.8 & 9.2 & 12.3 & 7.4 & 5.2 \\
\hline \multicolumn{9}{|l|}{ Education } \\
\hline \% Less than High School & 13.5 & 27.3 & 29.5 & 35.4 & 34.9 & 29.5 & 28.7 & 27.3 \\
\hline \% High School/GED & 28.4 & 33.8 & 34.0 & 30.4 & 31.2 & 36.4 & 33.8 & 33.6 \\
\hline \% Some College & 29.9 & 24.2 & 23.4 & 21.3 & 19.1 & 23.2 & 23.9 & 20.8 \\
\hline $\begin{array}{l}\text { \% Four Year College } \\
\text { Graduate or more }\end{array}$ & 27.0 & 13.3 & 11.4 & 9.4 & 10.9 & 10.3 & 12.2 & 16.5 \\
\hline \% Refused/Don't Know & 1.2 & 1.4 & 1.7 & 3.5 & 3.9 & 0.5 & 1.4 & 1.7 \\
\hline Total & 79.1 & 20.9 & 11.7 & 3.7 & 1.8 & 3.0 & 13.8 & 3.4 \\
\hline
\end{tabular}

Source: Author's calculations from 2002 National Health Interview Survey (NHIS) 


\begin{tabular}{|c|c|c|c|c|c|c|c|c|}
\hline & \multirow[b]{2}{*}{ No Disability } & \multirow{2}{*}{$\begin{array}{c}\text { Disability } \\
\begin{array}{c}\text { At least } 1 \text { of } \\
\text { the } 6\end{array}\end{array}$} & \multicolumn{2}{|c|}{ Participation Restriction } & \multirow{2}{*}{$\begin{array}{c}\begin{array}{c}\text { Activity } \\
\text { Limitation }\end{array} \\
\text { ADLs }\end{array}$} & \multicolumn{3}{|c|}{ Impairment } \\
\hline & & & $\begin{array}{l}\text { Work } \\
\text { Limitation }\end{array}$ & IADLs & & Mental & Physical & Sensory \\
\hline \multicolumn{9}{|l|}{ All } \\
\hline \% Below Poverty Line & 7.5 & 21.2 & 26.5 & 32.3 & 30.1 & 29.8 & 22.1 & 20.7 \\
\hline Median Household Income & $\begin{array}{l}\$ 55,000- \\
\$ 64,000\end{array}$ & $\begin{array}{l}\$ 25,000- \\
\$ 34,999\end{array}$ & $\begin{array}{c}\$ 25,000- \\
\$ 34,999\end{array}$ & $\begin{array}{l}\$ 20,000- \\
\$ 24,999\end{array}$ & $\begin{array}{l}\$ 20,000- \\
\$ 24,999\end{array}$ & $\begin{array}{l}\$ 20,000- \\
\$ 24,999\end{array}$ & $\begin{array}{c}\$ 25,000- \\
\$ 34,999\end{array}$ & $\begin{array}{l}\$ 35,000- \\
\$ 44,999\end{array}$ \\
\hline \multicolumn{9}{|l|}{ Men } \\
\hline \% Below Poverty Line & 6.5 & 18.9 & 24.0 & 31.7 & 28.6 & 25.2 & 20.6 & 14.0 \\
\hline Median Household Income & $\begin{array}{c}\$ 55,000- \\
\$ 64,000\end{array}$ & $\begin{array}{c}\$ 25,000- \\
\$ 34,999\end{array}$ & $\begin{array}{c}\$ 25,000- \\
\$ 34,999\end{array}$ & $\begin{array}{l}\$ 20,000- \\
\$ 24,999\end{array}$ & $\begin{array}{l}\$ 20,000- \\
\$ 24,999\end{array}$ & $\begin{array}{l}\$ 25,000- \\
\$ 34,999\end{array}$ & $\begin{array}{c}\$ 25,000- \\
\$ 34,999\end{array}$ & $\begin{array}{l}\$ 35,000- \\
\$ 44,999\end{array}$ \\
\hline \multicolumn{9}{|l|}{ Women } \\
\hline \% Below Poverty Line & 8.5 & 23.0 & 28.7 & 32.7 & 31.6 & 32.7 & 23.0 & 30.8 \\
\hline Median Household Income & $\begin{array}{c}\$ 55,000- \\
\$ 64,000\end{array}$ & $\begin{array}{c}\$ 25,000- \\
\$ 34,999\end{array}$ & $\begin{array}{c}\$ 25,000- \\
\$ 34,999\end{array}$ & $\begin{array}{l}\$ 20,000- \\
\$ 24,999\end{array}$ & $\begin{array}{l}\$ 20,000- \\
\$ 24,999\end{array}$ & $\begin{array}{l}\$ 20,000- \\
\$ 24,999\end{array}$ & $\begin{array}{c}\$ 25,000- \\
\$ 34,999\end{array}$ & $\begin{array}{l}\$ 25,000- \\
\$ 34,999\end{array}$ \\
\hline \multicolumn{9}{|l|}{ White } \\
\hline \% Below Poverty Line & 6.0 & 18.0 & 23.5 & 28.9 & 25.2 & 27.7 & 18.6 & 17.0 \\
\hline Median Household Income & $\begin{array}{c}\$ 55,000- \\
\$ 64,000\end{array}$ & $\begin{array}{c}\$ 35,000- \\
\$ 44,999\end{array}$ & $\begin{array}{c}\$ 25,000- \\
\$ 34,999\end{array}$ & $\begin{array}{l}\$ 20,000- \\
\$ 24,999\end{array}$ & $\begin{array}{c}\$ 20,000- \\
\$ 24,999\end{array}$ & $\begin{array}{l}\$ 25,000- \\
\$ 34,999\end{array}$ & $\begin{array}{c}\$ 35,000- \\
\$ 44,999\end{array}$ & $\begin{array}{l}\$ 35,000- \\
\$ 44,999\end{array}$ \\
\hline \multicolumn{9}{|l|}{ Black } \\
\hline \% Below Poverty Line & 14.7 & 35.9 & 41.2 & 50.4 & 42.8 & 37.0 & 37.3 & 39.4 \\
\hline Median Household Income & $\begin{array}{c}\$ 35,000- \\
\$ 44,999\end{array}$ & $\begin{array}{l}\$ 20,000- \\
\$ 24,999\end{array}$ & $\begin{array}{c}\$ 15,000- \\
\$ 19,999\end{array}$ & $\begin{array}{l}\$ 10,000- \\
\$ 14,999\end{array}$ & $\begin{array}{l}\$ 10,000- \\
\$ 14,999\end{array}$ & $\begin{array}{l}\$ 20,000- \\
\$ 24,999\end{array}$ & $\begin{array}{c}\$ 15,000- \\
\$ 19,999\end{array}$ & $\begin{array}{l}\$ 15,000- \\
\$ 19,999\end{array}$ \\
\hline \multicolumn{9}{|l|}{ Hispanic } \\
\hline \% Below Poverty Line & 16.9 & 31.2 & 37.7 & 28.6 & 36.3 & 43.0 & 31.9 & 28.2 \\
\hline Median Household Income & $\begin{array}{c}\$ 35,000- \\
\$ 44,999\end{array}$ & $\begin{array}{c}\$ 25,000- \\
\$ 34,999\end{array}$ & $\begin{array}{c}\$ 20,000- \\
\$ 24,999\end{array}$ & $\begin{array}{l}\$ 25,000- \\
\$ 34,999\end{array}$ & $\begin{array}{c}\$ 25,000- \\
\$ 34,999\end{array}$ & $\begin{array}{l}\$ 20,000- \\
\$ 24,999\end{array}$ & $\begin{array}{c}\$ 25,000- \\
\$ 34,999\end{array}$ & $\begin{array}{l}\$ 35,000- \\
\$ 44,999\end{array}$ \\
\hline \multicolumn{9}{|l|}{ Native American } \\
\hline \% Below Poverty Line & 14.3 & 39.2 & 38.8 & 28.8 & 58.1 & 50.1 & 40.8 & 55.9 \\
\hline Median Household Income & $\begin{array}{l}\$ 25,000- \\
\$ 34,999 \\
\end{array}$ & $\begin{array}{c}\$ 15,000- \\
\$ 19,999\end{array}$ & $\begin{array}{c}\$ 10,000- \\
\$ 14,999\end{array}$ & $\begin{array}{l}\$ 15,000- \\
\$ 19,999\end{array}$ & $\begin{array}{l}\$ 5,000- \\
\$ 9,999\end{array}$ & $\begin{array}{l}\$ 10,000- \\
\$ 14,999\end{array}$ & $\begin{array}{c}\$ 15,000- \\
\$ 19,999\end{array}$ & $\begin{array}{l}\$ 10,000- \\
\$ 14,999\end{array}$ \\
\hline
\end{tabular}


Table 4 (continued). Economic Well Being Measures, Ages 25 to 61

\begin{tabular}{|c|c|c|c|c|c|c|c|c|}
\hline & \multirow[b]{2}{*}{ No Disability } & \multirow{2}{*}{$\begin{array}{c}\text { Disability } \\
\begin{array}{c}\text { At least } 1 \text { of } \\
\text { the } 6\end{array} \\
\end{array}$} & \multicolumn{2}{|c|}{ Participation Restriction } & \multicolumn{2}{|l|}{$\begin{array}{c}\text { Activity } \\
\text { Limitation }\end{array}$} & \multicolumn{2}{|c|}{ Impairment } \\
\hline & & & Limitation & IADLs & ADLs & Mental & Physical & Sensory \\
\hline \multicolumn{9}{|l|}{ Asian } \\
\hline \% Below Poverty Line & 10.4 & 19.2 & 16.9 & 24.5 & 38.2 & 22.4 & 24.9 & 24.5 \\
\hline Median Household Income & $\begin{array}{c}\$ 55,000- \\
\$ 64,000\end{array}$ & $\begin{array}{l}\$ 45,000- \\
\$ 54,000\end{array}$ & $\begin{array}{c}\$ 45,000- \\
\$ 54,000\end{array}$ & $\begin{array}{c}\$ 25,000- \\
\$ 34,999\end{array}$ & $\begin{array}{c}\$ 25,000- \\
\$ 34,999\end{array}$ & $\begin{array}{c}\$ 55,000- \\
\$ 64,000\end{array}$ & $\begin{array}{c}\$ 35,000- \\
\$ 44,999\end{array}$ & $\begin{array}{l}\$ 55,000 \\
\$ 64,000\end{array}$ \\
\hline \multicolumn{9}{|l|}{ LT High School } \\
\hline \% Below Poverty Line & 23.3 & 41.5 & 46.5 & 53.2 & 43.4 & 46.0 & 44.4 & 38.0 \\
\hline Median Household Income & $\begin{array}{l}\$ 25,000- \\
\$ 34,999\end{array}$ & $\begin{array}{l}\$ 15,000- \\
\$ 19,999\end{array}$ & $\begin{array}{c}\$ 15,000- \\
\$ 19,999\end{array}$ & $\begin{array}{l}\$ 10,000- \\
\$ 14,999\end{array}$ & $\begin{array}{l}\$ 10,000- \\
\$ 14,999\end{array}$ & $\begin{array}{l}\$ 15,000- \\
\$ 19,999\end{array}$ & $\begin{array}{c}\$ 15,000- \\
\$ 19,999\end{array}$ & $\begin{array}{l}\$ 20,000- \\
\$ 24,999\end{array}$ \\
\hline \multicolumn{9}{|l|}{ High School } \\
\hline \% Below Poverty Line & 9.2 & 19.9 & 23.4 & 28.2 & 34.3 & 30.2 & 19.8 & 20.8 \\
\hline Median Household Income & $\begin{array}{l}\$ 45,000- \\
\$ 54,000\end{array}$ & $\begin{array}{l}\$ 25,000- \\
\$ 34,999\end{array}$ & $\begin{array}{c}\$ 25,000- \\
\$ 34,999\end{array}$ & $\begin{array}{l}\$ 20,000- \\
\$ 24,999\end{array}$ & $\begin{array}{l}\$ 15,000- \\
\$ 19,999\end{array}$ & $\begin{array}{l}\$ 20,000- \\
\$ 24,999\end{array}$ & $\begin{array}{c}\$ 25,000- \\
\$ 34,999\end{array}$ & $\begin{array}{l}\$ 25,000- \\
\$ 34,999\end{array}$ \\
\hline \multicolumn{9}{|l|}{ More Than High School } \\
\hline \% Below Poverty Line & 3.9 & 11.6 & 16.5 & 22.0 & 20.6 & 17.7 & 12.1 & 12.0 \\
\hline Median Household Income & $\begin{array}{c}\$ 65,000- \\
\$ 74,000\end{array}$ & $\begin{array}{c}\$ 45,000- \\
\$ 54,000\end{array}$ & $\begin{array}{c}\$ 25,000- \\
\$ 34,999\end{array}$ & $\begin{array}{c}\$ 25,000- \\
\$ 34,999\end{array}$ & $\begin{array}{c}\$ 35,000- \\
\$ 44,999\end{array}$ & $\begin{array}{c}\$ 25,000- \\
\$ 34,999\end{array}$ & $\begin{array}{c}\$ 45,000- \\
\$ 54,000\end{array}$ & $\begin{array}{l}\$ 45,000 \\
\$ 54,000\end{array}$ \\
\hline
\end{tabular}




\section{Disability Participation Restriction $\begin{gathered}\text { Activity } \\ \text { Limitation }\end{gathered}$ Impairments}

\section{No At least 1 Work}

\% Employed During... $\quad$ Disability of the 6 Limitation

All

Reference Period

Sometime in Previous Year

Full-Time in Previous Year

\section{Men}

Reference Period

Sometime in Previous Year

Full-Time in Previous Year

Women

Reference Period

Sometime in Previous Year

Full-Time in Previous Year

\section{White}

Reference Period

Sometime in Previous Year

Full-Time in Previous Year

\section{Black}

Reference Period

Sometime in Previous Year

Full-Time in Previous Year

\section{Hispanic}

Reference Period

Sometime in Previous Year

Full-Time in Previous Year

\section{Native American}

Reference Period

Sometime in Previous Year

Full-Time in Previous Year

\section{Asian}

Reference Period

Sometime in Previous Year

Full-Time in Previous Year

\section{LT High School}

Reference Period

Sometime in Previous Year

Full-Time in Previous Year

High School

Reference Period

Sometime in Previous Year

Full-Time in Previous Year

More Than High School

Reference Period

Sometime in Previous Year

83.3

88.3

47.3

57.9

62.8

29.8

90.8

95.1

75.4

75.8

81.4

50.3

83.6

88.3

63.5

49.2

61.9

34.3

45.9

54.8

26.3

83.1

90.4

62.9

78.9

82.0

56.9

73.1

86.5

44.4

49.5

59.7

31.4

29.8

42.0

16.3

IADLs

ADLs

18.3

32.8

32.8

46.6

20.5

18.3

25.7

14.1

19.8

6.2

19.2

25.8

11.0

27.3

19.7

9.3

38.1

27.2

14.3

12.6

8.4

1.7

31.9

20.3

13.8

44.2

28.0

19.3

17.2

4.7

\section{0}

20.3

7.9

17.5

31.6

13.8

22.1

12.7

4.7

21.7

13.1

39.9

17.4

15.8

8.8

32.5

22.5

8.8

22.7

11.0

0.0

0.0

37.2

21.5

3.6

\section{3}

11.3

50.2

34.7

13.3

2.5

0.0

0.0

$81.1 \quad 47.0$

29.4

22.2

0.0

22.2

38.2

$84.9 \quad 58.3$

38.7

22.2

22.8

$72.9 \quad 30.0$

15.4

8.3

25.6

3.4

39.5

12.6

5.6

49.4

16.3

2.5

0.0

\section{9}

46.9

30.7

19.6

43.6

7.2

32.0

88.0
61.5

58.2
28.8

15.5

7.9

19.3

2.9

$\begin{array}{lll}85.6 & 57.3 \quad 38.8\end{array}$

90.4

67.9

51.9

\section{7}

26.4

Mental Physical Sensory

37.1

43.8

58.6

51.8

53.8

66.6

21.3

27.2

43.4

38.1

42.6

64.6

56.8

55.5

73.8

20.6

30.9

48.8

36.5

44.6

49.5

48.7

52.8

55.7

21.8

25.1

35.4

36.5

45.3

60.2

50.8

54.5

69.0

21.5

28.1

46.4

39.6

36.1

38.0

58.1

19.5

50.2

43.6

24.0

26.8

33.8

36.5

68.8

43.9

48.4

70.6

14.6

19.1

46.2

32.4

41.3

30.4

25.0

77.7

37.6

66.1

9.0

5.3

40.5

47.8

42.2

46.6

57.1

70.0

19.3

38.8

42.2

24.2

24.8

37.0

43.0

33.5

42.1

12.7

11.8

27.4

40.0

43.8

57.4

50.4

55.9

66.8

23.2

27.0

43.4 
Table 6. Multiple Disabilities, Respondents Aged 18-64

Percent of respondents with at least one disability in each single or dual disability category

\begin{tabular}{|c|c|c|c|c|c|c|}
\hline & Employment & IADLs & ADLs & Physical & Mental & Sensory \\
\hline Employment & 58.3 & 12.6 & 5.6 & 34.0 & 10.0 & 4.4 \\
\hline IADLs & 12.6 & 13.5 & 4.8 & 9.7 & 3.1 & 1.5 \\
\hline ADLs & 5.6 & 4.8 & 5.9 & 4.5 & 1.3 & 0.7 \\
\hline Physical & 34.0 & 9.7 & 4.5 & 61.7 & 9.7 & 4.4 \\
\hline Mental & 10.0 & 3.1 & 1.3 & 9.7 & 20.3 & 1.5 \\
\hline Sensory & 4.4 & 1.5 & 0.7 & 4.4 & 1.5 & 11.4 \\
\hline Category Disability Only & 17.89 & 0.28 & 0.16 & 23.77 & 7.99 & 5.38 \\
\hline
\end{tabular}

Source: Authors' calculations from 2002 National Health Interview Survey (NHIS).

Note: The first cell in the first column can be interpreted as the percent of disabled respondents with an employment disability.

The second cell in the first column can be interpreted as the percent of disabled respondents with both an employment and IADL disability.

Percent of respondents having a disability conditional on reporting a category disability

\begin{tabular}{|c|c|c|c|c|c|c|}
\hline & Employment & IADLs & ADLs & Physical & Mental & Sensory \\
\hline Employment & 100.0 & 93.4 & 93.8 & 55.2 & 49.3 & 38.4 \\
\hline IADLs & 21.7 & 100.0 & 80.0 & 15.7 & 15.4 & 12.8 \\
\hline ADLs & 9.6 & 35.2 & 100.0 & 7.3 & 6.5 & 5.9 \\
\hline Physical & 58.3 & 71.7 & 75.6 & 100.0 & 47.9 & 38.9 \\
\hline Mental & 17.2 & 23.1 & 22.1 & 15.8 & 100.0 & 12.7 \\
\hline Sensory & 7.5 & 10.8 & 11.3 & 7.2 & 7.1 & 100.0 \\
\hline Category Disability Only & 30.7 & 2.1 & 2.7 & 38.6 & 39.3 & 47.2 \\
\hline
\end{tabular}


Table 7. Multiple Disabilities, Respondents Aged 65+

Percent of respondents with at least one disability in each single or dual disability category

\begin{tabular}{|c|c|c|c|c|c|c|}
\hline & Employment & IADLs & ADLs & Physical & Mental & Sensory \\
\hline Employment & 51.69 & 18.96 & 9.49 & 35.16 & 2.36 & 10.19 \\
\hline IADLs & 18.96 & 25.54 & 10.43 & 19.83 & 1.55 & 6.12 \\
\hline ADLs & 9.49 & 10.43 & 12.76 & 10.39 & 1.10 & 3.27 \\
\hline Physical & 35.16 & 19.83 & 10.39 & 72.95 & 3.13 & 13.54 \\
\hline Mental & 2.36 & 1.55 & 1.10 & 3.13 & 4.41 & 1.03 \\
\hline Sensory & 10.19 & 6.12 & 3.27 & 13.54 & 1.03 & 24.81 \\
\hline Category Disability Only & 10.52 & 1.02 & 0.05 & 26.61 & 0.60 & 7.86 \\
\hline
\end{tabular}

Source: Authors' calculations from 2002 National Health Interview Survey (NHIS).

Note: The first cell in the first column can be interpreted as the percent of disabled respondents with an employment disability.

The second cell in the first column can be interpreted as the percent of disabled respondents with both an employment and IADL disability.

Percent of respondents having a disability conditional on reporting a category disability

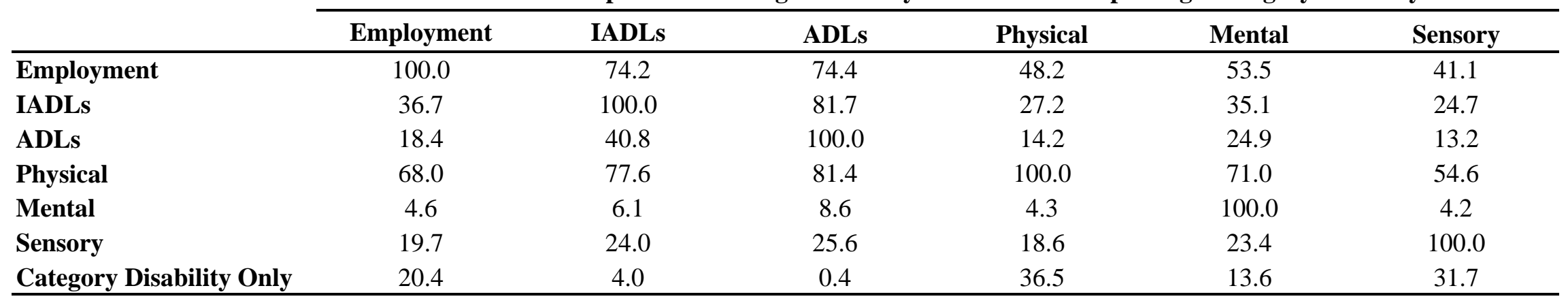




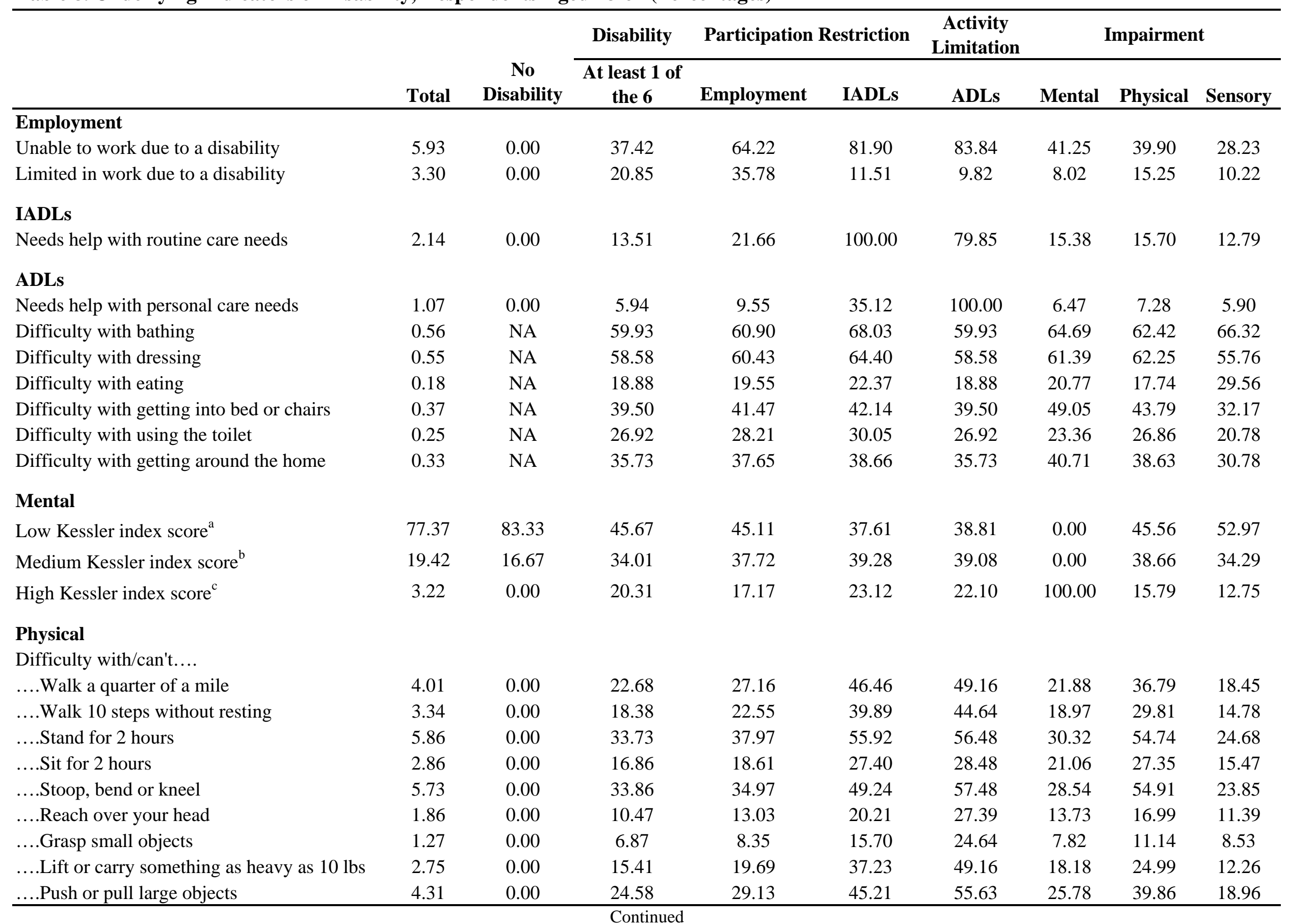




\begin{tabular}{|c|c|c|c|c|c|c|c|c|c|}
\hline & \multirow[b]{2}{*}{ Total } & \multirow{2}{*}{$\begin{array}{c}\text { No } \\
\text { Disability }\end{array}$} & \multirow{2}{*}{$\begin{array}{c}\text { Disability } \\
\text { At least } 1 \text { of } \\
\text { the } 6 \\
\end{array}$} & \multicolumn{2}{|c|}{ Participation Restriction } & \multirow{2}{*}{$\begin{array}{c}\begin{array}{c}\text { Activity } \\
\text { Limitation }\end{array} \\
\text { ADLs }\end{array}$} & \multicolumn{3}{|c|}{ Impairment } \\
\hline & & & & Employment & IADLs & & Mental & Physical & Sensory \\
\hline \multicolumn{10}{|l|}{ Sensory } \\
\hline Blind $^{\mathrm{d}}$ & 2.95 & 0.00 & 6.42 & 6.39 & 10.70 & 9.46 & 3.40 & 4.50 & 41.00 \\
\hline Deaf & 0.19 & 0.00 & 1.12 & 0.89 & 1.47 & 0.42 & 0.52 & 0.58 & 9.81 \\
\hline Difficulty hearing without hearing aid & 1.42 & 0.00 & 8.93 & 5.10 & 6.19 & 8.25 & 5.60 & 5.54 & 78.37 \\
\hline
\end{tabular}

Source: Authors' calculations from 2002 National Health Interview Survey (NHIS).

a) Kessler index score 0-3

b) Kessler index score 4-12

c) Kessler index score 13+

d) Respondents are only asked this question is they first answered that they had vision trouble. The numbers in this column are the responses conditional on the "lead-in" 


\begin{tabular}{|c|c|c|c|c|c|c|c|c|c|}
\hline & \multirow[b]{2}{*}{ Total } & \multirow{2}{*}{$\begin{array}{c}\text { No } \\
\text { Disability }\end{array}$} & \multirow{2}{*}{$\begin{array}{c}\text { Disability } \\
\begin{array}{l}\text { At least } 1 \text { of } \\
\text { the } 6\end{array} \\
\end{array}$} & \multicolumn{2}{|c|}{ Participation Restriction } & \multirow{2}{*}{$\begin{array}{c}\begin{array}{c}\text { Activity } \\
\text { Limitation }\end{array} \\
\text { ADLs } \\
\end{array}$} & \multicolumn{3}{|c|}{ Impairment } \\
\hline & & & & Employment & IADLs & & Mental & Physical & Sensory \\
\hline \multicolumn{10}{|l|}{ Employment } \\
\hline Unable to work due to a disability & 13.79 & 0.00 & 29.05 & 56.20 & 57.04 & 61.73 & 33.76 & 29.34 & 26.55 \\
\hline Limited in work due to a disability & 10.74 & 0.00 & 22.64 & 43.80 & 17.19 & 12.67 & 19.68 & 18.85 & 14.53 \\
\hline \multicolumn{10}{|l|}{ IADLs } \\
\hline Needs help with routine care needs & 12.12 & 0.00 & 25.54 & 36.68 & 100.00 & 81.75 & 35.21 & 27.19 & 24.67 \\
\hline \multicolumn{10}{|l|}{ ADLs } \\
\hline Needs help with personal care needs & 6.06 & 0.00 & 12.76 & 18.37 & 40.85 & 100.00 & 24.84 & 14.24 & 13.16 \\
\hline Difficulty with bathing & 77.79 & NA & 77.79 & 78.13 & 82.56 & 77.79 & 82.84 & 78.15 & 77.86 \\
\hline Difficulty with dressing & 56.74 & NA & 56.74 & 55.51 & 61.95 & 56.74 & 60.91 & 55.64 & 50.57 \\
\hline Difficulty with eating & 26.64 & NA & 26.64 & 28.07 & 30.66 & 26.64 & 16.21 & 24.65 & 21.72 \\
\hline Difficulty with getting into bed or chairs & 47.99 & NA & 47.99 & 45.44 & 49.27 & 47.99 & 54.29 & 47.75 & 44.05 \\
\hline Difficulty with using the toilet & 36.21 & NA & 32.21 & 34.16 & 38.77 & 36.21 & 54.89 & 34.74 & 35.33 \\
\hline Difficulty with getting around the home & 40.99 & NA & 40.99 & 40.02 & 44.66 & 40.99 & 59.57 & 39.22 & 45.93 \\
\hline \multicolumn{10}{|l|}{ Mental } \\
\hline Low Kessler index score $^{a}$ & 80.45 & 91.05 & 68.71 & 64.98 & 59.11 & 50.64 & 0.00 & 65.95 & 68.35 \\
\hline Medium Kessler index score ${ }^{\mathrm{b}}$ & 17.45 & 8.94 & 26.87 & 30.47 & 34.80 & 40.77 & 0.00 & 29.76 & 27.49 \\
\hline High Kessler index score $^{c}$ & 2.10 & 0.00 & 4.41 & 4.57 & 6.09 & 8.60 & 100.00 & 4.28 & 4.17 \\
\hline \multicolumn{10}{|l|}{ Physical } \\
\hline \multicolumn{10}{|l|}{ Difficulty with/can't.... } \\
\hline ....Walk a quarter of a mile & 18.84 & 0.00 & 39.70 & 43.49 & 55.75 & 60.12 & 49.97 & 54.42 & 32.39 \\
\hline ....Walk 10 steps without resting & 13.89 & 0.00 & 29.26 & 33.76 & 49.97 & 57.21 & 44.50 & 40.10 & 23.38 \\
\hline ....Stand for 2 hours & 21.85 & 0.00 & 46.04 & 48.42 & 59.60 & 64.91 & 55.32 & 63.11 & 36.87 \\
\hline ....Sit for 2 hours & 5.13 & 0.00 & 10.81 & 11.57 & 15.41 & 19.73 & 13.25 & 14.81 & 9.32 \\
\hline ....Stoop, bend or kneel & 21.18 & 0.00 & 44.62 & 44.87 & 56.09 & 61.30 & 53.52 & 61.16 & 33.87 \\
\hline ....Reach over your head & 5.84 & 0.00 & 12.31 & 15.11 & 23.33 & 31.75 & 19.82 & 16.87 & 10.82 \\
\hline ....Grasp small objects & 4.83 & 0.00 & 10.17 & 11.09 & 16.08 & 26.36 & 23.21 & 13.94 & 11.18 \\
\hline ....Lift or carry something as heavy as $10 \mathrm{lbs}$ & 10.76 & 0.00 & 22.66 & 27.21 & 44.53 & 56.21 & 39.91 & 31.06 & 17.82 \\
\hline ....Push or pull large objects & 14.49 & 0.00 & 30.53 & 34.04 & 47.63 & 55.28 & 47.02 & 41.85 & 24.16 \\
\hline
\end{tabular}


Table 9 (continued). Underlying Indicators of Disability, Respondents Aged 65+ (Percentages)

\begin{tabular}{|c|c|c|c|c|c|c|c|c|c|}
\hline & \multirow[b]{2}{*}{ Total } & \multirow{2}{*}{$\begin{array}{c}\text { No } \\
\text { Disability } \\
\end{array}$} & \multirow{2}{*}{$\begin{array}{c}\text { Disability } \\
\begin{array}{l}\text { At least } 1 \text { of } \\
\text { the } 6\end{array} \\
\end{array}$} & \multicolumn{2}{|c|}{ Participation Restriction } & \multirow{2}{*}{$\begin{array}{c}\text { Activity } \\
\text { Limitation } \\
\text { ADLs } \\
\end{array}$} & \multicolumn{3}{|c|}{ Impairment } \\
\hline & & & & Employment & IADLs & & Mental & Physical & Sensory \\
\hline \multicolumn{10}{|l|}{ Sensory } \\
\hline Blind $^{\mathrm{d}}$ & 5.62 & 0.00 & 7.59 & 7.98 & 10.86 & 12.56 & 4.50 & 6.10 & 23.97 \\
\hline Deaf & 1.00 & 0.00 & 2.11 & 2.09 & 2.23 & 3.72 & 0.58 & 2.09 & 8.51 \\
\hline Difficulty hearing without hearing aid & 10.03 & 0.00 & 21.13 & 15.96 & 18.55 & 18.20 & 21.44 & 15.40 & 85.20 \\
\hline $\begin{array}{l}\text { Source: Author's calculations from } 2002 \mathrm{~N} \\
\text { a) Kessler index score } 0-3 \\
\text { b) Kessler index score } 4-12 \\
\text { c) Kessler index score } 13+\end{array}$ & alth Inter & lew Survey $(\mathrm{N}$ & HIS) & & & 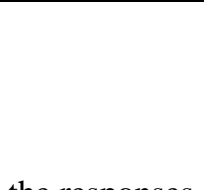 & & & \\
\hline
\end{tabular}




\begin{tabular}{|c|c|c|c|c|c|c|c|c|c|}
\hline & \multirow[b]{2}{*}{ Total } & \multirow{2}{*}{$\begin{array}{c}\text { No } \\
\text { Disability }\end{array}$} & \multirow{2}{*}{$\begin{array}{c}\text { Disability } \\
\text { At least } 1 \\
\text { of the } 6\end{array}$} & \multicolumn{2}{|c|}{ Participation Restriction } & \multirow{2}{*}{$\begin{array}{c}\begin{array}{c}\text { Activity } \\
\text { Limitation }\end{array} \\
\text { ADLs }\end{array}$} & \multirow[b]{2}{*}{ Mental } & \multicolumn{2}{|c|}{ Impairment } \\
\hline & & & & Employment & IADLs & & & Physical & Sensory \\
\hline \multicolumn{10}{|c|}{ Self-reported health status } \\
\hline Excellent/Very Good & 66.86 & 74.24 & 27.68 & 17.82 & 12.34 & 9.89 & 26.53 & 21.78 & 37.40 \\
\hline Good & 23.67 & 21.81 & 33.54 & 31.14 & 24.11 & 20.86 & 26.00 & 31.75 & 31.04 \\
\hline Fair/Poor & 9.39 & 3.89 & 38.58 & 50.79 & 63.18 & 69.24 & 46.98 & 46.26 & 31.13 \\
\hline Don't know/refused & 0.09 & 0.07 & 0.19 & 0.25 & 0.36 & 0.00 & 0.48 & 0.21 & 0.42 \\
\hline \multicolumn{10}{|c|}{ Health status compared to 12 months ago } \\
\hline Better & 18.17 & 17.85 & 19.89 & 20.46 & 18.27 & 17.46 & 14.67 & 17.42 & 20.02 \\
\hline About the Same & 73.77 & 77.64 & 53.19 & 48.76 & 41.80 & 43.15 & 46.33 & 49.48 & 58.94 \\
\hline Worse & 7.74 & 4.21 & 26.51 & 30.30 & 39.22 & 38.72 & 38.48 & 32.78 & 20.57 \\
\hline Don't know/refused & 0.32 & 0.30 & 0.42 & 0.47 & 0.70 & 0.67 & 0.53 & 0.32 & 0.47 \\
\hline \multicolumn{10}{|c|}{$\begin{array}{l}\text { Percentage having difficulty performing an } \\
\text { activity and having a health problem }\end{array}$} \\
\hline Vision or Seeing & 2.91 & 1.20 & 4.56 & 5.98 & 7.73 & 7.14 & 10.45 & 5.04 & 12.51 \\
\hline Hearing & 0.72 & 0.05 & 1.37 & 1.90 & 3.83 & 2.71 & 2.73 & 1.33 & 12.09 \\
\hline Arthritis & 27.07 & 21.04 & 32.89 & 32.54 & 35.97 & 31.47 & 31.29 & 36.53 & 35.63 \\
\hline Back or Neck & 30.17 & 27.02 & 33.21 & 35.20 & 32.76 & 31.68 & 33.95 & 35.33 & 32.90 \\
\hline Fractures, Bone Injury & 14.49 & 14.86 & 14.14 & 14.11 & 10.44 & 10.68 & 12.44 & 15.45 & 11.87 \\
\hline Other Injury & 3.77 & 3.20 & 4.32 & 4.80 & 3.99 & 3.53 & 2.87 & 4.66 & 5.55 \\
\hline Heart & 4.25 & 1.46 & 6.95 & 9.54 & 11.97 & 12.95 & 6.67 & 7.55 & 7.59 \\
\hline Stroke & 1.57 & 0.11 & 2.97 & 4.62 & 8.05 & 9.67 & 3.87 & 3.26 & 4.22 \\
\hline Hypertension & 3.51 & 1.14 & 5.79 & 6.35 & 8.35 & 12.53 & 8.86 & 6.62 & 7.97 \\
\hline Diabetes & 3.38 & 0.80 & 5.86 & 7.38 & 8.97 & 10.55 & 6.88 & 6.70 & 8.37 \\
\hline Lung & 6.94 & 4.15 & 9.64 & 12.17 & 14.53 & 14.69 & 14.95 & 10.58 & 14.25 \\
\hline Cancer & 1.00 & 0.36 & 1.61 & 2.31 & 3.08 & 4.89 & 2.63 & 1.68 & 2.77 \\
\hline Birth Defect & 0.60 & 0.36 & 0.83 & 1.29 & 1.71 & 2.55 & 0.40 & 0.90 & 1.81 \\
\hline MR & 0.58 & 0.10 & 1.03 & 1.60 & 3.30 & 5.89 & 1.62 & 0.63 & 1.43 \\
\hline Other Developmental & 0.32 & 0.07 & 0.57 & 0.67 & 1.81 & 3.33 & 0.69 & 0.55 & 1.07 \\
\hline Senility & 0.12 & 0.01 & 0.23 & 0.28 & 0.24 & 0.00 & 0.20 & 0.17 & 0.72 \\
\hline Depression, Anxiety & 8.28 & 3.49 & 12.90 & 16.12 & 18.30 & 17.74 & 40.53 & 11.56 & 16.43 \\
\hline
\end{tabular}




\begin{tabular}{|c|c|c|c|c|c|c|c|c|c|}
\hline & \multirow[b]{2}{*}{ Total } & \multirow[b]{2}{*}{$\begin{array}{c}\text { No } \\
\text { Disability }\end{array}$} & \multirow{2}{*}{$\begin{array}{c}\text { Disability } \\
\text { At least } 1 \\
\text { of the } 6\end{array}$} & \multicolumn{2}{|c|}{ Participation Restriction } & \multirow{2}{*}{$\begin{array}{c}\begin{array}{c}\text { Activity } \\
\text { Limitation }\end{array} \\
\text { ADLs } \\
\end{array}$} & \multirow[b]{2}{*}{ Mental } & \multicolumn{2}{|c|}{ Impairment } \\
\hline & & & & Employment & IADLs & & & Physical & Sensory \\
\hline \multicolumn{10}{|c|}{$\begin{array}{l}\text { Percentage having difficulty performing an } \\
\text { activity and having a health problem }\end{array}$} \\
\hline Weight & 7.28 & 8.46 & 6.14 & 5.68 & 9.03 & 10.60 & 8.91 & 6.35 & 7.15 \\
\hline Missing Limb & 0.23 & 0.03 & 0.42 & 0.70 & 0.61 & 0.88 & 0.00 & 0.45 & 0.97 \\
\hline Other Musculoskeletal & 12.80 & 13.69 & 11.94 & 11.32 & 14.88 & 11.91 & 10.42 & 12.60 & 12.24 \\
\hline Other Circulatory & 2.21 & 1.60 & 2.80 & 3.24 & 3.71 & 5.08 & 2.89 & 3.14 & 3.31 \\
\hline Other Endocrine & 0.57 & 0.33 & 0.79 & 1.13 & 1.65 & 2.09 & 2.31 & 0.87 & 0.73 \\
\hline Other Nervous & 5.41 & 3.11 & 7.63 & 9.71 & 17.44 & 22.32 & 7.61 & 8.38 & 8.55 \\
\hline Digestive & 1.05 & 0.38 & 1.70 & 1.76 & 2.38 & 2.12 & 2.27 & 1.77 & 2.19 \\
\hline Genitourinary & 1.15 & 0.53 & 1.74 & 2.25 & 3.84 & 2.69 & 1.41 & 1.93 & 4.04 \\
\hline Skin & 0.10 & 0.10 & 0.11 & 0.19 & 0.15 & 0.00 & 0.13 & 0.14 & 0.26 \\
\hline Blood & 0.11 & 0.03 & 0.19 & 0.20 & 0.36 & 0.82 & 0.38 & 0.19 & 0.00 \\
\hline Tumors, Cysts & 0.21 & 0.09 & 0.33 & 0.34 & 0.83 & 0.54 & 0.50 & 0.37 & 0.84 \\
\hline Alcohol and Drugs & 0.03 & 0.00 & 0.06 & 0.10 & 0.25 & 0.58 & 0.28 & 0.04 & 0.00 \\
\hline Other Mental & 0.30 & 0.30 & 0.29 & 0.46 & 0.92 & 0.41 & 0.47 & 0.16 & 0.00 \\
\hline Effects from Surgery & 0.51 & 0.22 & 0.78 & 0.60 & 1.50 & 0.72 & 0.39 & 0.80 & 0.87 \\
\hline Old Age & 0.58 & 1.00 & 0.18 & 0.08 & 0.12 & 0.28 & 0.00 & 0.11 & 0.63 \\
\hline Fatigue & 0.79 & 1.13 & 0.46 & 0.57 & 0.66 & 0.17 & 1.16 & 0.49 & 0.78 \\
\hline Pregnancy-Related & 1.01 & 1.24 & 0.79 & 0.16 & 0.42 & 0.00 & 1.50 & 0.77 & 0.00 \\
\hline \multicolumn{10}{|l|}{ BMI } \\
\hline Underweight & 1.15 & 1.11 & 1.35 & 1.74 & 3.21 & 5.16 & 2.41 & 1.41 & 1.17 \\
\hline Normal & 38.43 & 40.27 & 28.66 & 29.19 & 27.88 & 27.01 & 33.97 & 24.34 & 26.84 \\
\hline Overweight & 32.89 & 33.50 & 29.65 & 28.19 & 23.22 & 21.71 & 29.90 & 28.43 & 32.91 \\
\hline Mild Obesity & 14.51 & 13.67 & 19.02 & 19.14 & 17.17 & 16.80 & 15.19 & 19.84 & 20.60 \\
\hline Moderate Obesity & 5.06 & 4.33 & 8.98 & 9.71 & 11.49 & 10.30 & 7.83 & 10.59 & 10.45 \\
\hline Severe Obesity & 3.02 & 2.24 & 7.14 & 7.33 & 10.89 & 11.60 & 6.07 & 9.84 & 5.59 \\
\hline Missing & 4.93 & 4.88 & 5.20 & 4.70 & 6.15 & 7.41 & 4.63 & 5.48 & 2.44 \\
\hline
\end{tabular}

a) Only those who answered that they had some difficulty performing a particular task were asked about the underlying condition causing that difficulty.

The "non-disabled" respondents who were asked this question are the small number of respondents who had a low level of difficulty with a certain task. 


\begin{tabular}{|c|c|c|c|c|c|c|c|c|c|}
\hline & \multirow[b]{2}{*}{ Total } & \multirow{2}{*}{$\begin{array}{c}\text { No } \\
\text { Disability }\end{array}$} & \multirow{2}{*}{$\begin{array}{c}\text { Disability } \\
\text { At least } 1 \\
\text { of the } 6\end{array}$} & \multicolumn{2}{|c|}{ Participation Restriction } & \multirow{2}{*}{$\begin{array}{c}\begin{array}{c}\text { Activity } \\
\text { Limitation }\end{array} \\
\text { ADLs }\end{array}$} & \multicolumn{3}{|c|}{ Impairment } \\
\hline & & & & Employment & IADLs & & Mental & Physical & Sensory \\
\hline \multicolumn{10}{|c|}{ Self-reported health status } \\
\hline Excellent/Very Good & 38.09 & 53.13 & 21.45 & 16.33 & 10.26 & 8.22 & 19.42 & 17.85 & 23.93 \\
\hline Good & 34.99 & 35.63 & 34.27 & 30.63 & 26.99 & 22.29 & 20.92 & 33.50 & 33.26 \\
\hline Fair/Poor & 26.72 & 11.11 & 44.00 & 52.63 & 62.12 & 69.30 & 59.66 & 48.37 & 42.71 \\
\hline Don't know/refused & 0.21 & 0.14 & 0.28 & 0.41 & 0.63 & 0.18 & 0.00 & 0.28 & 0.10 \\
\hline \multicolumn{10}{|c|}{ Health status compared to 12 months ago } \\
\hline Better & 13.24 & 12.19 & 14.39 & 15.07 & 13.02 & 13.90 & 14.59 & 14.57 & 11.15 \\
\hline About the Same & 72.28 & 81.89 & 61.64 & 57.11 & 49.78 & 42.71 & 39.00 & 58.51 & 62.62 \\
\hline Worse & 14.05 & 5.54 & 23.47 & 27.18 & 36.50 & 42.68 & 46.41 & 26.34 & 25.74 \\
\hline Don't know/refused & 0.44 & 0.38 & 0.50 & 0.65 & 0.70 & 0.71 & 0.00 & 0.58 & 0.49 \\
\hline \multicolumn{10}{|c|}{$\begin{array}{l}\text { Percentage having difficulty performing an } \\
\text { activity and having a health problem }\end{array}$} \\
\hline Vision or Seeing & 8.00 & 2.29 & 10.60 & 13.10 & 20.72 & 20.01 & 24.66 & 11.05 & 18.43 \\
\hline Hearing & 3.31 & 0.91 & 4.40 & 5.00 & 6.35 & 4.53 & 12.70 & 3.90 & 15.20 \\
\hline Arthritis & 44.32 & 41.27 & 45.71 & 46.72 & 42.39 & 35.25 & 56.74 & 47.77 & 43.03 \\
\hline Back or Neck & 18.22 & 15.03 & 19.67 & 19.49 & 17.54 & 12.59 & 22.03 & 20.00 & 18.98 \\
\hline Fractures, Bone Injury & 10.55 & 8.18 & 11.63 & 11.29 & 13.27 & 14.46 & 11.47 & 12.60 & 11.87 \\
\hline Other Injury & 2.28 & 2.37 & 2.24 & 3.27 & 2.22 & 3.20 & 3.81 & 2.26 & 2.10 \\
\hline Heart & 11.89 & 5.09 & 14.99 & 16.63 & 18.68 & 23.25 & 17.08 & 16.26 & 16.00 \\
\hline Stroke & 4.52 & 1.03 & 6.11 & 8.07 & 15.32 & 18.40 & 8.74 & 6.44 & 7.14 \\
\hline Hypertension & 5.88 & 2.63 & 7.37 & 8.08 & 9.85 & 12.04 & 11.38 & 8.06 & 7.01 \\
\hline Diabetes & 5.25 & 2.21 & 6.63 & 8.53 & 9.24 & 10.52 & 14.92 & 7.40 & 6.82 \\
\hline Lung & 7.98 & 5.09 & 9.30 & 12.45 & 8.76 & 6.66 & 9.76 & 9.29 & 11.15 \\
\hline Cancer & 2.50 & 0.74 & 3.30 & 4.24 & 5.57 & 7.33 & 8.32 & 3.78 & 3.67 \\
\hline Birth Defect & 0.00 & 0.00 & 0.00 & 0.00 & 0.00 & 0.00 & 0.00 & 0.00 & 0.00 \\
\hline MR & 0.04 & 0.00 & 0.06 & 0.12 & 0.00 & 0.00 & 0.00 & 0.08 & 0.00 \\
\hline Other Developmental & 0.02 & 0.00 & 0.03 & 0.00 & 0.00 & 0.00 & 0.00 & 0.03 & 0.00 \\
\hline Senility & 1.99 & 0.90 & 2.49 & 3.17 & 5.76 & 9.50 & 8.30 & 2.29 & 4.07 \\
\hline Depression, Anxiety & 2.45 & 0.95 & 3.14 & 3.42 & 4.87 & 5.09 & 23.10 & 3.17 & 3.14 \\
\hline
\end{tabular}




\begin{tabular}{|c|c|c|c|c|c|c|c|c|c|}
\hline & \multirow[b]{2}{*}{ Total } & \multirow[b]{2}{*}{$\begin{array}{c}\text { No } \\
\text { Disability }\end{array}$} & \multirow{2}{*}{$\begin{array}{c}\text { Disability } \\
\text { At least } 1 \\
\text { of the } 6\end{array}$} & \multicolumn{2}{|c|}{ Participation Restriction } & \multirow{2}{*}{$\begin{array}{c}\begin{array}{c}\text { Activity } \\
\text { Limitation }\end{array} \\
\text { ADLs }\end{array}$} & \multicolumn{3}{|c|}{ Impairment } \\
\hline & & & & Employment & IADLs & & Mental & Physical & Sensory \\
\hline \multicolumn{10}{|c|}{$\begin{array}{l}\text { Percentage having difficulty performing an } \\
\text { activity and having a health problem }\end{array}$} \\
\hline Weight & 3.35 & 3.27 & 3.38 & 3.05 & 2.27 & 2.60 & 6.15 & 3.85 & 3.95 \\
\hline Missing Limb & 0.53 & 0.00 & 0.77 & 1.21 & 1.30 & 1.65 & 0.42 & 0.69 & 0.52 \\
\hline Other Musculoskeletal & 9.40 & 9.18 & 9.50 & 9.61 & 8.46 & 5.06 & 4.28 & 9.99 & 8.47 \\
\hline Other Circulatory & 4.03 & 3.82 & 4.13 & 4.87 & 4.74 & 5.78 & 1.93 & 4.57 & 5.13 \\
\hline Other Endocrine & 0.47 & 0.12 & 0.63 & 0.94 & 1.17 & 1.46 & 0.95 & 0.67 & 0.67 \\
\hline Other Nervous & 3.36 & 2.10 & 3.94 & 5.48 & 5.82 & 8.22 & 5.39 & 3.99 & 3.55 \\
\hline Digestive & 0.70 & 0.68 & 0.71 & 0.87 & 0.86 & 0.93 & 0.00 & 0.86 & 0.96 \\
\hline Genitourinary & 1.14 & 0.42 & 1.48 & 2.27 & 3.22 & 4.94 & 2.49 & 1.61 & 1.28 \\
\hline Skin & 0.08 & 0.00 & 0.12 & 0.05 & 0.10 & 0.00 & 0.66 & 0.14 & 0.13 \\
\hline Blood & 0.10 & 0.16 & 0.07 & 0.00 & 0.00 & 0.00 & 0.00 & 0.09 & 0.00 \\
\hline Tumors, Cysts & 0.05 & 0.00 & 0.07 & 0.13 & 0.03 & 0.07 & 0.00 & 0.08 & 0.00 \\
\hline Alcohol and Drugs & 0.00 & 0.00 & 0.00 & 0.00 & 0.00 & 0.00 & 0.00 & 0.00 & 0.00 \\
\hline Other Mental & 0.00 & 0.00 & 0.00 & 0.00 & 0.00 & 0.00 & 0.00 & 0.00 & 0.00 \\
\hline Effects from Surgery & 0.34 & 0.00 & 0.50 & 0.64 & 0.84 & 1.44 & 0.84 & 0.46 & 0.28 \\
\hline Old Age & 4.19 & 6.47 & 3.14 & 3.40 & 5.02 & 5.09 & 1.32 & 2.87 & 4.02 \\
\hline Fatigue & 0.79 & 0.69 & 0.83 & 0.80 & 0.90 & 1.37 & 0.00 & 0.71 & 1.22 \\
\hline Pregnancy-Related & 0.00 & 0.00 & 0.00 & 0.00 & 0.00 & 0.00 & 0.00 & 0.00 & 0.00 \\
\hline \multicolumn{10}{|l|}{ BMI } \\
\hline Underweight & 1.71 & 1.24 & 2.23 & 2.52 & 4.05 & 4.60 & 3.96 & 2.74 & 2.83 \\
\hline Normal & 37.13 & 39.16 & 34.88 & 34.71 & 39.02 & 43.20 & 36.54 & 33.28 & 34.54 \\
\hline Overweight & 35.81 & 38.71 & 32.59 & 31.30 & 24.37 & 24.59 & 31.08 & 30.03 & 38.43 \\
\hline Mild Obesity & 14.70 & 13.89 & 15.60 & 16.24 & 13.44 & 11.95 & 18.43 & 16.87 & 14.71 \\
\hline Moderate Obesity & 4.41 & 2.45 & 6.58 & 6.53 & 6.07 & 5.77 & 3.41 & 7.79 & 4.37 \\
\hline Severe Obesity & 2.00 & 0.68 & 3.46 & 3.35 & 4.72 & 2.80 & 4.24 & 4.44 & 1.19 \\
\hline Missing & 4.24 & 3.87 & 4.65 & 5.34 & 8.33 & 7.08 & 2.35 & 4.84 & 3.93 \\
\hline
\end{tabular}

a) Only those who answered that they had some difficulty performing a particular task were asked about the underlying condition causing that difficulty.

The "non-disabled" respondents who were asked this question are the small number of respondents who had a low level of difficulty with a certain task. 


\begin{tabular}{|c|c|c|c|c|c|c|c|c|c|}
\hline & \multirow[b]{2}{*}{ Total } & \multirow{2}{*}{$\begin{array}{c}\text { No } \\
\text { Disability }\end{array}$} & \multirow{2}{*}{$\begin{array}{c}\text { Disability } \\
\text { At least } 1 \\
\text { of the } 6\end{array}$} & \multicolumn{2}{|c|}{ Participation Restriction } & \multirow{2}{*}{$\begin{array}{c}\begin{array}{c}\text { Activity } \\
\text { Limitation }\end{array} \\
\text { ADLs }\end{array}$} & \multicolumn{3}{|c|}{ Impairment } \\
\hline & & & & Employment & IADLs & & Mental & Physical & Sensory \\
\hline \multicolumn{10}{|l|}{ Usual place to go when sick } \\
\hline Clinic or health center & 16.44 & 15.88 & 19.24 & 20.66 & 18.50 & 15.47 & 23.07 & 18.54 & 15.88 \\
\hline $\mathrm{HMO}$ & 78.97 & 79.77 & 75.01 & 73.01 & 76.34 & 80.01 & 68.67 & 76.52 & 78.35 \\
\hline Hospital emergency room & 1.19 & 1.14 & 1.40 & 1.12 & 0.50 & 0.52 & 3.05 & 1.24 & 1.39 \\
\hline Hospital outpatient department & 1.56 & 1.36 & 2.57 & 3.33 & 3.40 & 3.48 & 3.08 & 2.30 & 2.95 \\
\hline Other & 0.80 & 0.67 & 1.42 & 1.54 & 1.11 & 0.52 & 1.69 & 1.10 & 1.43 \\
\hline Doesn't go to one place & 0.94 & 1.07 & 0.32 & 0.28 & 0.08 & 0.00 & 0.44 & 0.29 & 0.00 \\
\hline Don't know/refused & 0.10 & 0.11 & 0.03 & 0.05 & 0.07 & 0.00 & 0.00 & 0.02 & 0.00 \\
\hline \multicolumn{10}{|c|}{ Place to go for routine or preventive care, if different from usual } \\
\hline Doesn't receive preventive care anywhere & 54.06 & 54.66 & 49.76 & 48.98 & 51.14 & 50.95 & 52.85 & 43.62 & 52.26 \\
\hline Clinic or health center & 9.57 & 9.50 & 10.07 & 9.34 & 12.11 & 11.51 & 11.78 & 12.26 & 7.32 \\
\hline HMO & 19.92 & 19.68 & 21.65 & 22.40 & 19.76 & 16.80 & 18.84 & 24.02 & 21.56 \\
\hline Hospital emergency room & 2.41 & 2.36 & 2.81 & 3.24 & 1.76 & 3.11 & 2.95 & 3.03 & 4.12 \\
\hline Hospital outpatient department & 1.03 & 1.01 & 1.20 & 1.40 & 1.99 & 11.51 & 0.90 & 1.57 & 1.58 \\
\hline Other & 1.62 & 1.45 & 2.84 & 3.95 & 1.39 & 4.13 & 2.57 & 3.32 & 2.56 \\
\hline Doesn't go to one place most often & 7.83 & 7.89 & 7.39 & 5.78 & 6.10 & 0.00 & 7.15 & 8.04 & 4.75 \\
\hline Don't know/refused & 3.55 & 3.45 & 4.28 & 4.90 & 5.75 & 1.99 & 2.96 & 4.12 & 5.84 \\
\hline \multicolumn{10}{|l|}{ Seen/talked to .... in the past 12 months } \\
\hline ....Mental Health Professional & 6.81 & 4.56 & 18.79 & 24.10 & 31.82 & 29.48 & 36.10 & 17.12 & 14.41 \\
\hline ....Eye Doctor & 32.60 & 31.26 & 39.74 & 41.61 & 45.54 & 39.72 & 33.25 & 42.62 & 44.10 \\
\hline ....Foot Doctor & 4.76 & 3.66 & 10.55 & 10.64 & 14.11 & 18.14 & 9.34 & 12.57 & 11.99 \\
\hline ....Chiropractor & 8.47 & 7.73 & 12.41 & 11.85 & 9.53 & 7.31 & 11.34 & 14.02 & 10.12 \\
\hline ....Therapist (PT/OT) & 6.90 & 4.50 & 19.65 & 22.25 & 29.51 & 38.31 & 17.32 & 25.30 & 19.01 \\
\hline ....Nurse Practitioner & 13.44 & 12.08 & 20.64 & 22.79 & 26.99 & 21.83 & 19.97 & 22.52 & 19.21 \\
\hline$\ldots . \mathrm{OB} / \mathrm{GYN}$ & 50.50 & 52.43 & 41.49 & 38.79 & 36.31 & 30.64 & 42.81 & 40.79 & 43.59 \\
\hline ....Medical Specialist & 22.77 & 18.40 & 46.01 & 54.53 & 63.89 & 66.43 & 40.54 & 52.78 & 40.91 \\
\hline ....General Doctor & 64.10 & 61.50 & 77.89 & 81.01 & 85.47 & 89.23 & 71.31 & 82.27 & 74.40 \\
\hline
\end{tabular}




\begin{tabular}{|c|c|c|c|c|c|c|c|c|c|}
\hline & \multirow[b]{2}{*}{ Total } & \multirow{2}{*}{$\begin{array}{c}\text { No } \\
\text { Disability } \\
\end{array}$} & \multirow{2}{*}{$\begin{array}{c}\text { Disability } \\
\text { At least } 1 \\
\text { of the } 6\end{array}$} & \multicolumn{2}{|c|}{ Participation Restriction } & \multirow{2}{*}{$\begin{array}{c}\text { Activity } \\
\text { Limitation } \\
\text { ADLs } \\
\end{array}$} & \multicolumn{3}{|c|}{ Impairment } \\
\hline & & & & Employment & IADLs & & Mental & Physical & Sensory \\
\hline \multicolumn{10}{|c|}{ Number of times in ER in past 12 months } \\
\hline 0 & 79.4 & 82.59 & 62.44 & 58.05 & 52.03 & 48.11 & 51.02 & 60.65 & 66.13 \\
\hline At least 1 time & 19.66 & 16.46 & 36.58 & 40.79 & 47.07 & 50.87 & 48.33 & 38.71 & 33.08 \\
\hline 1 & 12.89 & 11.75 & 18.93 & 19.28 & 15.80 & 15.29 & 20.06 & 18.81 & 18.74 \\
\hline $2-3$ & 4.9 & 3.74 & 11.02 & 12.57 & 18.15 & 19.99 & 16.45 & 11.91 & 8.02 \\
\hline $4-9$ & 1.63 & 0.88 & 5.57 & 7.37 & 10.22 & 12.57 & 9.36 & 6.61 & 5.43 \\
\hline $10+$ & 0.24 & 0.09 & 1.06 & 1.57 & 2.90 & 3.02 & 2.46 & 1.38 & 0.89 \\
\hline Don't know/refused & 0.95 & 0.94 & 0.97 & 1.16 & 0.89 & 1.03 & 0.65 & 0.65 & 0.78 \\
\hline Received at home care in past year? & 0.94 & 0.36 & 3.99 & 5.68 & 14.40 & 26.54 & 4.10 & 5.09 & 3.73 \\
\hline \multicolumn{10}{|c|}{ Number of months received at home care } \\
\hline $1-3$ months & 71.25 & 95.35 & 59.53 & 54.88 & 43.24 & 33.72 & 51.61 & 60.81 & 55.04 \\
\hline 4-6 months & 6.88 & 0.00 & 10.22 & 10.50 & 10.48 & 12.47 & 12.43 & 8.36 & 6.83 \\
\hline 7-9 months & 0.54 & 1.65 & 0.00 & 0.00 & 0.00 & 0.00 & 0.00 & 0.00 & 0.00 \\
\hline 10-12 months & 21.12 & 3.00 & 29.93 & 34.25 & 45.63 & 53.00 & 35.95 & 30.43 & 38.13 \\
\hline Don't know/refused & 0.21 & 0.00 & 0.32 & 0.38 & 0.65 & 0.80 & 0.00 & 0.40 & 0.00 \\
\hline \multicolumn{10}{|c|}{ Total number of home visits in past 12 months } \\
\hline 1 & 20.12 & 47.19 & 6.96 & 3.74 & 3.24 & 0.84 & 12.01 & 6.30 & 3.37 \\
\hline $2-3$ & 15.03 & 25.36 & 10.01 & 7.36 & 2.72 & 1.77 & 10.40 & 9.36 & 16.34 \\
\hline $4-9$ & 22.41 & 10.43 & 28.23 & 31.28 & 22.44 & 17.94 & 14.98 & 27.52 & 21.64 \\
\hline $10+$ & 42.24 & 17.02 & 54.49 & 57.24 & 70.95 & 78.65 & 62.62 & 56.42 & 0.00 \\
\hline Don't know/refused & 0.21 & 0.00 & 0.32 & 0.38 & 0.65 & 0.80 & 0.00 & 0.40 & 58.65 \\
\hline \multicolumn{10}{|c|}{ Number of office visits in the past 12 months } \\
\hline 0 & 20.60 & 22.58 & 10.05 & 7.14 & 4.13 & 2.29 & 15.34 & 6.12 & 14.20 \\
\hline At least 1 time & 77.56 & 75.6 & 87.83 & 90.52 & 94.16 & 96.24 & 82.21 & 92.08 & 84.16 \\
\hline 1 & 17.68 & 19.76 & 6.59 & 5.06 & 3.34 & 1.83 & 5.55 & 4.75 & 10.22 \\
\hline $2-3$ & 25.61 & 27.33 & 16.44 & 13.75 & 10.80 & 15.99 & 15.46 & 14.33 & 15.06 \\
\hline $4-9$ & 21.53 & 19.88 & 30.27 & 29.86 & 26.82 & 22.76 & 20.62 & 31.74 & 29.23 \\
\hline $10+$ & 12.74 & 8.63 & 34.53 & 41.85 & 53.20 & 55.66 & 40.58 & 41.26 & 29.65 \\
\hline Don't know/refused & 1.86 & 1.81 & 2.12 & 2.34 & 1.72 & 1.47 & 2.46 & 1.80 & 1.64 \\
\hline
\end{tabular}




\begin{tabular}{|c|c|c|c|c|c|c|c|c|c|}
\hline & \multirow[b]{2}{*}{ Total } & \multirow{2}{*}{$\begin{array}{c}\text { No } \\
\text { Disability }\end{array}$} & \multirow{2}{*}{$\begin{array}{c}\text { Disability } \\
\text { At least } 1 \\
\text { of the } 6\end{array}$} & \multicolumn{2}{|c|}{ Participation Restriction } & \multirow{2}{*}{$\begin{array}{c}\begin{array}{c}\text { Activity } \\
\text { Limitation }\end{array} \\
\text { ADLs } \\
\end{array}$} & \multicolumn{3}{|c|}{ Impairment } \\
\hline & & & & Employment & IADLs & & Mental & Physical & Sensory \\
\hline $\begin{array}{l}\text { Health care delayed due to cost in the past } \\
12 \text { months }\end{array}$ & 9.20 & 6.86 & 21.62 & 24.52 & 26.20 & 23.77 & 31.20 & 22.09 & 20.00 \\
\hline $\begin{array}{l}\text { Needed, didn't receive health care due to } \\
\text { cost (past year) }\end{array}$ & 6.74 & 4.73 & 17.41 & 19.90 & 22.33 & 17.72 & 25.16 & 17.91 & 15.62 \\
\hline $\begin{array}{l}\text { Can't afford mental care/counseling in past } \\
12 \text { months }\end{array}$ & 2.34 & 1.26 & 8.12 & 8.35 & 10.34 & 7.91 & 20.38 & 7.38 & 6.57 \\
\hline $\begin{array}{l}\text { Was in hospital overnight in the past } 12 \\
\text { months }\end{array}$ & 8.22 & 6.02 & 19.94 & 24.98 & 33.37 & 40.44 & 22.57 & 22.96 & 14.84 \\
\hline \multicolumn{10}{|l|}{ Number of nights in hospital } \\
\hline 1 & 24.09 & 27.42 & 18.73 & 17.06 & 10.61 & 7.34 & 13.64 & 18.15 & 12.18 \\
\hline $2-9$ & 62.32 & 66.98 & 54.84 & 51.60 & 44.29 & 46.32 & 62.09 & 53.69 & 69.47 \\
\hline $10-59$ & 12.01 & 4.88 & 23.42 & 27.26 & 39.09 & 40.40 & 20.89 & 24.93 & 14.74 \\
\hline $60+$ & 0.88 & 0.27 & 1.86 & 2.52 & 2.73 & 3.30 & 1.36 & 1.90 & 0.80 \\
\hline Don't know/refused & 0.71 & 0.45 & 1.14 & 1.56 & 3.27 & 2.64 & 2.02 & 1.32 & 2.81 \\
\hline $\begin{array}{l}\text { Received care } 10+\text { times in the past } 12 \\
\text { months }\end{array}$ & 10.99 & 6.57 & 34.47 & 42.63 & 61.27 & 63.39 & 37.39 & 40.06 & 27.72 \\
\hline
\end{tabular}




\begin{tabular}{|c|c|c|c|c|c|c|c|c|c|}
\hline & \multirow[b]{2}{*}{ Total } & \multirow{2}{*}{$\begin{array}{c}\text { No } \\
\text { Disability }\end{array}$} & \multirow{2}{*}{$\begin{array}{c}\text { Disability } \\
\text { At least } 1 \\
\text { of the } 6\end{array}$} & \multicolumn{2}{|c|}{ Participation Restriction } & \multirow{2}{*}{$\begin{array}{c}\begin{array}{c}\text { Activity } \\
\text { Limitation }\end{array} \\
\text { ADLs }\end{array}$} & \multicolumn{3}{|c|}{ Impairment } \\
\hline & & & & Employment & IADLs & & Mental & Physical & Sensory \\
\hline \multicolumn{10}{|l|}{ Usual place to go when sick } \\
\hline Clinic or health center & 11.39 & 11.59 & 11.17 & 11.48 & 10.49 & 7.96 & 14.29 & 10.03 & 12.15 \\
\hline HMO & 85.49 & 85.89 & 85.05 & 83.79 & 85.54 & 87.70 & 83.53 & 86.23 & 84.29 \\
\hline Hospital emergency room & 0.36 & 0.14 & 0.58 & 0.79 & 0.83 & 0.17 & 0.00 & 0.63 & 0.72 \\
\hline Hospital outpatient department & 2.10 & 1.76 & 2.46 & 3.41 & 2.72 & 3.51 & 0.97 & 2.52 & 1.65 \\
\hline Other & 0.30 & 0.14 & 0.48 & 0.26 & 0.24 & 0.29 & 1.21 & 0.47 & 0.83 \\
\hline Doesn't go to one place & 0.31 & 0.46 & 0.14 & 0.17 & 0.00 & 0.00 & 0.00 & 0.09 & 0.14 \\
\hline Don't know/refused & 0.06 & 0.00 & 0.12 & 0.09 & 0.18 & 0.36 & 0.00 & 0.03 & 0.22 \\
\hline \multicolumn{10}{|c|}{ Place to go for routine or preventive care, if different from usual } \\
\hline Doesn't receive preventive care anywhere & 32.09 & 38.00 & 23.08 & 19.04 & 25.20 & 28.38 & 22.13 & 20.62 & 33.20 \\
\hline Clinic or health center & 11.28 & 10.26 & 12.83 & 13.38 & 11.72 & 12.78 & 13.92 & 13.84 & 13.08 \\
\hline HMO & 34.35 & 32.54 & 37.13 & 38.53 & 31.90 & 31.25 & 53.49 & 42.69 & 20.89 \\
\hline Hospital emergency room & 1.93 & 2.23 & 1.48 & 0.00 & 0.00 & 0.00 & 0.00 & 2.29 & 0.00 \\
\hline Hospital outpatient department & 2.40 & 2.07 & 2.92 & 2.91 & 2.14 & 1.73 & 0.00 & 1.81 & 7.10 \\
\hline Other & 2.68 & 1.37 & 4.67 & 5.36 & 4.75 & 12.03 & 0.00 & 4.40 & 3.91 \\
\hline Doesn't go to one place most often & 5.07 & 5.02 & 5.15 & 4.70 & 4.40 & 2.11 & 0.00 & 3.22 & 6.11 \\
\hline Don't know/refused & 10.19 & 8.52 & 12.74 & 16.06 & 19.90 & 11.71 & 10.45 & 11.13 & 15.71 \\
\hline \multicolumn{10}{|l|}{ Seen/talked to .... in the past 12 months } \\
\hline ....Mental Health Professional & 2.66 & 1.15 & 4.34 & 5.11 & 7.74 & 8.96 & 19.00 & 4.40 & 5.15 \\
\hline ....Eye Doctor & 55.64 & 52.88 & 58.69 & 56.95 & 56.58 & 54.24 & 53.17 & 59.60 & 59.11 \\
\hline ....Foot Doctor & 14.73 & 9.11 & 20.95 & 20.45 & 24.80 & 25.14 & 24.01 & 22.71 & 20.94 \\
\hline ....Chiropractor & 7.14 & 6.65 & 7.68 & 7.46 & 6.22 & 5.51 & 6.18 & 8.47 & 6.22 \\
\hline ....Therapist (PT/OT) & 12.38 & 6.63 & 18.74 & 19.41 & 25.87 & 31.29 & 26.50 & 20.50 & 19.64 \\
\hline .....Nurse Practitioner & 11.54 & 8.79 & 14.58 & 15.76 & 20.64 & 20.26 & 10.87 & 15.44 & 14.94 \\
\hline$\ldots . \mathrm{OB} / \mathrm{GYN}$ & 19.28 & 23.53 & 15.08 & 14.76 & 12.37 & 11.51 & 15.17 & 14.57 & 11.28 \\
\hline ....Medical Specialist & 43.21 & 34.89 & 52.43 & 54.40 & 55.56 & 57.94 & 50.64 & 55.01 & 52.49 \\
\hline ....General Doctor & 83.64 & 79.26 & 88.49 & 89.36 & 90.51 & 89.78 & 87.55 & 90.13 & 87.01 \\
\hline
\end{tabular}




\begin{tabular}{|c|c|c|c|c|c|c|c|c|c|}
\hline & \multirow[b]{2}{*}{ Total } & \multirow[b]{2}{*}{$\begin{array}{c}\text { No } \\
\text { Disability }\end{array}$} & \multirow{2}{*}{$\begin{array}{c}\text { Disability } \\
\text { At least } 1 \\
\text { of the } 6\end{array}$} & \multicolumn{2}{|c|}{ Participation Restriction } & \multirow{2}{*}{$\begin{array}{c}\begin{array}{c}\text { Activity } \\
\text { Limitation }\end{array} \\
\text { ADLs }\end{array}$} & \multicolumn{3}{|c|}{ Impairment } \\
\hline & & & & Employment & IADLs & & Mental & Physical & Sensory \\
\hline \multicolumn{10}{|c|}{ Number of times in ER in past 12 months } \\
\hline 0 & 75.14 & 82.92 & 66.52 & 64.07 & 56.12 & 47.34 & 57.42 & 64.75 & 66.82 \\
\hline At least 1 time & 23.65 & 15.9 & 32.22 & 34.36 & 42.19 & 50.35 & 39.31 & 34.01 & 32.05 \\
\hline 1 & 15.41 & 11.51 & 19.72 & 20.57 & 21.65 & 24.95 & 21.34 & 20.01 & 19.43 \\
\hline $2-3$ & 6.23 & 3.63 & 9.12 & 9.49 & 13.61 & 17.00 & 13.74 & 9.99 & 9.39 \\
\hline $4-9$ & 1.64 & 0.61 & 2.77 & 3.40 & 5.45 & 6.60 & 3.48 & 3.32 & 2.81 \\
\hline $10+$ & 0.37 & 0.15 & 0.61 & 0.90 & 1.48 & 1.80 & 0.75 & 0.69 & 0.42 \\
\hline Don't know/refused & 1.22 & 1.19 & 1.25 & 1.57 & 1.69 & 2.32 & 3.28 & 1.23 & 1.14 \\
\hline Receive at home care in past year? & 6.52 & 1.06 & 12.58 & 15.63 & 31.39 & 46.07 & 20.19 & 13.98 & 13.29 \\
\hline \multicolumn{10}{|c|}{ Number of months received at home care } \\
\hline $1-3$ months & 61.32 & 88.24 & 58.81 & 52.47 & 49.20 & 47.90 & 78.63 & 58.77 & 46.69 \\
\hline 4-6 months & 9.80 & 9.59 & 9.82 & 11.91 & 10.31 & 10.92 & 2.60 & 10.02 & 12.94 \\
\hline 7-9 months & 2.79 & 0.00 & 3.05 & 1.88 & 3.02 & 2.04 & 0.00 & 2.88 & 4.45 \\
\hline 10-12 months & 23.94 & 2.17 & 25.97 & 30.46 & 34.64 & 36.93 & 11.36 & 25.44 & 32.69 \\
\hline Don't know/refused & 2.15 & 0.00 & 2.35 & 3.29 & 2.83 & 2.20 & 7.41 & 2.89 & 3.24 \\
\hline \multicolumn{10}{|c|}{ Total number of home visits in past 12 months } \\
\hline 1 & 7.94 & 13.49 & 7.42 & 5.20 & 5.00 & 9.32 & 7.31 & 6.85 & 5.56 \\
\hline $2-3$ & 10.38 & 14.88 & 9.96 & 7.26 & 6.35 & 5.72 & 10.27 & 10.79 & 8.96 \\
\hline $4-9$ & 29.64 & 43.45 & 28.35 & 29.28 & 24.29 & 19.90 & 24.62 & 27.31 & 23.77 \\
\hline $10+$ & 49.40 & 24.42 & 51.73 & 54.66 & 60.56 & 61.91 & 56.35 & 52.13 & 58.56 \\
\hline Don't know/refused & 2.65 & 3.76 & 2.54 & 3.60 & 3.80 & 3.16 & 1.46 & 2.92 & 3.15 \\
\hline \multicolumn{10}{|c|}{ Number of office visits in the past 12 months } \\
\hline 0 & 8.56 & 12.07 & 4.67 & 4.77 & 5.50 & 6.15 & 6.75 & 3.51 & 6.26 \\
\hline At least 1 time & 88.84 & 85.9 & 92.09 & 90.44 & 89.13 & 88.36 & 88.42 & 93.39 & 90.67 \\
\hline 1 & 9.30 & 12.43 & 5.83 & 5.30 & 5.61 & 5.34 & 10.77 & 5.22 & 6.65 \\
\hline $2-3$ & 22.01 & 27.20 & 16.26 & 13.70 & 8.79 & 10.62 & 14.24 & 14.85 & 13.55 \\
\hline $4-9$ & 37.62 & 36.03 & 39.39 & 38.90 & 35.55 & 31.16 & 32.68 & 40.32 & 38.56 \\
\hline $10+$ & 19.91 & 10.24 & 30.61 & 32.54 & 39.18 & 41.24 & 30.73 & 33.00 & 31.91 \\
\hline Don't know/refused & 2.60 & 2.03 & 3.23 & 4.78 & 5.37 & 5.49 & 4.83 & 3.11 & 3.06 \\
\hline
\end{tabular}




\begin{tabular}{|c|c|c|c|c|c|c|c|c|c|}
\hline & \multirow[b]{2}{*}{ Total } & \multirow{2}{*}{$\begin{array}{c}\text { No } \\
\text { Disability }\end{array}$} & \multirow{2}{*}{$\begin{array}{c}\text { Disability } \\
\text { At least } 1 \\
\text { of the } 6\end{array}$} & \multicolumn{2}{|c|}{ Participation Restriction } & \multirow{2}{*}{$\begin{array}{c}\begin{array}{c}\text { Activity } \\
\text { Limitation }\end{array} \\
\text { ADLs }\end{array}$} & \multicolumn{3}{|c|}{ Impairment } \\
\hline & & & & Employment & IADLs & & Mental & Physical & Sensory \\
\hline $\begin{array}{l}\text { Health care delayed due to cost in the past } \\
12 \text { months }\end{array}$ & 3.94 & 2.24 & 5.82 & 6.22 & 7.00 & 8.13 & 18.21 & 6.64 & 5.75 \\
\hline $\begin{array}{l}\text { Needed, didn't receive health care due to } \\
\text { cost (past year) }\end{array}$ & 2.71 & 1.28 & 4.30 & 4.97 & 5.86 & 5.34 & 11.49 & 4.69 & 3.62 \\
\hline $\begin{array}{l}\text { Can't afford mental care/counseling in past } \\
12 \text { months }\end{array}$ & 0.56 & 0.35 & 0.80 & 0.65 & 1.05 & 0.82 & 5.92 & 0.88 & 1.02 \\
\hline $\begin{array}{l}\text { Was in hospital overnight in the past } 12 \\
\text { months }\end{array}$ & 19.86 & 11.72 & 28.88 & 32.21 & 40.71 & 45.64 & 34.17 & 30.81 & 26.10 \\
\hline \multicolumn{10}{|l|}{ Number of nights in hospital } \\
\hline 1 & 14.85 & 21.25 & 11.97 & 11.80 & 7.14 & 7.53 & 12.02 & 11.57 & 10.79 \\
\hline $2-9$ & 58.86 & 63.03 & 56.99 & 55.33 & 50.26 & 42.17 & 51.60 & 55.69 & 54.21 \\
\hline $10-59$ & 22.56 & 13.66 & 26.56 & 26.16 & 33.90 & 41.72 & 32.17 & 28.27 & 31.12 \\
\hline $60+$ & 1.86 & 0.38 & 2.52 & 3.56 & 5.82 & 5.80 & 4.20 & 2.17 & 2.79 \\
\hline Don't know/refused & 1.88 & 1.67 & 1.97 & 3.15 & 2.89 & 2.80 & 0.00 & 2.31 & 1.10 \\
\hline $\begin{array}{l}\text { Received care } 10+\text { times in the past } 12 \\
\text { months }\end{array}$ & 21.34 & 10.30 & 33.56 & 38.89 & 48.48 & 49.44 & 36.81 & 36.73 & 32.42 \\
\hline
\end{tabular}




\begin{tabular}{|c|c|c|c|c|c|c|c|c|c|}
\hline & \multirow[b]{2}{*}{ Total } & \multirow{2}{*}{$\begin{array}{c}\text { No } \\
\text { Disability } \\
\end{array}$} & \multirow{2}{*}{$\begin{array}{c}\text { Disability } \\
\text { At least } 1 \\
\text { of the } 6 \\
\end{array}$} & \multicolumn{2}{|c|}{ Participation Restriction } & \multirow{2}{*}{$\begin{array}{c}\begin{array}{c}\text { Activity } \\
\text { Limitation }\end{array} \\
\text { ADLs }\end{array}$} & \multicolumn{3}{|c|}{ Impairment } \\
\hline & & & & Employment & IADLs & & Mental & Physical & Sensory \\
\hline \multicolumn{10}{|l|}{ All Families } \\
\hline \multicolumn{10}{|c|}{ Amount family spent on health care in past 12 months ${ }^{\text {a }}$} \\
\hline$\$ 0$ & 8.76 & 8.59 & 9.69 & 11.55 & 10.80 & 11.96 & 14.33 & 9.23 & 8.31 \\
\hline Less than $\$ 500$ & 43.39 & 45.25 & 33.50 & 31.67 & 31.89 & 32.40 & 32.81 & 31.62 & 33.73 \\
\hline$\$ 500-\$ 1,999$ & 30.12 & 30.25 & 29.42 & 28.77 & 25.49 & 22.25 & 25.61 & 29.66 & 31.20 \\
\hline$\$ 2,000-\$ 2,999$ & 7.69 & 7.06 & 11.02 & 10.91 & 11.36 & 9.51 & 10.76 & 12.37 & 9.51 \\
\hline$\$ 3,000-\$ 4,999$ & 4.22 & 3.71 & 6.95 & 7.40 & 8.97 & 8.12 & 5.95 & 7.37 & 8.07 \\
\hline$\$ 5,000$ and greater & 3.39 & 2.83 & 6.40 & 6.80 & 7.51 & 11.59 & 8.19 & 6.73 & 5.38 \\
\hline Don't know/refused & 2.42 & 2.31 & 3.02 & 2.89 & 3.97 & 4.17 & 2.35 & 3.03 & 3.79 \\
\hline \multicolumn{10}{|c|}{ Multi-person Families } \\
\hline \multicolumn{10}{|c|}{ Amount family spent on health care in past 12 months ${ }^{\text {a }}$} \\
\hline$\$ 0$ & 6.69 & 6.55 & 7.47 & 8.36 & 6.14 & 5.68 & 12.11 & 7.18 & 6.40 \\
\hline Less than $\$ 500$ & 41.16 & 42.91 & 31.43 & 28.88 & 30.55 & 31.90 & 31.41 & 29.61 & 32.24 \\
\hline$\$ 500-\$ 1,999$ & 32.57 & 32.84 & 31.09 & 30.97 & 27.47 & 25.02 & 27.20 & 31.03 & 33.29 \\
\hline$\$ 2,000-\$ 2,999$ & 8.53 & 7.92 & 11.95 & 12.31 & 13.01 & 10.61 & 11.59 & 13.54 & 9.02 \\
\hline$\$ 3,000-\$ 4,999$ & 4.70 & 4.15 & 7.80 & 8.65 & 10.73 & 9.44 & 6.06 & 8.13 & 9.14 \\
\hline$\$ 5,000$ and greater & 3.78 & 3.19 & 7.05 & 7.67 & 8.03 & 13.24 & 9.39 & 7.35 & 5.74 \\
\hline Don't know/refused & 2.57 & 2.45 & 3.21 & 3.16 & 4.08 & 4.10 & 2.24 & 3.15 & 4.17 \\
\hline \multicolumn{10}{|c|}{ Single Person Families } \\
\hline \multicolumn{10}{|c|}{ Amount family spent on health care in past 12 months ${ }^{\text {a }}$} \\
\hline$\$ 0$ & 19.73 & 19.89 & 19.08 & 21.77 & 23.79 & 31.29 & 23.30 & 17.96 & 17.42 \\
\hline Less than $\$ 500$ & 55.19 & 58.23 & 42.28 & 40.65 & 35.63 & 33.97 & 38.46 & 40.19 & 40.81 \\
\hline$\$ 500-\$ 1,999$ & 17.11 & 15.89 & 22.32 & 21.71 & 19.99 & 13.71 & 19.22 & 23.79 & 21.26 \\
\hline$\$ 2,000-\$ 2,999$ & 3.25 & 2.34 & 7.10 & 6.43 & 6.78 & 6.13 & 7.40 & 7.37 & 11.87 \\
\hline$\$ 3,000-\$ 4,999$ & 1.67 & 1.27 & 3.37 & 3.40 & 4.06 & 4.04 & 5.47 & 4.10 & 2.99 \\
\hline$\$ 5,000$ and greater & 1.35 & 0.80 & 3.66 & 3.98 & 6.09 & 6.48 & 3.37 & 4.05 & 3.70 \\
\hline Don't know/refused & 1.70 & 1.58 & 2.20 & 2.05 & 3.67 & 4.39 & 2.79 & 2.53 & 1.95 \\
\hline
\end{tabular}




\begin{tabular}{|c|c|c|c|c|c|c|c|c|c|}
\hline & \multirow[b]{2}{*}{ Total } & \multirow{2}{*}{$\begin{array}{c}\text { No } \\
\text { Disability }\end{array}$} & \multirow{2}{*}{$\begin{array}{c}\text { Disability } \\
\text { At least } 1 \\
\text { of the } 6 \\
\end{array}$} & \multicolumn{2}{|c|}{ Participation Restriction } & \multirow{2}{*}{$\begin{array}{c}\text { Activity } \\
\text { Limitation } \\
\text { ADLs } \\
\end{array}$} & \multicolumn{3}{|c|}{ Impairment } \\
\hline & & & & Employment & IADLs & & Mental & Physical & Sensory \\
\hline $\begin{array}{l}\text { No health insurance in past } 12 \text { months, if } \\
\text { currently insured }\end{array}$ & 5.33 & 5.00 & 7.08 & 6.36 & 5.72 & 4.71 & 10.58 & 6.43 & 5.60 \\
\hline \multicolumn{10}{|c|}{ Number of months without health insurance given a period without health insurance in past 12 months } \\
\hline 1-3 months & 41.54 & 42.18 & 39.13 & 39.00 & 33.22 & 52.02 & 33.68 & 42.07 & 28.70 \\
\hline 4-6 months & 27.34 & 26.83 & 29.29 & 34.10 & 39.36 & 25.75 & 29.62 & 23.50 & 37.15 \\
\hline 7-9 months & 12.37 & 12.49 & 11.91 & 11.62 & 13.33 & 0.00 & 16.68 & 12.30 & 13.01 \\
\hline 10-12 months & 18.05 & 17.63 & 19.60 & 15.15 & 13.51 & 22.23 & 20.02 & 22.02 & 21.15 \\
\hline Don't know/refused & 0.70 & 0.86 & 0.07 & 0.13 & 0.58 & 0.00 & 0.00 & 0.12 & 0.00 \\
\hline \multicolumn{10}{|l|}{ Source of health insurance } \\
\hline Private only & 71.77 & 75.93 & 49.65 & 38.78 & 28.12 & 26.82 & 34.56 & 50.43 & 54.87 \\
\hline Public only & 9.07 & 5.57 & 27.67 & 38.76 & 50.26 & 54.35 & 34.74 & 28.45 & 22.29 \\
\hline Public and private & 1.59 & 1.03 & 4.56 & 6.41 & 9.04 & 7.85 & 3.49 & 5.35 & 5.33 \\
\hline Single service plan & 0.11 & 0.08 & 0.27 & 0.29 & 0.00 & 0.00 & 0.14 & 0.33 & 0.00 \\
\hline Uninsured & 16.95 & 16.84 & 17.53 & 15.46 & 11.95 & 9.99 & 26.74 & 15.21 & 17.35 \\
\hline Unknown & 0.52 & 0.56 & 0.32 & 0.29 & 0.63 & 0.99 & 0.32 & 0.22 & 0.15 \\
\hline
\end{tabular}

a) Family medical spending excludes costs associated with insurance premiums, over-the-counter medicine, or reimbursed costs 


\begin{tabular}{|c|c|c|c|c|c|c|c|c|c|}
\hline & \multirow[b]{2}{*}{ Total } & \multirow{2}{*}{$\begin{array}{c}\text { No } \\
\text { Disability } \\
\end{array}$} & \multirow{2}{*}{$\begin{array}{c}\text { Disability } \\
\text { At least } 1 \\
\text { of the } 6 \\
\end{array}$} & \multicolumn{2}{|c|}{ Participation Restriction } & \multirow{2}{*}{$\begin{array}{c}\begin{array}{c}\text { Activity } \\
\text { Limitation }\end{array} \\
\text { ADLs } \\
\end{array}$} & \multicolumn{3}{|c|}{ Impairment } \\
\hline & & & & Employment & IADLs & & Mental & Physical & Sensory \\
\hline \multicolumn{10}{|c|}{ All Families } \\
\hline \multicolumn{10}{|c|}{ Amount family spent on health care in past 12 months ${ }^{\text {a }}$} \\
\hline$\$ 0$ & 7.68 & 8.12 & 7.20 & 7.36 & 8.09 & 10.20 & 5.41 & 7.55 & 7.53 \\
\hline Less than $\$ 500$ & 37.45 & 40.88 & 33.65 & 33.26 & 33.37 & 23.34 & 39.08 & 31.40 & 30.58 \\
\hline$\$ 500-\$ 1,999$ & 31.28 & 29.79 & 32.92 & 32.35 & 29.04 & 30.98 & 23.19 & 33.71 & 34.45 \\
\hline$\$ 2,000-\$ 2,999$ & 9.06 & 8.65 & 9.50 & 8.71 & 9.45 & 10.95 & 8.78 & 10.34 & 9.06 \\
\hline$\$ 3,000-\$ 4,999$ & 5.59 & 5.08 & 6.15 & 5.94 & 5.36 & 8.17 & 9.40 & 6.75 & 7.72 \\
\hline$\$ 5,000$ and Greater & 5.13 & 4.25 & 6.11 & 6.62 & 8.24 & 10.37 & 10.80 & 6.03 & 5.62 \\
\hline Don't know/refused & 3.81 & 3.26 & 4.46 & 5.75 & 6.46 & 5.98 & 3.35 & 4.22 & 5.03 \\
\hline \multicolumn{10}{|c|}{ Multi-person Families } \\
\hline \multicolumn{10}{|c|}{ Amount family spent on health care in past 12 months $^{a}$} \\
\hline$\$ 0$ & 5.18 & 5.44 & 4.85 & 4.06 & 3.90 & 6.87 & 4.44 & 5.18 & 5.32 \\
\hline Less than $\$ 500$ & 32.26 & 36.56 & 26.90 & 26.49 & 24.19 & 17.02 & 33.95 & 24.27 & 24.15 \\
\hline$\$ 500-\$ 1,999$ & 34.18 & 32.01 & 36.90 & 36.31 & 33.55 & 35.18 & 21.14 & 37.88 & 38.53 \\
\hline$\$ 2,000-\$ 2,999$ & 10.86 & 10.53 & 11.28 & 10.76 & 12.61 & 12.41 & 12.65 & 12.25 & 10.51 \\
\hline$\$ 3,000-\$ 4,999$ & 7.03 & 6.40 & 7.82 & 7.58 & 7.16 & 10.92 & 12.14 & 8.57 & 9.39 \\
\hline$\$ 5,000$ and Greater & 6.76 & 5.63 & 8.18 & 9.26 & 12.65 & 13.17 & 12.74 & 7.86 & 7.20 \\
\hline Don't know/refused & 3.71 & 3.44 & 4.07 & 5.53 & 5.93 & 4.43 & 2.94 & 3.99 & 4.90 \\
\hline \multicolumn{10}{|c|}{ Single Person Families } \\
\hline \multicolumn{10}{|c|}{ Amount family spent on health care in past 12 months $^{a}$} \\
\hline$\$ 0$ & 12.84 & 14.72 & 11.21 & 12.17 & 12.92 & 17.91 & 7.14 & 11.52 & 11.78 \\
\hline Less than $\$ 500$ & 48.11 & 51.53 & 45.16 & 43.10 & 43.92 & 37.96 & 48.18 & 43.34 & 42.96 \\
\hline$\$ 500-\$ 1,999$ & 25.31 & 24.35 & 26.14 & 26.60 & 23.84 & 21.21 & 26.83 & 26.73 & 26.61 \\
\hline$\$ 2,000-\$ 2,999$ & 5.34 & 4.03 & 6.48 & 5.72 & 5.81 & 7.58 & 1.89 & 7.13 & 6.28 \\
\hline$\$ 3,000-\$ 4,999$ & 2.61 & 1.82 & 3.30 & 3.56 & 3.28 & 1.83 & 4.53 & 3.71 & 4.51 \\
\hline$\$ 5,000$ and Greater & 1.78 & 0.84 & 2.59 & 2.79 & 3.17 & 3.90 & 7.35 & 2.95 & 2.59 \\
\hline Don't know/refused & 4.00 & 2.70 & 5.12 & 6.06 & 7.07 & 9.53 & 4.08 & 4.62 & 5.27 \\
\hline
\end{tabular}




\begin{tabular}{|c|c|c|c|c|c|c|c|c|c|}
\hline & \multirow[b]{2}{*}{ Total } & \multirow{2}{*}{$\begin{array}{c}\text { No } \\
\text { Disability }\end{array}$} & \multirow{2}{*}{$\begin{array}{c}\text { Disability } \\
\text { At least } 1 \\
\text { of the } 6 \\
\end{array}$} & \multicolumn{2}{|c|}{ Participation Restriction } & \multirow{2}{*}{$\begin{array}{c}\begin{array}{c}\text { Activity } \\
\text { Limitation }\end{array} \\
\text { ADLs } \\
\end{array}$} & \multirow[b]{2}{*}{ Mental } & \multicolumn{2}{|l|}{ Impairment } \\
\hline & & & & Employment & IADLs & & & Physical & Sensory \\
\hline $\begin{array}{l}\text { No health insurance in past } 12 \\
\text { months, if currently insured }\end{array}$ & 0.41 & 0.46 & 0.35 & 0.35 & 0.18 & 0.00 & 0.00 & 0.38 & 0.11 \\
\hline \multicolumn{10}{|c|}{ Number of months without health insurance given a period without health insurance in past 12 months } \\
\hline 1-3 months & 22.70 & 22.82 & 22.53 & 9.92 & 37.65 & NA & NA & 12.05 & 100.00 \\
\hline 4-6 months & 6.71 & 2.86 & 12.36 & 0.00 & 0.00 & NA & NA & 15.50 & 0.00 \\
\hline 7-9 months & 22.35 & 13.21 & 35.76 & 46.50 & 62.35 & NA & NA & 44.85 & 0.00 \\
\hline 10-12 months & 48.24 & 61.12 & 29.34 & 43.58 & 0.00 & NA & NA & 27.60 & 0.00 \\
\hline Don't know/refused & 0.00 & 0.00 & 0.00 & 0.00 & 0.00 & NA & NA & 0.00 & 0.00 \\
\hline \multicolumn{10}{|l|}{ Source of health insurance } \\
\hline Private only & 5.00 & 6.56 & 3.28 & 2.83 & 2.17 & 1.88 & 2.43 & 2.69 & 3.30 \\
\hline Public only & 37.43 & 34.90 & 40.23 & 42.61 & 50.24 & 52.73 & 42.25 & 39.79 & 37.77 \\
\hline Public and private & 56.15 & 56.85 & 55.36 & 53.38 & 46.35 & 43.79 & 51.62 & 56.53 & 57.64 \\
\hline Single service plan & 0.00 & 0.00 & 0.00 & 0.00 & 0.00 & 0.00 & 0.00 & 0.00 & 0.00 \\
\hline Uninsured & 1.14 & 1.46 & 0.78 & 0.77 & 1.07 & 1.38 & 3.71 & 0.61 & 0.80 \\
\hline Unknown & 0.25 & 0.23 & 0.28 & 0.30 & 0.18 & 0.22 & 0.00 & 0.29 & 0.49 \\
\hline
\end{tabular}

a) Family medical spending excludes costs associated with insurance premiums, over-the-counter medicine, or reimbursed costs 


\begin{tabular}{|c|c|c|c|c|c|c|c|c|c|}
\hline & \multirow[b]{2}{*}{ Total } & \multirow{2}{*}{$\begin{array}{c}\text { No } \\
\text { Disability }\end{array}$} & \multirow{2}{*}{$\begin{array}{c}\text { Disability } \\
\text { At least } 1 \\
\text { of the } 6\end{array}$} & \multicolumn{2}{|c|}{ Participation Restriction } & \multirow{2}{*}{$\begin{array}{c}\text { Activity } \\
\text { Limitation } \\
\text { ADLs } \\
\end{array}$} & \multicolumn{3}{|c|}{ Impairment } \\
\hline & & & & Employment & IADLs & & Mental & Physical & Sensory \\
\hline $\begin{array}{l}\text { Have health care problem that requires } \\
\text { special equipment }\end{array}$ & 3.07 & 0.50 & 16.76 & 24.07 & 43.01 & 55.04 & 14.80 & 23.10 & 19.91 \\
\hline Now use special equipment/assistance device & 3.34 & 0.82 & 16.72 & 23.02 & 42.65 & 52.08 & 14.68 & 22.53 & 23.48 \\
\hline Know of special equipment that would help & 1.88 & 0.48 & 9.29 & 12.87 & 24.34 & 26.47 & 10.09 & 12.58 & 15.60 \\
\hline \multicolumn{10}{|l|}{ Have difficulty without this special device } \\
\hline Always & 28.05 & 14.39 & 31.80 & 31.90 & 38.19 & 41.04 & 41.66 & 32.96 & 37.93 \\
\hline Often & 30.82 & 13.56 & 35.57 & 35.25 & 34.73 & 32.14 & 41.03 & 35.33 & 35.84 \\
\hline Sometimes & 24.54 & 33.47 & 22.09 & 21.94 & 18.91 & 14.69 & 12.80 & 22.99 & 7.44 \\
\hline Rarely & 9.36 & 19.38 & 6.60 & 7.55 & 7.31 & 9.60 & 1.50 & 5.46 & 11.60 \\
\hline Never & 5.54 & 18.03 & 2.11 & 1.09 & 0.43 & 1.63 & 0.00 & 1.46 & 5.63 \\
\hline Don't Know & 1.69 & 1.18 & 1.83 & 2.26 & 0.43 & 0.91 & 3.00 & 1.80 & 1.56 \\
\hline Ever worn a hearing aid & 0.98 & 0.41 & 4.02 & 3.11 & 3.74 & 3.02 & 1.83 & 2.63 & 29.77 \\
\hline \multicolumn{10}{|l|}{ Frequency of wearing a hearing aid } \\
\hline Always & 32.48 & 20.03 & 39.18 & 34.81 & 22.51 & 12.80 & 28.57 & 39.04 & 43.78 \\
\hline Most of the time & 11.53 & 5.81 & 14.61 & 15.55 & 33.84 & 43.91 & 11.41 & 17.52 & 14.48 \\
\hline Some of the time & 24.39 & 33.04 & 19.74 & 15.21 & 3.54 & 15.68 & 12.40 & 22.91 & 20.00 \\
\hline None of the time & 31.37 & 40.47 & 26.47 & 34.44 & 40.12 & 27.61 & 47.62 & 20.53 & 21.73 \\
\hline Don't know & 0.23 & 0.66 & 0.00 & 0.00 & 0.00 & 0.00 & 0.00 & 0.00 & 0.00 \\
\hline
\end{tabular}




\begin{tabular}{|c|c|c|c|c|c|c|c|c|c|}
\hline & \multirow[b]{2}{*}{ Total } & \multirow{2}{*}{$\begin{array}{c}\text { No } \\
\text { Disability }\end{array}$} & \multirow{2}{*}{$\begin{array}{c}\text { Disability } \\
\text { At least } 1 \\
\text { of the } 6\end{array}$} & \multicolumn{2}{|c|}{ Participation Restriction } & \multirow{2}{*}{$\begin{array}{c}\begin{array}{c}\text { Activity } \\
\text { Limitation }\end{array} \\
\text { ADLs } \\
\end{array}$} & \multicolumn{3}{|c|}{ Impairment } \\
\hline & & & & Employment & IADLs & & Mental & Physical & Sensory \\
\hline $\begin{array}{l}\text { Have health care problem that requires } \\
\text { special equipment }\end{array}$ & 18.16 & 2.14 & 35.91 & 44.60 & 67.51 & 80.80 & 37.70 & 43.12 & 36.58 \\
\hline Now use special equipment/assistance device & 18.15 & 3.21 & 34.69 & 42.78 & 61.06 & 72.09 & 37.53 & 40.36 & 40.06 \\
\hline Know of special equipment that would help & 4.08 & 1.11 & 7.37 & 9.88 & 12.56 & 15.83 & 14.71 & 8.45 & 8.35 \\
\hline \multicolumn{10}{|l|}{ Have difficulty without this special device } \\
\hline Always & 29.12 & 7.06 & 32.81 & 35.31 & 38.73 & 38.34 & 45.86 & 33.17 & 31.85 \\
\hline Often & 24.91 & 31.13 & 23.87 & 23.70 & 32.07 & 33.64 & 38.04 & 22.09 & 32.01 \\
\hline Sometimes & 33.26 & 39.43 & 32.23 & 30.08 & 22.87 & 22.92 & 10.07 & 33.25 & 26.95 \\
\hline Rarely & 4.76 & 13.85 & 3.22 & 3.00 & 1.64 & 0.44 & 1.37 & 3.32 & 1.57 \\
\hline Never & 5.59 & 8.53 & 5.09 & 3.90 & 1.00 & 0.00 & 4.65 & 4.84 & 0.00 \\
\hline Don't Know & 2.38 & 0.00 & 2.78 & 4.01 & 3.69 & 4.66 & 0.00 & 3.32 & 7.61 \\
\hline Ever worn a hearing aid & 13.61 & 6.81 & 21.14 & 16.71 & 16.57 & 17.20 & 16.10 & 16.52 & 64.42 \\
\hline \multicolumn{10}{|l|}{ Frequency of wearing a hearing aid } \\
\hline Always & 33.64 & 16.71 & 39.68 & 33.29 & 38.74 & 29.68 & 9.71 & 39.95 & 47.63 \\
\hline Most of the time & 20.87 & 22.68 & 20.22 & 18.92 & 20.47 & 18.00 & 9.18 & 19.34 & 19.44 \\
\hline Some of the time & 30.58 & 38.92 & 27.61 & 33.35 & 24.40 & 30.55 & 45.97 & 29.32 & 23.45 \\
\hline None of the time & 14.91 & 21.68 & 12.50 & 14.44 & 16.39 & 21.78 & 35.15 & 11.38 & 9.48 \\
\hline Don't know & 0.00 & 0.00 & 0.00 & 0.00 & 0.00 & 0.00 & 0.00 & 0.00 & 0.00 \\
\hline
\end{tabular}


Table 18. Estimated Population of Persons with Disabilities, by Data Source

\begin{tabular}{|c|c|c|c|c|c|c|c|c|}
\hline & \multirow[b]{2}{*}{ No Disability } & \multirow[b]{2}{*}{ Disability } & \multicolumn{2}{|c|}{ Participation Restriction } & \multirow{2}{*}{$\begin{array}{c}\begin{array}{c}\text { Activity } \\
\text { Limitation }\end{array} \\
\text { ADLs } \\
\end{array}$} & \multicolumn{3}{|c|}{ Impairment } \\
\hline & & & Work Limitation & IADL & & Mental & Physical & Sensory \\
\hline \multicolumn{9}{|l|}{ Ages 18 to 24} \\
\hline Census 2000 & $24,790,000$ & $1,442,000$ & NA & NA & 207,000 & 883,000 & 456,000 & 326,000 \\
\hline American Community Survey, 2003 & $24,194,401$ & $1,667,355$ & 714,229 & 399,423 & 187,904 & 953,448 & 535,666 & 356,820 \\
\hline Current Population Survey, March 2004 & $26,803,529$ & 816,662 & 816,662 & NA & NA & NA & NA & NA \\
\hline National Health Interview Survey, 2002 & $25,225,000$ & $2,126,000$ & 927,000 & 228,000 & 147,000 & 786,000 & 859,000 & 78,000 \\
\hline Panel Study on Income Dynamics, 2001 & $9,123,000$ & 690,000 & 690,000 & NA & NA & NA & NA & NA \\
\hline Survey of Income and Program Participation, 2002 & $24,820,000$ & $2,426,337$ & $1,209,000$ & 366,000 & 146,000 & $1,076,000$ & 982,000 & 533,000 \\
\hline \multicolumn{9}{|l|}{ Ages 25 to 61} \\
\hline Census 2000 & $124,493,000$ & $14,005,000$ & NA & NA & $2,627,000$ & $5,218,000$ & $9,447,000$ & $3,346,000$ \\
\hline American Community Survey, 2003 & $126,649,510$ & $17,146,845$ & $9,854,223$ & $4,227,427$ & $2,925,715$ & $5,745,569$ & $10,819,521$ & 3,944,388 \\
\hline Current Population Survey, March 2004 & $132,649,606$ & $12,102,093$ & $12,102,093$ & NA & NA & NA & NA & NA \\
\hline National Health Interview Survey, 2002 & $115,934,000$ & $23,192,000$ & $13,725,000$ & $3,169,000$ & $1,350,000$ & $4,627,000$ & $14,545,000$ & $2,730,000$ \\
\hline Panel Study on Income Dynamics, 2001 & $117,273,000$ & $20,054,000$ & $20,054,000$ & NA & NA & NA & NA & NA \\
\hline Survey of Income and Program Participation, 2002 & $115,900,000$ & $26,620,000$ & $14,420,000$ & $4,931,000$ & $3,362,000$ & $4,394,000$ & $18,790,000$ & $6,490,000$ \\
\hline \multicolumn{9}{|l|}{ Ages 62 to 64} \\
\hline Census 2000 & $4,806,000$ & $1,413,000$ & NA & NA & 257,000 & 348,000 & $1,134,000$ & 373,000 \\
\hline American Community Survey, 2003 & $4,941,802$ & $1,795,533$ & $1,111,762$ & 404,875 & 293,507 & 393,782 & $1,292,381$ & 455,364 \\
\hline Current Population Survey, March 2004 & $5,482,126$ & $1,278,528$ & $1,278,528$ & NA & NA & NA & NA & NA \\
\hline National Health Interview Survey, 2002 & $4,239,000$ & $2,045,000$ & $1,281,000$ & 300,000 & 127,000 & 144,000 & $1,466,000$ & 310,000 \\
\hline Panel Study on Income Dynamics, 2001 & $3,911,000$ & $1,684,000$ & $1,684,000$ & NA & NA & NA & NA & NA \\
\hline Survey of Income and Program Participation, 2002 & $3,958,000$ & $2,581,000$ & $1,496,000$ & 567,000 & 376,000 & 252,000 & $2,165,000$ & 672,000 \\
\hline
\end{tabular}

Continued 
Table 18 (continued). Estimated Population of Persons with Disabilities, by Data Source

\begin{tabular}{|c|c|c|c|c|c|c|c|c|}
\hline & \multirow[b]{2}{*}{ No Disability } & \multirow[b]{2}{*}{ Disability } & \multicolumn{2}{|c|}{ Participation Restriction } & \multirow{2}{*}{$\begin{array}{c}\begin{array}{c}\text { Activity } \\
\text { Limitation }\end{array} \\
\text { ADLs } \\
\end{array}$} & \multicolumn{3}{|c|}{ Impairment } \\
\hline & & & Work Limitation & n IADL & & Mental & Physical & Sensory \\
\hline \multicolumn{9}{|l|}{ Ages 18 to 64} \\
\hline Census 2000 & $154,091,000$ & $16,861,000$ & NA & NA & $3,093,000$ & $6,450,000$ & $11,039,000$ & $4,046,000$ \\
\hline American Community Survey, 2003 & $155,785,713$ & $20,609,733$ & $11,680,214$ & $5,031,725$ & $3,407,126$ & $7,092,799$ & $12,647,568$ & $4,756,572$ \\
\hline Current Population Survey, March 2004 & $164,935,261$ & $14,197,283$ & $14,197,283$ & NA & NA & NA & NA & NA \\
\hline National Health Interview Survey, 2002 & $145,399,000$ & $27,363,000$ & $15,934,000$ & $3,697,000$ & $1,626,000$ & $5,558,000$ & $16,871,000$ & $3,119,000$ \\
\hline Panel Study on Income Dynamics, 2001 & $130,309,000$ & $22,429,000$ & $22,429,000$ & NA & NA & NA & NA & NA \\
\hline Survey of Income and Program Participation, 2002 & $144,678,000$ & $31,627,000$ & $17,126,000$ & $5,864,000$ & $3,885,000$ & $5,723,000$ & $21,938,000$ & $7,695,000$ \\
\hline
\end{tabular}

Source: Calculations from the various Cornell StatsRRTC User Guides.

Note: (1) For the Census 2000, the disability column is represented by those persons with sensory, physical, mental, and/or self-care disabilities.

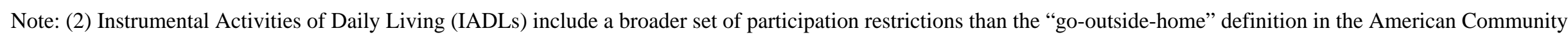
Survey. It also includes participation restrictions that affect the ability to: manage money and keep track of bills, prepare meals, and do work around the house.

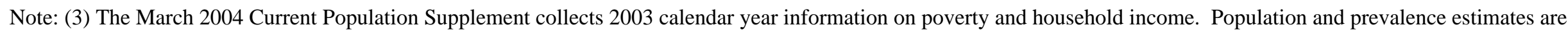
collected in March 2004.

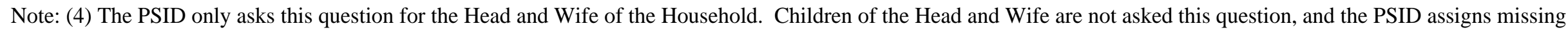
values to children for this question. As a result, the population with and without a work limitation is small relative to the other national surveys.

Note: Standard errors for NHIS estimates are in Appendix Table D-1. Standard errors for other datasets available in respective user guides. 


\begin{tabular}{|c|c|c|c|c|c|c|c|}
\hline & \multicolumn{3}{|c|}{ Participation Restriction } & \multirow{2}{*}{$\begin{array}{c}\begin{array}{c}\text { Activity } \\
\text { Limitation }\end{array} \\
\text { ADLs }\end{array}$} & \multicolumn{3}{|c|}{ Impairment } \\
\hline & Disability & Work Limitation & IADL & & Mental & Physical & Sensory \\
\hline \multicolumn{8}{|l|}{ Ages 18 to 24} \\
\hline Census 2000 & 5.5 & NA & NA & 0.8 & 3.4 & 1.7 & 1.2 \\
\hline ACS, 2003 & 6.5 & 2.8 & 1.5 & 0.7 & 3.7 & 2.1 & 1.4 \\
\hline CPS, March 2004 & 3.0 & 3.0 & NA & NA & NA & NA & NA \\
\hline NHIS, 2002 & 7.8 & 3.4 & 0.8 & 0.5 & 2.9 & 3.1 & 0.3 \\
\hline PSID, 2001 & 7.0 & 7.0 & NA & NA & NA & NA & NA \\
\hline SIPP, 2002 & 8.9 & 4.4 & 1.3 & 0.5 & 4.0 & 3.6 & 2.0 \\
\hline \multicolumn{8}{|l|}{ Ages 25 to 61} \\
\hline Census 2000 & 10.1 & NA & NA & 1.9 & 3.8 & 6.8 & 2.4 \\
\hline ACS, 2003 & 11.9 & 6.9 & 2.9 & 2.0 & 4.0 & 7.5 & 2.7 \\
\hline CPS, March 2004 & 8.4 & 8.4 & NA & NA & NA & NA & NA \\
\hline NHIS, 2002 & 16.7 & 9.9 & 2.3 & 1 & 3.3 & 10.5 & 2.0 \\
\hline PSID, 2001 & 14.6 & 14.6 & NA & NA & NA & NA & NA \\
\hline SIPP, 2002 & 18.7 & 10.1 & 3.5 & 2.4 & 3.1 & 13.2 & 4.6 \\
\hline \multicolumn{8}{|l|}{ Ages 62 to 64} \\
\hline Census 2000 & 22.7 & NA & NA & 4.1 & 5.6 & 18.2 & 6.0 \\
\hline ACS, 2003 & 26.7 & 16.5 & 6.0 & 4.4 & 5.8 & 19.2 & 6.8 \\
\hline CPS, March 2004 & 18.9 & 18.9 & NA & NA & NA & NA & NA \\
\hline NHIS, 2002 & 32.5 & 20.4 & 4.8 & 2.0 & 2.3 & 23.3 & 4.9 \\
\hline PSID, 2001 & 30.1 & 30.1 & NA & NA & NA & NA & NA \\
\hline SIPP, 2002 & 39.5 & 22.9 & 8.7 & 5.8 & 3.9 & 33.1 & 10.3 \\
\hline \multicolumn{8}{|l|}{ Ages 18 to 64} \\
\hline Census 2000 & 9.9 & NA & NA & 1.8 & 3.8 & 6.5 & 2.4 \\
\hline ACS, 2003 & 11.7 & 6.6 & 2.9 & 1.9 & 4.0 & 7.2 & 2.7 \\
\hline CPS, March 2004 & 7.9 & 7.9 & NA & NA & NA & NA & NA \\
\hline NHIS, 2002 & 15.8 & 9.2 & 2.1 & 0.9 & 3.2 & 9.8 & 1.8 \\
\hline PSID, 2001 & 14.7 & 14.7 & NA & NA & NA & NA & NA \\
\hline SIPP, 2002 & 17.9 & 9.7 & 3.3 & 2.2 & 3.2 & 12.4 & 4.4 \\
\hline
\end{tabular}

Source: Calculations from the various Cornell StatsRRTC User Guides.

Note: (1) For the Census 2000, the disability column is represented by those persons with sensory, physical, mental, and/or self-care disabilities.

Note: (2) Instrumental Activities of Daily Living (IADLs) include a broader set of participation restrictions than the "go-outsidehome" definition in the American Community Survey. It also includes participation restrictions that affect the ability to: manage money and keep track of bills, prepare meals, and do work around the house.

Note: (3) The March 2004 Current Population Supplement collects 2003 calendar year information on poverty and household income. Population and prevalence estimates are collected in March 2004.

Note: (4) The PSID only asks this question for the Head and Wife of the Household. Children of the Head and Wife are not asked this question, and the PSID assigns missing values to children for this question. As a result, the population with and without a work limitation is small relative to the other national surveys.

Note: Standard errors for NHIS estimates are in Appendix Table D-1. Standard errors for other datasets available in respective user guides. 
Table 20. Estimated Employment Rates for Persons With Disabilities Ages 25 to 61, By Data Source

\begin{tabular}{|c|c|c|c|c|c|c|c|c|}
\hline & \multirow[b]{2}{*}{ No Disability } & \multirow[b]{2}{*}{ Disability } & \multicolumn{2}{|c|}{ Participation Restriction } & \multirow{2}{*}{$\begin{array}{c}\begin{array}{c}\text { Activity } \\
\text { Limitation }\end{array} \\
\text { ADLs } \\
\end{array}$} & \multicolumn{3}{|c|}{ Impairment } \\
\hline & & & Work Limitation & IADL & & Mental & Physical & Sensory \\
\hline \multicolumn{9}{|c|}{ Reference Week, Ages 25 to 61} \\
\hline Census 2000 & 78.8 & 41.8 & NA & NA & 21.7 & 30.2 & 35.6 & 52.1 \\
\hline ACS, 2003 & 79.5 & 39.3 & 18.9 & 17.9 & 18.3 & 28.2 & 33.8 & 49.9 \\
\hline CPS, March 2004 & 81.4 & 19.6 & 19.6 & NA & NA & NA & NA & NA \\
\hline NHIS, 2002 & 83.3 & 47.3 & 29.8 & 18.3 & 14.1 & 37.1 & 43.8 & 58.6 \\
\hline PSID, 2001 & 83.8 & 53.2 & 53.2 & NA & NA & NA & NA & NA \\
\hline SIPP, 2002 & 82.4 & 48.9 & 27.7 & 20.3 & 22.8 & 37 & 46.4 & 53.5 \\
\hline \multicolumn{9}{|c|}{ Some Attachment, Ages 25 to 61} \\
\hline Census 2000 & 86.3 & 51.9 & NA & NA & 31.9 & 40.4 & 45.4 & 61.1 \\
\hline ACS, 2003 & 87.1 & 48.9 & 28.3 & 25.8 & 26.2 & 37.2 & 42.8 & 58.1 \\
\hline CPS, March 2004 & 86.2 & 27.9 & 27.9 & NA & NA & NA & NA & NA \\
\hline NHIS, 2002 & 88.3 & 57.9 & 42 & 25.7 & 19.9 & 51.8 & 53.8 & 66.6 \\
\hline PSID, 2001 & 91.9 & 67.8 & 67.8 & NA & NA & NA & NA & NA \\
\hline SIPP, 2002 & 90.6 & 61.1 & 41 & 34.1 & 38.8 & 46.3 & 59 & 63.7 \\
\hline \multicolumn{9}{|c|}{ Full-Year Full- Time, Ages 25 to 61} \\
\hline Census 2000 & 58.8 & 27.1 & NA & NA & 13.1 & 16.7 & 22.6 & 37.4 \\
\hline ACS, 2003 & 59.6 & 24.5 & 9.1 & 9 & 9.4 & 15 & 20.3 & 34.5 \\
\hline CPS, March 2004 & 65.3 & 9.4 & 9.4 & NA & NA & NA & NA & NA \\
\hline NHIS, 2002 & 62.8 & 29.8 & 16.3 & 9.3 & 6.2 & 21.3 & 27.2 & 43.4 \\
\hline PSID, 2001 & 70.5 & 45.1 & 45.1 & NA & NA & NA & NA & NA \\
\hline SIPP, 2002 & 58.1 & 31.2 & 15.3 & 12 & 15 & 20.3 & 29.6 & 35.6 \\
\hline
\end{tabular}

Source: Calculations from the various Cornell StatsRRTC User Guides.

Note: (1) For the Census 2000, the disability column is represented by those persons with sensory, physical, mental, and/or self-care disabilities.

Note: (2) Instrumental Activities of Daily Living (IADLs) include a broader set of participation restrictions than the "go-outside-home" definition in the American

Community Survey. It also includes participation restrictions that affect the ability to: manage money and keep track of bills, prepare meals, and do work around the house.

Note: (3) The March 2004 Current Population Supplement collects 2003 calendar year information on poverty and household income. Population and prevalence estimates are collected in March 2004.

Note: (4) The PSID only asks this question for the Head and Wife of the Household. Children of the Head and Wife are not asked this question, and the PSID assigns missing values to children for this question. As a result, the population with and without a work limitation is small relative to the other national surveys.

Note: Standard errors for NHIS estimates are in Appendix Table D-3. Standard errors for other datasets available in respective user guides. 
Table 21. Economic Well Being Estimates for Persons with Disabilities Ages 25 to 61, By Data Source

\begin{tabular}{|c|c|c|c|c|c|c|c|c|}
\hline & \multirow[b]{2}{*}{ No Disability } & \multirow[b]{2}{*}{ Disability } & \multicolumn{2}{|c|}{ Participation Restriction } & \multirow{2}{*}{$\begin{array}{c}\begin{array}{c}\text { Activity } \\
\text { Limitation }\end{array} \\
\text { ADLs } \\
\end{array}$} & \multicolumn{3}{|c|}{ Impairment } \\
\hline & & & Work Limitation & IADL & & Mental & Physical & Sensory \\
\hline \multicolumn{9}{|c|}{ Poverty Rates, Ages 25 to 61} \\
\hline Census 2000 & 7.9 & 23.2 & NA & NA & 30.0 & 30.6 & 24.2 & 20.1 \\
\hline ACS, 2003 & 7.7 & 23.7 & 29.6 & 29.7 & 28.9 & 30.8 & 25.0 & 20.8 \\
\hline CPS, March 2004 & 8.0 & 28.8 & 28.8 & NA & NA & NA & NA & NA \\
\hline NHIS, 2002 & 7.5 & 21.2 & 26.5 & 32.3 & 30.1 & 29.8 & 22.1 & 20.7 \\
\hline PSID, 2001 & 4.6 & 11.8 & 11.8 & NA & NA & NA & NA & NA \\
\hline SIPP, 2002 & 6.5 & 18.8 & 26.0 & 26.3 & 25.1 & 24.9 & 19.1 & 17.6 \\
\hline \multicolumn{9}{|c|}{ Median Household Income, Ages 25 to 61} \\
\hline Census 2000 & $\$ 56,860$ & $\$ 33,600$ & NA & NA & $\$ 27,200$ & $\$ 26,170$ & $\$ 32,000$ & $\$ 37,400$ \\
\hline ACS, 2003 & $\$ 60,000$ & $\$ 34,600$ & $\$ 28,000$ & $\$ 28,600$ & $\$ 28,000$ & $\$ 27,400$ & $\$ 32,100$ & $\$ 38,000$ \\
\hline CPS, March 2004 & $\$ 61,999$ & $\$ 27,955$ & $\$ 27,955$ & NA & NA & NA & NA & NA \\
\hline NHIS, 2002 & $\begin{array}{l}\$ 55,000- \\
\$ 64,000\end{array}$ & $\begin{array}{l}\$ 25,000 \text { - } \\
\$ 34,999\end{array}$ & $\begin{array}{l}\$ 25,000 \text { - } \\
\$ 34,999\end{array}$ & $\begin{array}{l}\$ 20,000 \text { - } \\
\$ 24,999\end{array}$ & $\begin{array}{l}\$ 20,000 \text { - } \\
\$ 24,999\end{array}$ & $\begin{array}{l}\$ 20,000- \\
\$ 24,999\end{array}$ & $\begin{array}{l}\$ 25,000- \\
\$ 34,999\end{array}$ & $\begin{array}{l}\$ 35,000- \\
\$ 44,999\end{array}$ \\
\hline PSID, 2001 & $\$ 62,000$ & $\$ 42,000$ & $\$ 42,000$ & NA & NA & NA & NA & NA \\
\hline SIPP, 2002 & $\$ 53,313$ & $\$ 33,895$ & $\$ 25,664$ & $\$ 24,989$ & $\$ 26,735$ & $\$ 26,218$ & $\$ 33,490$ & $\$ 33,776$ \\
\hline \multicolumn{9}{|c|}{ Median Size-Adjusted Household Income, Ages 25 to 61} \\
\hline Census 2000 & $\$ 33,234$ & $\$ 20,412$ & NA & NA & $\$ 16,330$ & $\$ 16,000$ & $\$ 19,676$ & $\$ 22,617$ \\
\hline ACS, 2003 & $\$ 35,796$ & $\$ 21,304$ & $\$ 17,487$ & $\$ 17,615$ & $\$ 17,667$ & $\$ 17,321$ & $\$ 20,207$ & $\$ 23,415$ \\
\hline CPS, March 2004 & $\$ 36,770$ & $\$ 17,967$ & $\$ 17,967$ & NA & NA & NA & NA & NA \\
\hline NHIS, 2002 & NA & NA & NA & NA & NA & NA & NA & NA \\
\hline PSID, 2001 & $\$ 38,891$ & $\$ 28,000$ & $\$ 28,000$ & NA & NA & NA & NA & NA \\
\hline SIPP, 2002 & NA & NA & NA & NA & NA & NA & NA & NA \\
\hline
\end{tabular}

Source: Calculations from the various Cornell StatsRRTC User Guides.

Note: (1) For the Census 2000, the disability column is represented by those persons with sensory, physical, mental, and/or self-care disabilities.

Note: (2) Instrumental Activities of Daily Living (IADLs) include a broader set of participation restrictions than the "go-outside-home" definition in the American Community Survey. It also includes participation restrictions that affect the ability to: manage money and keep track of bills, prepare meals, and do work around the house.

Note: (3) The March 2004 Current Population Supplement collects 2003 calendar year information on poverty and household income. Population and prevalence estimates are collected in March 2004.

Note: (4) The PSID only asks this question for the Head and Wife of the Household. Children of the Head and Wife are not asked this question, and the PSID assigns missing values to children for this question. As a result, the population with and without a work limitation is small relative to the other national surveys.

Note: Standard errors for NHIS estimates are in Appendix Table D-4. Standard errors for other datasets available in respective user guides. 


\section{Appendix A. Imputed Income in the NHIS ${ }^{19}$}

Relative to some other surveys, such as the CPS, the NHIS has little information on income, earnings, and wealth. The primary source of financial data in the NHIS is derived from three questions, FIN.250, FIN.260, and FIN.270. FIN.250 first asks persons: "Now I am going to ask about the total combined income ffor you/of your family in \{last year in four digit format , including income from all sources we have just talked about, including wages, salaries, Social Security or retirement benefits, help from relatives and so forth. Can you tell me that amount before taxes?” Respondents that cannot answer this question are then asked FIN. 260, which asks persons to indicate if their total combined family income is above or below $\$ 20,000$. Respondents that can answer FIN.260 are presented with a list of income groups (depending on their answer to FIN.260) and asked to choose the income group that best represents their family’s total combined income in the previous year.

The response rate for exact family income in the NHIS is low. Between 1997 and 2003, the weighted percentage of persons who reported exact family incomes ranged between 24 and 33 percent. In the same years, an additional 20 to 31 percent of the respondents reported a detailed categorical value for family income, and another 6 to 10 percent reported the two-category income range only (i.e. above or below $\$ 20,000$ ). To handle the issue of unknown and incomplete response for family income, NCHS began imputing values for family income for all families in the NHIS. Currently, imputed income is available for years 1997 through 2003. Due to additional variability associated with the multiple imputation procedure, NCHS released five distinct datasets containing imputed family income data. The purpose of producing multiple datasets is to allow for alternative methods of computing variability due to sampling error rather than the standard method for computing standard errors.

In deriving the point estimates found in Table 4, we first analyzed each of the five datasets separately to determine the poverty ratios and median income ranges for given demographic groups. A complete description of the estimates, by imputed income

${ }^{19}$ Information from this section was derived from NCHS (2005). 
dataset, can be found in Table A-3. We then calculated the simple average of the values from each of the five datasets, and reported this average in Table 4.

In the public dataset, NCHS does not release exact values for poverty ratios or family income. Instead, family income is reported in 11 income categories, and poverty ratios are reported in 14 poverty ratio categories. In the public dataset, the value for family income is reported as a one or two-digit code corresponding to an income range. Since Table 4 presents the mean value of five median income ranges, in some cases the mean value of the median family income for a particular demographic group did not correspond to a whole number. As it is difficult to interpret the partial value of an income range, we simply rounded the mean value to the nearest whole number, and reported the corresponding income range. Researchers concerned with more precise estimates of family income range may analyze the results presented in appendix Table A-3. 


\section{Appendix B. Sampling Structure and Variance Estimation}

The NHIS is based on a complex sample design incorporating stratification, clustering, and multistage sampling. As mentioned earlier in the text, the purpose of multi-stage, clustered sampling is to achieve greater administrative efficiency and to keep survey operations manageable and cost-effective.

In the development of the 2002 NHIS sample, the target universe was partitioned into 1,995 primary sampling units (PSUs). A PSU is a county, group of adjacent counties (or equivalent jurisdiction such as a parish), and/or metropolitan areas. PSUs are separated into two groups: self-representing (SR) and non-self representing (NSR) PSUs. The 52 PSUs with the largest metropolitan populations were designated as SR PSUs. SR PSUs are sampled with certainty, while the NSR PSUs are sampled for data collection with probabilities proportional to population size. The PSUs were then partitioned into 194 design strata. PSUs were first stratified by state and metropolitan status (i.e. metro or non-metro). If a given NSR contained a large population, it was further stratified by aggregate poverty rates. No PSU was allowed to comprise more than 50 percent of a stratum's total size. Because of this constraint, 43 additional PSUs were designated as NR PSUs after the initial stratification process, making 95 SR PSUs.

At this point, there were 237 strata, 95 strata containing a SR PSU and 142 containing NSR PSUs. Of the 142 NSR strata, two PSUs were drawn from 121 of the strata. For 21 of the NSR strata, the total population (estimated 1995) was so small that only a single PSU was drawn. A total of 358 PSUs were identified in this way (95 SR PSUs, in addition to 142 NSR PSUs from 121 strata with two sampled PSUs and 21 NSR PSUs from strata with only a single sampled PSU). Each of the 358 selected PSUs was then stratified into Census blocks or combinations of Census blocks based on concentrations of black and/or Hispanic residents, as determined from the 1990 Decennial Census. The maximum number of substrata within a PSU was 21; metropolitan PSUs (SR PSU) tended to have more substrata. Sampling within each substratum is complex, and is done from a universe of Secondary Sampling Units (SSUs). SSUs are sampled to represent each substratum. 
Within each selected SSU, all households containing black and/or Hispanic individuals are selected for interview. Other households are selected at different rates within each substratum. All members of each selected household are sampled in the family core section of the survey, and one adult and child are each sampled for the sample adult core and sample child core, respectively. For additional information on the PSU stratification process, see NCHS (1999). 
Appendix C. Estimated Standard Errors

Table A-1. Standard Errors for Population and Prevalence Estimates by Disability Concept Estimates

\begin{tabular}{|c|c|c|c|c|c|c|c|c|}
\hline & \multirow{2}{*}{$\begin{array}{c}\text { No } \\
\text { Disability }\end{array}$} & \multirow{2}{*}{$\begin{array}{c}\text { Disability } \\
\text { At least } 1 \\
\text { of the } 6 \\
\end{array}$} & \multicolumn{2}{|c|}{ Participation Restriction } & \multicolumn{2}{|l|}{$\begin{array}{c}\text { Activity } \\
\text { Limitation }\end{array}$} & \multicolumn{2}{|l|}{ Impairment } \\
\hline & & & Limitation & IADLs & ADLs & Mental & Physical & Sensory \\
\hline \multicolumn{9}{|l|}{ All, Age 18-99 } \\
\hline Population Estimate & $1,755,092.0$ & $829,093.0$ & $581,476.9$ & $252,802.9$ & $183,966.4$ & $240,574.5$ & $629,540.5$ & $265,429.9$ \\
\hline Prevalence Rate & 0.33 & 0.33 & 0.24 & 0.12 & 0.09 & 0.11 & 0.26 & 0.13 \\
\hline \multicolumn{9}{|l|}{ Ages 5 to 17} \\
\hline Population Estimate & NA & NA & NA & NA & NA & NA & NA & NA \\
\hline Prevalence Rate & NA & NA & NA & NA & NA & NA & NA & NA \\
\hline \multicolumn{9}{|l|}{ Ages 18 to 24} \\
\hline Population Estimate & $753,933.5$ & $152,033.3$ & $105,648.8$ & $54,120.4$ & $46,930.0$ & $92,344.0$ & $94,508.0$ & 22,988.0 \\
\hline Prevalence Rate & 0.55 & 0.55 & 0.38 & 0.20 & 0.17 & 0.34 & 0.34 & 0.08 \\
\hline \multicolumn{9}{|l|}{ Ages 25 to 61} \\
\hline Population Estimate & $1,405,058.0$ & $567,249.8$ & $432,850.3$ & $169,537.0$ & $111,625.9$ & $198,903.9$ & $436,408.0$ & $170,720.0$ \\
\hline Prevalence Rate & 0.35 & 0.36 & 0.28 & 0.12 & 0.08 & 0.14 & 0.29 & 0.12 \\
\hline \multicolumn{9}{|l|}{ Ages 62 to 64} \\
\hline Population Estimate & $188,350.1$ & $124,511.3$ & $96,838.2$ & $43,712.5$ & $27,898.0$ & $28,717.8$ & $105,554.5$ & $51,851.9$ \\
\hline Prevalence Rate & 1.70 & 1.70 & 1.44 & 0.69 & 0.44 & 0.45 & 1.51 & 0.80 \\
\hline \multicolumn{9}{|l|}{ Ages 65 and older } \\
\hline Population Estimate & $421,357.3$ & $432,684.3$ & $293,098.3$ & $168,875.4$ & $131,157.0$ & $74,373.7$ & $328,689.8$ & $186,519.5$ \\
\hline Prevalence Rate & 0.79 & 0.80 & 0.74 & 0.46 & 0.37 & 0.22 & 0.70 & 0.52 \\
\hline
\end{tabular}


Table A-2. Standard Errors for Demographic Characteristics by Component of Disability Process

\begin{tabular}{|c|c|c|c|c|c|c|c|c|}
\hline \multirow[b]{2}{*}{ Characteristic } & \multirow{2}{*}{$\begin{array}{c}\text { No } \\
\text { Disability }\end{array}$} & \multirow{2}{*}{$\begin{array}{c}\text { Disability } \\
\text { At least } 1 \\
\text { of the } 6 \\
\end{array}$} & \multicolumn{2}{|c|}{ Participation Restriction } & \multirow{2}{*}{$\begin{array}{c}\text { Activity } \\
\text { Limitation } \\
\text { ADLs } \\
\end{array}$} & \multirow[b]{2}{*}{ Mental } & \multicolumn{2}{|c|}{ Impairment } \\
\hline & & & Limitation & IADLs & & & Physical & Sensory \\
\hline \multicolumn{9}{|l|}{ Age } \\
\hline$\% 18$ to 24 & 0.409 & 0.344 & 0.428 & 0.690 & 1.260 & 1.332 & 0.330 & 0.328 \\
\hline$\% 25$ to 34 & 0.320 & 0.360 & 0.465 & 0.664 & 1.328 & 1.153 & 0.369 & 0.776 \\
\hline$\% 35$ to 44 & 0.339 & 0.493 & 0.694 & 1.038 & 1.350 & 1.627 & 0.555 & 1.052 \\
\hline$\% 45$ to 54 & 0.324 & 0.573 & 0.844 & 1.205 & 1.649 & 1.751 & 0.738 & 1.132 \\
\hline$\% 55$ to 64 & 0.235 & 0.560 & 0.733 & 1.105 & 1.579 & 1.188 & 0.661 & 1.349 \\
\hline$\% 65$ to 74 & 0.193 & 0.503 & 0.627 & 1.060 & 1.545 & 0.906 & 0.613 & 1.311 \\
\hline$\% 75$ to 84 & 0.129 & 0.513 & 0.644 & 1.240 & 2.035 & 0.676 & 0.605 & 1.452 \\
\hline \% 85 or older & 0.044 & 0.277 & 0.363 & 1.067 & 1.629 & 0.372 & 0.354 & 1.123 \\
\hline \multicolumn{9}{|l|}{ Gender } \\
\hline$\%$ Male & 0.408 & 0.780 & 0.987 & 1.481 & 2.365 & 1.921 & 0.900 & 1.771 \\
\hline \% Female & 0.408 & 0.780 & 0.987 & 1.481 & 2.365 & 1.921 & 0.900 & 1.771 \\
\hline \multicolumn{9}{|l|}{ Race } \\
\hline \% White & 0.410 & 0.692 & 0.823 & 1.258 & 2.229 & 1.566 & 0.777 & 1.020 \\
\hline$\%$ Black & 0.363 & 0.594 & 0.710 & 1.000 & 1.980 & 1.314 & 0.674 & 0.804 \\
\hline \% Native American & 0.077 & 0.161 & 0.205 & 0.371 & 0.506 & 0.356 & 0.190 & 0.514 \\
\hline$\%$ Asian & 0.194 & 0.215 & 0.284 & 0.539 & 1.023 & 0.695 & 0.258 & 0.383 \\
\hline \% Some Other Race & 0.141 & 0.191 & 0.203 & 0.432 & 0.782 & 0.547 & 0.226 & 0.328 \\
\hline \% Multiple race & 0.033 & 0.036 & 0.050 & 0.133 & 0.230 & 0.157 & 0.051 & 0.000 \\
\hline \multicolumn{9}{|l|}{ Ethnicity } \\
\hline \% Hispanic & 0.298 & 0.381 & 0.453 & 0.807 & 1.409 & 1.152 & 0.432 & 0.655 \\
\hline \multicolumn{9}{|l|}{ Education } \\
\hline \% Less than High School & 0.300 & 0.643 & 0.836 & 1.404 & 2.294 & 1.636 & 0.749 & 1.505 \\
\hline \% High School/GED & 0.418 & 0.685 & 0.932 & 1.529 & 2.519 & 1.978 & 0.787 & 1.578 \\
\hline \% Some College & 0.376 & 0.603 & 0.768 & 1.202 & 1.840 & 1.462 & 0.705 & 1.422 \\
\hline $\begin{array}{l}\text { \% Four Year College } \\
\text { Graduate or more }\end{array}$ & 0.441 & 0.461 & 0.572 & 0.897 & 1.524 & 1.189 & 0.579 & 1.263 \\
\hline Don't know/refused & 0.118 & 0.181 & 0.269 & 0.580 & 0.872 & 0.297 & 0.214 & 0.537 \\
\hline Total & 0.329 & 0.329 & 0.243 & 0.118 & 0.085 & 0.114 & 0.267 & 0.127 \\
\hline
\end{tabular}

Source: Author's calculations from 2002 National Health Interview Survey (NHIS) 
Table A-3. Economic Well Being Measures, Ages 25 to 61, by NHIS Income Imputation File

\begin{tabular}{|c|c|c|c|c|c|c|c|c|c|}
\hline & \multirow[b]{2}{*}{ Total } & \multirow[b]{2}{*}{ No Disability } & \multirow{2}{*}{$\begin{array}{c}\text { Disability } \\
\text { At least } 1 \\
\text { of the } 6 \\
\end{array}$} & \multicolumn{2}{|c|}{ Participation Restriction } & \multirow{2}{*}{$\begin{array}{c}\begin{array}{c}\text { Activity } \\
\text { Limitation }\end{array} \\
\text { ADLs } \\
\end{array}$} & \multicolumn{3}{|c|}{ Impairment } \\
\hline & & & & Limitation & IADLs & & Mental & Physical & Sensory \\
\hline \multicolumn{10}{|c|}{, } \\
\hline \% Below Poverty Line & 9.9 & 7.7 & 21.2 & 26.6 & 31.7 & 29.2 & 30.6 & 22.1 & 20.4 \\
\hline \% Below Poverty Line & 9.3 & 7.5 & 21.3 & 26.8 & 32.6 & 31.3 & 29.5 & 22.2 & 20.1 \\
\hline \% Below Poverty Line & 9.8 & 7.4 & 21.4 & 26.9 & 33.0 & 29.7 & 30.1 & 22.3 & 21.7 \\
\hline \% Below Poverty Line & 9.8 & 7.6 & 21.2 & 26.3 & 31.7 & 29.2 & 29.3 & 21.9 & 21.7 \\
\hline \% Below Poverty Line & 9.7 & 7.5 & 20.9 & 26.2 & 32.6 & 31.3 & 29.3 & 22.2 & 19.5 \\
\hline Median Household Income & $\begin{array}{c}\$ 45,000- \\
54,999\end{array}$ & $\begin{array}{c}\$ 55,000- \\
64,999\end{array}$ & $\begin{array}{c}\$ 25,000- \\
34,999\end{array}$ & $\begin{array}{c}\$ 25,000- \\
34,999\end{array}$ & $\begin{array}{c}\$ 20,000- \\
24,999\end{array}$ & $\begin{array}{c}\$ 20,000- \\
24,999\end{array}$ & $\begin{array}{c}\$ 20,000- \\
24,999\end{array}$ & $\begin{array}{c}\$ 25,000- \\
34,999\end{array}$ & $\begin{array}{c}\$ 35,000- \\
44,999\end{array}$ \\
\hline Median Household Income & $\begin{array}{c}\$ 45,000- \\
54,999\end{array}$ & $\begin{array}{c}\$ 55,000- \\
64,999\end{array}$ & $\begin{array}{c}\$ 25,000- \\
34,999\end{array}$ & $\begin{array}{c}\$ 25,000- \\
34,999\end{array}$ & $\begin{array}{c}\$ 20,000- \\
24,999\end{array}$ & $\begin{array}{c}\$ 20,000- \\
24,999\end{array}$ & $\begin{array}{c}\$ 20,000- \\
24,999\end{array}$ & $\begin{array}{c}\$ 25,000- \\
34,999\end{array}$ & $\begin{array}{c}\$ 35,000- \\
44,999\end{array}$ \\
\hline Median Household Income & $\begin{array}{c}\$ 45,000- \\
54,999\end{array}$ & $\begin{array}{c}\$ 55,000- \\
64,999\end{array}$ & $\begin{array}{c}\$ 25,000- \\
34,999\end{array}$ & $\begin{array}{c}\$ 25,000- \\
34,999\end{array}$ & $\begin{array}{c}\$ 20,000- \\
24,999\end{array}$ & $\begin{array}{c}\$ 20,000- \\
24,999\end{array}$ & $\begin{array}{c}\$ 20,000- \\
24,999\end{array}$ & $\begin{array}{c}\$ 25,000- \\
34,999\end{array}$ & $\begin{array}{c}\$ 35,000- \\
44,999\end{array}$ \\
\hline Median Household Income & $\begin{array}{c}\$ 45,000- \\
54,999\end{array}$ & $\begin{array}{c}\$ 55,000- \\
64,999\end{array}$ & $\begin{array}{c}\$ 25,000- \\
34,999\end{array}$ & $\begin{array}{c}\$ 25,000- \\
34,999\end{array}$ & $\begin{array}{c}\$ 20,000- \\
24,999\end{array}$ & $\begin{array}{c}\$ 20,000- \\
24,999\end{array}$ & $\begin{array}{c}\$ 25,000- \\
34,999\end{array}$ & $\begin{array}{c}\$ 25,000- \\
34,999\end{array}$ & $\begin{array}{c}\$ 35,000- \\
44,999\end{array}$ \\
\hline Median Household Income & $\begin{array}{c}\$ 45,000- \\
54,999\end{array}$ & $\begin{array}{c}\$ 55,000- \\
64,999\end{array}$ & $\begin{array}{c}\$ 25,000- \\
34,999\end{array}$ & $\begin{array}{c}\$ 25,000- \\
34,999\end{array}$ & $\begin{array}{c}\$ 20,000- \\
24,999\end{array}$ & $\begin{array}{c}\$ 20,000- \\
24,999\end{array}$ & $\begin{array}{c}\$ 20,000- \\
24,999\end{array}$ & $\begin{array}{c}\$ 25,000- \\
34,999\end{array}$ & $\begin{array}{c}\$ 35,000- \\
44,999\end{array}$ \\
\hline \multicolumn{10}{|l|}{ Men } \\
\hline \% Below Poverty Line & 8.4 & 6.7 & 18.7 & 23.8 & 30.3 & 27.1 & 25.5 & 20.5 & 12.8 \\
\hline \% Below Poverty Line & 8.4 & 6.6 & 19.1 & 24.7 & 31.4 & 30.5 & 25.1 & 20.7 & 14.2 \\
\hline \% Below Poverty Line & 8.3 & 6.4 & 19.1 & 23.9 & 32.7 & 27.2 & 25.0 & 20.7 & 15.3 \\
\hline \% Below Poverty Line & 8.4 & 6.6 & 19.0 & 23.9 & 32.7 & 28.1 & 24.7 & 20.0 & 15.0 \\
\hline \% Below Poverty Line & 8.3 & 6.5 & 18.8 & 23.7 & 31.5 & 30.1 & 25.6 & 21.1 & 12.6 \\
\hline Median Household Income & $\begin{array}{c}\$ 45,000- \\
54,999\end{array}$ & $\begin{array}{c}\$ 55,000- \\
64,999\end{array}$ & $\begin{array}{c}\$ 25,000- \\
34,999\end{array}$ & $\begin{array}{c}\$ 25,000- \\
34,999\end{array}$ & $\begin{array}{c}\$ 20,000- \\
24,999\end{array}$ & $\begin{array}{c}\$ 20,000- \\
24,999\end{array}$ & $\begin{array}{c}\$ 25,000- \\
34,999\end{array}$ & $\begin{array}{c}\$ 25,000- \\
34,999\end{array}$ & $\begin{array}{c}\$ 35,000- \\
44,999\end{array}$ \\
\hline Median Household Income & $\begin{array}{c}\$ 55,000- \\
64,999\end{array}$ & $\begin{array}{c}\$ 55,000- \\
64,999\end{array}$ & $\begin{array}{c}\$ 25,000- \\
34,999\end{array}$ & $\begin{array}{c}\$ 25,000- \\
34,999\end{array}$ & $\begin{array}{c}\$ 20,000- \\
24,999\end{array}$ & $\begin{array}{c}\$ 20,000- \\
24,999\end{array}$ & $\begin{array}{c}\$ 25,000- \\
34,999\end{array}$ & $\begin{array}{c}\$ 25,000- \\
34,999\end{array}$ & $\begin{array}{c}\$ 35,000- \\
44,999\end{array}$ \\
\hline Median Household Income & $\begin{array}{c}\$ 45,000- \\
54,999\end{array}$ & $\begin{array}{c}\$ 55,000- \\
64,999\end{array}$ & $\begin{array}{c}\$ 25,000- \\
34,999\end{array}$ & $\begin{array}{c}\$ 25,000- \\
34,999\end{array}$ & $\begin{array}{c}\$ 20,000- \\
24,999\end{array}$ & $\begin{array}{c}\$ 20,000- \\
24,999\end{array}$ & $\begin{array}{c}\$ 25,000- \\
34,999\end{array}$ & $\begin{array}{c}\$ 25,000- \\
34,999\end{array}$ & $\begin{array}{c}\$ 35,000- \\
44,999\end{array}$ \\
\hline Median Household Income & $\begin{array}{c}\$ 45,000- \\
54,999\end{array}$ & $\begin{array}{c}\$ 55,000- \\
64,999\end{array}$ & $\begin{array}{c}\$ 25,000- \\
34,999\end{array}$ & $\begin{array}{c}\$ 25,000- \\
34,999\end{array}$ & $\begin{array}{c}\$ 20,000- \\
24,999\end{array}$ & $\begin{array}{c}\$ 20,000- \\
24,999\end{array}$ & $\begin{array}{c}\$ 25,000- \\
34,999\end{array}$ & $\begin{array}{c}\$ 25,000- \\
34,999\end{array}$ & $\begin{array}{c}\$ 35,000- \\
44,999\end{array}$ \\
\hline Median Household Income & $\begin{array}{c}\$ 45,000- \\
54,999 \\
\end{array}$ & $\begin{array}{c}\$ 55,000- \\
64,999 \\
\end{array}$ & $\begin{array}{c}\$ 25,000- \\
34,999 \\
\end{array}$ & $\begin{array}{c}\$ 25,000- \\
34,999 \\
\end{array}$ & $\begin{array}{c}\$ 20,000- \\
24,999 \\
\end{array}$ & $\begin{array}{c}\$ 20,000- \\
24,999 \\
\end{array}$ & $\begin{array}{c}\$ 25,000- \\
34,999 \\
\end{array}$ & $\begin{array}{c}\$ 25,000- \\
34,999 \\
\end{array}$ & $\begin{array}{c}\$ 35,000- \\
44,999 \\
\end{array}$ \\
\hline
\end{tabular}


Table A-3 (continued). Economic Well Being Measures, Ages 25 to 61, by NHIS Income Imputation File

\begin{tabular}{|c|c|c|c|c|c|c|c|c|c|}
\hline & \multirow[b]{2}{*}{ Total } & \multirow[b]{2}{*}{ No Disability } & \multirow{2}{*}{$\begin{array}{c}\text { Disability } \\
\text { At least } 1 \\
\text { of the } 6\end{array}$} & \multicolumn{2}{|c|}{ Participation Restriction } & \multirow{2}{*}{$\begin{array}{c}\begin{array}{c}\text { Activity } \\
\text { Limitation }\end{array} \\
\text { ADLs }\end{array}$} & \multicolumn{3}{|c|}{ Impairment } \\
\hline & & & & Limitation & IADLs & & Mental & Physical & Sensory \\
\hline \multicolumn{10}{|l|}{ Women } \\
\hline \% Below Poverty Line & 11.4 & 8.7 & 23.2 & 28.9 & 32.7 & 31.3 & 33.9 & 23.0 & 31.9 \\
\hline \% Below Poverty Line & 11.2 & 8.5 & 23.0 & 28.5 & 33.4 & 32.0 & 32.3 & 23.1 & 29.1 \\
\hline \% Below Poverty Line & 11.2 & 8.4 & 23.1 & 29.4 & 33.2 & 32.0 & 33.4 & 23.3 & 31.4 \\
\hline \% Below Poverty Line & 11.2 & 8.5 & 22.9 & 28.3 & 31.1 & 30.3 & 32.3 & 22.9 & 31.9 \\
\hline \% Below Poverty Line & 11.1 & 8.5 & 22.6 & 28.4 & 33.4 & 32.4 & 31.7 & 22.8 & 30.0 \\
\hline Median Household Income & $\begin{array}{c}\$ 45,000- \\
54,999\end{array}$ & $\begin{array}{c}\$ 55,000- \\
64,999\end{array}$ & $\begin{array}{c}\$ 25,000- \\
34,999\end{array}$ & $\begin{array}{c}\$ 25,000- \\
34,999\end{array}$ & $\begin{array}{c}\$ 20,000- \\
24,999\end{array}$ & $\begin{array}{c}\$ 15,000- \\
19,999\end{array}$ & $\begin{array}{c}\$ 20,000- \\
24,999\end{array}$ & $\begin{array}{c}\$ 25,000- \\
34,999\end{array}$ & $\begin{array}{c}\$ 25,000- \\
34,999\end{array}$ \\
\hline Median Household Income & $\begin{array}{c}\$ 45,000- \\
54,999\end{array}$ & $\begin{array}{c}\$ 55,000- \\
64,999\end{array}$ & $\begin{array}{c}\$ 25,000- \\
34,999\end{array}$ & $\begin{array}{c}\$ 25,000- \\
34,999\end{array}$ & $\begin{array}{c}\$ 20,000- \\
24,999\end{array}$ & $\begin{array}{c}\$ 15,000- \\
19,999\end{array}$ & $\begin{array}{c}\$ 20,000- \\
24,999\end{array}$ & $\begin{array}{c}\$ 25,000- \\
34,999\end{array}$ & $\begin{array}{c}\$ 25,000- \\
34,999\end{array}$ \\
\hline Median Household Income & $\begin{array}{c}\$ 45,000- \\
54,999\end{array}$ & $\begin{array}{c}\$ 55,000- \\
64,999\end{array}$ & $\begin{array}{c}\$ 25,000- \\
34,999\end{array}$ & $\begin{array}{c}\$ 25,000- \\
34,999\end{array}$ & $\begin{array}{c}\$ 20,000- \\
24,999\end{array}$ & $\begin{array}{c}\$ 15,000- \\
19,999\end{array}$ & $\begin{array}{c}\$ 20,000- \\
24,999\end{array}$ & $\begin{array}{c}\$ 25,000- \\
34,999\end{array}$ & $\begin{array}{c}\$ 25,000- \\
34,999\end{array}$ \\
\hline Median Household Income & $\begin{array}{c}\$ 45,000- \\
54,999\end{array}$ & $\begin{array}{c}\$ 55,000- \\
64,999\end{array}$ & $\begin{array}{c}\$ 25,000- \\
34,999\end{array}$ & $\begin{array}{c}\$ 25,000- \\
34,999\end{array}$ & $\begin{array}{c}\$ 20,000- \\
24,999\end{array}$ & $\begin{array}{c}\$ 15,000- \\
19,999\end{array}$ & $\begin{array}{c}\$ 20,000- \\
24,999\end{array}$ & $\begin{array}{c}\$ 25,000- \\
34,999\end{array}$ & $\begin{array}{c}\$ 25,000- \\
34,999\end{array}$ \\
\hline Median Household Income & $\begin{array}{c}\$ 45,000- \\
54,999\end{array}$ & $\begin{array}{c}\$ 55,000- \\
64,999\end{array}$ & $\begin{array}{c}\$ 25,000- \\
34,999\end{array}$ & $\begin{array}{c}\$ 20,000- \\
24,999\end{array}$ & $\begin{array}{c}\$ 20,000- \\
24,999\end{array}$ & $\begin{array}{c}\$ 15,000- \\
19,999\end{array}$ & $\begin{array}{c}\$ 20,000- \\
24,999\end{array}$ & $\begin{array}{c}\$ 25,000- \\
34,999\end{array}$ & $\begin{array}{c}\$ 25,000- \\
34,999\end{array}$ \\
\hline \multicolumn{10}{|l|}{ White } \\
\hline \% Below Poverty Line & 8.1 & 6.2 & 18.0 & 23.5 & 27.9 & 24.1 & 28.4 & 18.7 & 16.7 \\
\hline \% Below Poverty Line & 8.0 & 6.0 & 18.1 & 23.8 & 29.2 & 26.2 & 27.7 & 18.7 & 17.3 \\
\hline \% Below Poverty Line & 8.1 & 6.0 & 18.3 & 24.0 & 29.9 & 24.7 & 27.9 & 19.0 & 17.5 \\
\hline \% Below Poverty Line & 8.0 & 6.0 & 18.0 & 23.2 & 28.3 & 25.0 & 26.7 & 18.3 & 17.5 \\
\hline \% Below Poverty Line & 7.9 & 5.9 & 17.7 & 23.2 & 29.5 & 26.0 & 27.9 & 18.3 & 15.9 \\
\hline Median Household Income & $\begin{array}{c}\$ 55,000- \\
64,999\end{array}$ & $\begin{array}{c}\$ 55,000- \\
64,999\end{array}$ & $\begin{array}{c}\$ 35,000- \\
44,999\end{array}$ & $\begin{array}{c}\$ 25,000- \\
34,999\end{array}$ & $\begin{array}{c}\$ 20,000- \\
24,999\end{array}$ & $\begin{array}{c}\$ 20,000- \\
24,999\end{array}$ & $\begin{array}{c}\$ 25,000- \\
34,999\end{array}$ & $\begin{array}{c}\$ 35,000- \\
44,999\end{array}$ & $\begin{array}{c}\$ 35,000- \\
44,999\end{array}$ \\
\hline Median Household Income & $\begin{array}{c}\$ 55,000- \\
64,999\end{array}$ & $\begin{array}{c}\$ 55,000- \\
64,999\end{array}$ & $\begin{array}{c}\$ 35,000- \\
44,999\end{array}$ & $\begin{array}{c}\$ 25,000- \\
34,999\end{array}$ & $\begin{array}{c}\$ 20,000- \\
24,999\end{array}$ & $\begin{array}{c}\$ 20,000- \\
24,999\end{array}$ & $\begin{array}{c}\$ 25,000- \\
34,999\end{array}$ & $\begin{array}{c}\$ 25,000- \\
34,999\end{array}$ & $\begin{array}{c}\$ 35,000- \\
44,999\end{array}$ \\
\hline Median Household Income & $\begin{array}{c}\$ 55,000- \\
64,999\end{array}$ & $\begin{array}{c}\$ 55,000- \\
64,999\end{array}$ & $\begin{array}{c}\$ 35,000- \\
44,999\end{array}$ & $\begin{array}{c}\$ 25,000- \\
34,999\end{array}$ & $\begin{array}{c}\$ 20,000- \\
24,999\end{array}$ & $\begin{array}{c}\$ 20,000- \\
24,999\end{array}$ & $\begin{array}{c}\$ 25,000- \\
34,999\end{array}$ & $\begin{array}{c}\$ 35,000- \\
44,999\end{array}$ & $\begin{array}{c}\$ 35,000- \\
44,999\end{array}$ \\
\hline Median Household Income & $\begin{array}{c}\$ 55,000- \\
64,999\end{array}$ & $\begin{array}{c}\$ 55,000- \\
64,999\end{array}$ & $\begin{array}{c}\$ 35,000- \\
44,999\end{array}$ & $\begin{array}{c}\$ 25,000- \\
34,999\end{array}$ & $\begin{array}{c}\$ 20,000- \\
24,999\end{array}$ & $\begin{array}{c}\$ 20,000- \\
24,999\end{array}$ & $\begin{array}{c}\$ 25,000- \\
34,999\end{array}$ & $\begin{array}{c}\$ 35,000- \\
44,999\end{array}$ & $\begin{array}{c}\$ 35,000- \\
44,999\end{array}$ \\
\hline Median Household Income & $\begin{array}{c}\$ 55,000- \\
64,999 \\
\end{array}$ & $\begin{array}{c}\$ 55,000- \\
64,999\end{array}$ & $\begin{array}{c}\$ 35,000- \\
44,999\end{array}$ & $\begin{array}{c}\$ 25,000- \\
34,999 \\
\end{array}$ & $\begin{array}{c}\$ 20,000- \\
24,999\end{array}$ & $\begin{array}{c}\$ 20,000- \\
24,999\end{array}$ & $\begin{array}{c}\$ 25,000- \\
34,999\end{array}$ & $\begin{array}{c}\$ 25,000- \\
34,999 \\
\end{array}$ & $\begin{array}{c}\$ 35,000- \\
44,999\end{array}$ \\
\hline
\end{tabular}


Table A-3 (continued). Economic Well Being Measures, Ages 25 to 61, by NHIS Income Imputation File

\begin{tabular}{|c|c|c|c|c|c|c|c|c|c|}
\hline & \multirow[b]{2}{*}{ Total } & \multirow[b]{2}{*}{ No Disability } & \multirow{2}{*}{$\begin{array}{c}\text { Disability } \\
\text { At least } 1 \\
\text { of the } 6\end{array}$} & \multicolumn{2}{|c|}{ Participation Restriction } & \multirow{2}{*}{$\begin{array}{c}\begin{array}{c}\text { Activity } \\
\text { Limitation }\end{array} \\
\text { ADLs }\end{array}$} & \multicolumn{3}{|c|}{ Impairment } \\
\hline & & & & Limitation & IADLs & & Mental & Physical & Sensory \\
\hline \multicolumn{10}{|l|}{ Black } \\
\hline \% Below Poverty Line & 18.9 & 14.8 & 36.5 & 41.4 & 51.0 & 42.1 & 36.5 & 37.0 & 39.9 \\
\hline \% Below Poverty Line & 18.9 & 14.9 & 35.7 & 41.2 & 51.0 & 45.8 & 35.7 & 37.1 & 33.5 \\
\hline \% Below Poverty Line & 18.6 & 14.5 & 35.7 & 41.1 & 49.6 & 39.7 & 39.1 & 36.9 & 39.9 \\
\hline \% Below Poverty Line & 18.5 & 14.5 & 35.4 & 40.6 & 49.7 & 40.0 & 38.1 & 36.0 & 39.9 \\
\hline \% Below Poverty Line & 19.0 & 14.9 & 36.4 & 41.9 & 50.5 & 46.4 & 35.6 & 39.6 & 43.8 \\
\hline Median Household Income & $\begin{array}{c}\$ 35,000- \\
44,999\end{array}$ & $\begin{array}{c}\$ 35,000- \\
44,999\end{array}$ & $\begin{array}{c}\$ 20,000- \\
24,999\end{array}$ & $\begin{array}{c}\$ 15,000- \\
19,999\end{array}$ & $\begin{array}{c}\$ 10,000- \\
14,999\end{array}$ & $\begin{array}{c}\$ 10,000- \\
14,999\end{array}$ & $\begin{array}{c}\$ 20,000- \\
24,999\end{array}$ & $\begin{array}{c}\$ 15,000- \\
19,999\end{array}$ & $\begin{array}{c}\$ 15,000- \\
19,999\end{array}$ \\
\hline Median Household Income & $\begin{array}{c}\$ 35,000- \\
44,999\end{array}$ & $\begin{array}{c}\$ 35,000- \\
44,999\end{array}$ & $\begin{array}{c}\$ 20,000- \\
24,999\end{array}$ & $\begin{array}{c}\$ 15,000- \\
19,999\end{array}$ & $\begin{array}{c}\$ 10,000- \\
14,999\end{array}$ & $\begin{array}{c}\$ 10,000- \\
14,999\end{array}$ & $\begin{array}{c}\$ 20,000- \\
24,999\end{array}$ & $\begin{array}{c}\$ 15,000- \\
19,999\end{array}$ & $\begin{array}{c}\$ 20,000- \\
24,999\end{array}$ \\
\hline Median Household Income & $\begin{array}{c}\$ 35,000- \\
44,999\end{array}$ & $\begin{array}{c}\$ 35,000- \\
44,999\end{array}$ & $\begin{array}{c}\$ 20,000- \\
24,999\end{array}$ & $\begin{array}{c}\$ 15,000- \\
19,999\end{array}$ & $\begin{array}{c}\$ 10,000- \\
14,999\end{array}$ & $\begin{array}{c}\$ 10,000- \\
14,999\end{array}$ & $\begin{array}{c}\$ 20,000- \\
24,999\end{array}$ & $\begin{array}{c}\$ 20,000- \\
24,999\end{array}$ & $\begin{array}{c}\$ 15,000- \\
19,999\end{array}$ \\
\hline Median Household Income & $\begin{array}{c}\$ 35,000- \\
44,999\end{array}$ & $\begin{array}{c}\$ 35,000- \\
44,999\end{array}$ & $\begin{array}{c}\$ 20,000- \\
24,999\end{array}$ & $\begin{array}{c}\$ 15,000- \\
19,999\end{array}$ & $\begin{array}{c}\$ 10,000- \\
14,999\end{array}$ & $\begin{array}{c}\$ 10,000- \\
14,999\end{array}$ & $\begin{array}{c}\$ 20,000- \\
24,999\end{array}$ & $\begin{array}{c}\$ 20,000- \\
24,999\end{array}$ & $\begin{array}{c}\$ 15,000- \\
19,999\end{array}$ \\
\hline Median Household Income & $\begin{array}{c}\$ 35,000- \\
44,999\end{array}$ & $\begin{array}{c}\$ 35,000- \\
44,999\end{array}$ & $\begin{array}{c}\$ 20,000- \\
24,999\end{array}$ & $\begin{array}{c}\$ 15,000- \\
19,999\end{array}$ & $\begin{array}{c}\$ 10,000- \\
14,999\end{array}$ & $\begin{array}{c}\$ 10,000- \\
14,999\end{array}$ & $\begin{array}{c}\$ 20,000- \\
24,999\end{array}$ & $\begin{array}{c}\$ 15,000- \\
19,999\end{array}$ & $\begin{array}{c}\$ 15,000- \\
19,999\end{array}$ \\
\hline \multicolumn{10}{|l|}{ Hispanic } \\
\hline \% Below Poverty Line & 18.9 & 17.2 & 30.4 & 37.9 & 26.9 & 36.8 & 42.8 & 30.7 & 26.1 \\
\hline \% Below Poverty Line & 18.6 & 16.7 & 31.8 & 37.1 & 29.5 & 32.6 & 43.5 & 33.2 & 30.1 \\
\hline \% Below Poverty Line & 18.6 & 16.9 & 30.4 & 37.7 & 30.5 & 36.8 & 44.1 & 30.3 & 29.7 \\
\hline \% Below Poverty Line & 19.1 & 17.2 & 32.1 & 38.2 & 27.7 & 34.1 & 42.3 & 33.5 & 29.7 \\
\hline \% Below Poverty Line & 18.6 & 16.6 & 31.5 & 37.5 & 28.6 & 41.0 & 42.4 & 31.7 & 25.3 \\
\hline Median Household Income & $\begin{array}{c}\$ 35,000- \\
44,999\end{array}$ & $\begin{array}{c}\$ 35,000- \\
44,999\end{array}$ & $\begin{array}{c}\$ 20,000- \\
24,999\end{array}$ & $\begin{array}{c}\$ 20,000- \\
24,999\end{array}$ & $\begin{array}{c}\$ 25,000- \\
34,999\end{array}$ & $\begin{array}{c}\$ 25,000- \\
34,999\end{array}$ & $\begin{array}{c}\$ 20,000- \\
24,999\end{array}$ & $\begin{array}{c}\$ 25,000- \\
34,999\end{array}$ & $\begin{array}{c}\$ 35,000- \\
44,999\end{array}$ \\
\hline Median Household Income & $\begin{array}{c}\$ 35,000- \\
44,999\end{array}$ & $\begin{array}{c}\$ 35,000- \\
44,999\end{array}$ & $\begin{array}{c}\$ 25,000- \\
34,999\end{array}$ & $\begin{array}{c}\$ 20,000- \\
24,999\end{array}$ & $\begin{array}{c}\$ 20,000- \\
24,999\end{array}$ & $\begin{array}{c}\$ 25,000- \\
34,999\end{array}$ & $\begin{array}{c}\$ 20,000- \\
24,999\end{array}$ & $\begin{array}{c}\$ 25,000- \\
34,999\end{array}$ & $\begin{array}{c}\$ 35,000- \\
44,999\end{array}$ \\
\hline Median Household Income & $\begin{array}{c}\$ 35,000- \\
44,999\end{array}$ & $\begin{array}{c}\$ 35,000- \\
44,999\end{array}$ & $\begin{array}{c}\$ 25,000- \\
34,999\end{array}$ & $\begin{array}{c}\$ 20,000- \\
24,999\end{array}$ & $\begin{array}{c}\$ 20,000- \\
24,999\end{array}$ & $\begin{array}{c}\$ 20,000- \\
24,999\end{array}$ & $\begin{array}{c}\$ 20,000- \\
24,999\end{array}$ & $\begin{array}{c}\$ 25,000- \\
34,999\end{array}$ & $\begin{array}{c}\$ 35,000- \\
44,999\end{array}$ \\
\hline Median Household Income & $\begin{array}{c}\$ 35,000- \\
44,999\end{array}$ & $\begin{array}{c}\$ 35,000- \\
44,999\end{array}$ & $\begin{array}{c}\$ 25,000- \\
34,999\end{array}$ & $\begin{array}{c}\$ 20,000- \\
24,999\end{array}$ & $\begin{array}{c}\$ 25,000- \\
34,999\end{array}$ & $\begin{array}{c}\$ 25,000- \\
34,999\end{array}$ & $\begin{array}{c}\$ 20,000- \\
24,999\end{array}$ & $\begin{array}{c}\$ 25,000- \\
34,999\end{array}$ & $\begin{array}{c}\$ 35,000- \\
44,999\end{array}$ \\
\hline Median Household Income & $\begin{array}{c}\$ 35,000- \\
44,999\end{array}$ & $\begin{array}{c}\$ 35,000- \\
44,999\end{array}$ & $\begin{array}{c}\$ 25,000- \\
34,999\end{array}$ & $\begin{array}{c}\$ 20,000- \\
24,999\end{array}$ & $\begin{array}{c}\$ 25,000- \\
34,999\end{array}$ & $\begin{array}{c}\$ 20,000- \\
24,999\end{array}$ & $\begin{array}{c}\$ 20,000- \\
24,999\end{array}$ & $\begin{array}{c}\$ 25,000- \\
34,999\end{array}$ & $\begin{array}{c}\$ 35,000- \\
44,999\end{array}$ \\
\hline
\end{tabular}


Table A-3 (continued). Economic Well Being Measures, Ages 25 to 61, by NHIS Income Imputation File

\begin{tabular}{|c|c|c|c|c|c|c|c|c|c|}
\hline & \multirow[b]{2}{*}{ Total } & \multirow[b]{2}{*}{ No Disability } & \multirow{2}{*}{$\begin{array}{c}\text { Disability } \\
\text { At least } 1 \\
\text { of the } 6 \\
\end{array}$} & \multicolumn{2}{|c|}{ Participation Restriction } & \multirow{2}{*}{$\begin{array}{c}\begin{array}{c}\text { Activity } \\
\text { Limitation }\end{array} \\
\text { ADLs }\end{array}$} & \multicolumn{3}{|c|}{ Impairment } \\
\hline & & & & Limitation & IADLs & & Mental & Physical & Sensory \\
\hline \multicolumn{10}{|l|}{ Native American } \\
\hline \% Below Poverty Line & 22.9 & 13.5 & 41.4 & 41.9 & 31.4 & 58.1 & 46.1 & 44.5 & 52.6 \\
\hline \% Below Poverty Line & 21.7 & 14.4 & 36.0 & 36.5 & 31.4 & 58.1 & 47.7 & 38.2 & 42.1 \\
\hline \% Below Poverty Line & 23.7 & 15.0 & 41.1 & 39.6 & 24.8 & 58.1 & 54.6 & 40.4 & 73.8 \\
\hline \% Below Poverty Line & 24.9 & 15.5 & 43.6 & 41.9 & 31.4 & 58.1 & 59.9 & 44.5 & 73.8 \\
\hline \% Below Poverty Line & 20.1 & 13.1 & 33.9 & 34.2 & 24.8 & 58.1 & 42.4 & 36.5 & 37.4 \\
\hline Median Household Income & $\begin{array}{c}\$ 25,000- \\
34,999\end{array}$ & $\begin{array}{c}\$ 25,000- \\
34,999\end{array}$ & $\begin{array}{c}\$ 10,000- \\
14,999\end{array}$ & $\begin{array}{c}\$ 10,000- \\
14,999\end{array}$ & $\begin{array}{c}\$ 10,000- \\
14,999\end{array}$ & $\begin{array}{c}\$ 5,000- \\
9,999\end{array}$ & $\begin{array}{c}\$ 5,000- \\
9,999\end{array}$ & $\begin{array}{c}\$ 10,000- \\
14,999\end{array}$ & $\begin{array}{c}\$ 5,000- \\
9,999\end{array}$ \\
\hline Median Household Income & $\begin{array}{c}\$ 25,000- \\
34,999\end{array}$ & $\begin{array}{c}\$ 25,000- \\
34,999\end{array}$ & $\begin{array}{c}\$ 15,000- \\
19,999\end{array}$ & $\begin{array}{c}\$ 15,000- \\
19,999\end{array}$ & $\begin{array}{c}\$ 15,000- \\
19,999\end{array}$ & $\begin{array}{c}\$ 5,000- \\
9,999\end{array}$ & $\begin{array}{c}\$ 15,000- \\
19,999\end{array}$ & $\begin{array}{c}\$ 15,000- \\
19,999\end{array}$ & $\begin{array}{c}\$ 10,000- \\
14,999\end{array}$ \\
\hline Median Household Income & $\begin{array}{c}\$ 25,000- \\
34,999\end{array}$ & $\begin{array}{c}\$ 35,000- \\
44,999\end{array}$ & $\begin{array}{c}\$ 15,000- \\
19,999\end{array}$ & $\begin{array}{c}\$ 10,000- \\
14,999\end{array}$ & $\begin{array}{c}\$ 20,000- \\
24,999\end{array}$ & $\begin{array}{c}\$ 5,000- \\
9,999\end{array}$ & $\begin{array}{c}\$ 10,000- \\
14,999\end{array}$ & $\begin{array}{c}\$ 15,000- \\
19,999\end{array}$ & $\begin{array}{c}\$ 10,000- \\
14,999\end{array}$ \\
\hline Median Household Income & $\begin{array}{c}\$ 25,000- \\
34,999\end{array}$ & $\begin{array}{c}\$ 25,000- \\
34,999\end{array}$ & $\begin{array}{c}\$ 10,000- \\
14,999\end{array}$ & $\begin{array}{c}\$ 10,000- \\
14,999\end{array}$ & $\begin{array}{c}\$ 10,000- \\
14,999\end{array}$ & $\begin{array}{c}\$ 5,000- \\
9,999\end{array}$ & $\begin{array}{c}\$ 10,000- \\
14,999\end{array}$ & $\begin{array}{c}\$ 10,000- \\
14,999\end{array}$ & $\begin{array}{c}\$ 5,000- \\
9,999\end{array}$ \\
\hline Median Household Income & $\begin{array}{c}\$ 25,000- \\
34,999\end{array}$ & $\begin{array}{c}\$ 35,000- \\
44,999\end{array}$ & $\begin{array}{c}\$ 15,000- \\
19,999\end{array}$ & $\begin{array}{c}\$ 15,000- \\
19,999\end{array}$ & $\begin{array}{c}\$ 20,000- \\
24,999\end{array}$ & $\begin{array}{c}\$ 5,000- \\
9,999\end{array}$ & $\begin{array}{c}\$ 15,000- \\
19,999\end{array}$ & $\begin{array}{c}\$ 15,000- \\
19,999\end{array}$ & $\begin{array}{c}\$ 15,000- \\
19,999\end{array}$ \\
\hline \multicolumn{10}{|l|}{ Asian } \\
\hline \% Below Poverty Line & 11.3 & 10.6 & 19.0 & 15.0 & 24.5 & 38.2 & 26.0 & 24.1 & 24.5 \\
\hline \% Below Poverty Line & 11.0 & 10.0 & 22.6 & 21.8 & 24.5 & 38.2 & 26.0 & 25.3 & 24.5 \\
\hline \% Below Poverty Line & 10.7 & 10.1 & 17.8 & 16.5 & 24.5 & 38.2 & 16.9 & 25.3 & 24.5 \\
\hline \% Below Poverty Line & 11.3 & 10.6 & 19.8 & 16.5 & 24.5 & 38.2 & 26.0 & 25.3 & 24.5 \\
\hline \% Below Poverty Line & 11.0 & 10.5 & 17.0 & 15.0 & 24.5 & 38.2 & 16.9 & 24.1 & 24.5 \\
\hline Median Household Income & $\begin{array}{c}\$ 55,000- \\
64,999\end{array}$ & $\begin{array}{c}\$ 55,000- \\
64,999\end{array}$ & $\begin{array}{c}\$ 45,000- \\
54,999\end{array}$ & $\begin{array}{c}\$ 45,000- \\
54,999\end{array}$ & $\begin{array}{c}\$ 25,000- \\
34,999\end{array}$ & $\begin{array}{c}\$ 25,000- \\
34,999\end{array}$ & $\begin{array}{c}\$ 35,000- \\
44,999\end{array}$ & $\begin{array}{c}\$ 35,000- \\
44,999\end{array}$ & $\begin{array}{c}\$ 55,000- \\
64,999\end{array}$ \\
\hline Median Household Income & $\begin{array}{c}\$ 65,000- \\
74,999\end{array}$ & $\begin{array}{c}\$ 65,000- \\
74,999\end{array}$ & $\begin{array}{c}\$ 45,000- \\
54,999\end{array}$ & $\begin{array}{c}\$ 45,000- \\
54,999\end{array}$ & $\begin{array}{c}\$ 25,000- \\
34,999\end{array}$ & $\begin{array}{c}\$ 25,000- \\
34,999\end{array}$ & $\begin{array}{c}\$ 35,000- \\
44,999\end{array}$ & $\begin{array}{c}\$ 35,000- \\
44,999\end{array}$ & $\begin{array}{c}\$ 55,000- \\
64,999\end{array}$ \\
\hline Median Household Income & $\begin{array}{c}\$ 55,000- \\
64,999\end{array}$ & $\begin{array}{c}\$ 55,000- \\
64,999\end{array}$ & $\begin{array}{c}\$ 35,000- \\
44,999\end{array}$ & $\begin{array}{c}\$ 55,000- \\
64,999\end{array}$ & $\begin{array}{c}\$ 25,000- \\
34,999\end{array}$ & $\begin{array}{c}\$ 25,000- \\
34,999\end{array}$ & $\$ 75,000+$ & $\begin{array}{c}\$ 35,000- \\
44,999\end{array}$ & $\begin{array}{c}\$ 55,000- \\
64,999\end{array}$ \\
\hline Median Household Income & $\begin{array}{c}\$ 65,000- \\
74,999\end{array}$ & $\begin{array}{c}\$ 65,000- \\
74,999\end{array}$ & $\begin{array}{c}\$ 45,000- \\
54,999\end{array}$ & $\begin{array}{c}\$ 35,000- \\
44,999\end{array}$ & $\begin{array}{c}\$ 25,000- \\
34,999\end{array}$ & $\begin{array}{c}\$ 25,000- \\
34,999\end{array}$ & $\begin{array}{c}\$ 45,000- \\
54,999\end{array}$ & $\begin{array}{c}\$ 35,000- \\
44,999\end{array}$ & $\begin{array}{c}\$ 55,000- \\
64,999\end{array}$ \\
\hline Median Household Income & $\begin{array}{c}\$ 55,000- \\
64,999\end{array}$ & $\begin{array}{c}\$ 55,000- \\
64,999\end{array}$ & $\begin{array}{c}\$ 45,000- \\
54,999\end{array}$ & $\begin{array}{c}\$ 45,000- \\
54,999\end{array}$ & $\begin{array}{c}\$ 25,000- \\
34,999\end{array}$ & $\begin{array}{c}\$ 25,000- \\
34,999\end{array}$ & $\begin{array}{c}\$ 65,000- \\
74,999\end{array}$ & $\begin{array}{c}\$ 45,000- \\
54,999\end{array}$ & $\begin{array}{c}\$ 55,000- \\
64,999\end{array}$ \\
\hline
\end{tabular}


Table A-3 (continued). Economic Well Being Measures, Ages 25 to 61, by NHIS Income Imputation File

\begin{tabular}{|c|c|c|c|c|c|c|c|c|c|}
\hline & \multirow[b]{2}{*}{ Total } & \multirow[b]{2}{*}{ No Disability } & \multirow{2}{*}{$\begin{array}{c}\text { Disability } \\
\text { At least } 1 \\
\text { of the } 6 \\
\end{array}$} & \multicolumn{2}{|c|}{ Participation Restriction } & \multirow{2}{*}{$\begin{array}{c}\begin{array}{c}\text { Activity } \\
\text { Limitation }\end{array} \\
\text { ADLs }\end{array}$} & \multicolumn{3}{|c|}{ Impairment } \\
\hline & & & & Limitation & IADLs & & Mental & Physical & Sensory \\
\hline \multicolumn{10}{|l|}{ LT High School } \\
\hline \% Below Poverty Line & 28.9 & 23.7 & 41.7 & 46.9 & 52.4 & 42.2 & 46.2 & 44.7 & 38.7 \\
\hline \% Below Poverty Line & 28.7 & 23.2 & 42.0 & 46.8 & 55.2 & 47.0 & 46.8 & 45.2 & 37.6 \\
\hline \% Below Poverty Line & 28.5 & 23.3 & 41.1 & 46.7 & 53.5 & 40.8 & 45.7 & 43.7 & 39.0 \\
\hline \% Below Poverty Line & 28.8 & 23.6 & 41.3 & 46.5 & 53.6 & 42.2 & 44.9 & 43.5 & 36.5 \\
\hline \% Below Poverty Line & 28.3 & 22.8 & 41.7 & 45.7 & 51.5 & 44.6 & 46.5 & 45.1 & 38.1 \\
\hline Median Household Income & $\begin{array}{c}\$ 25,000- \\
34,999\end{array}$ & $\begin{array}{c}\$ 25,000- \\
34,999\end{array}$ & $\begin{array}{c}\$ 15,000- \\
19,999\end{array}$ & $\begin{array}{c}\$ 15,000- \\
19,999\end{array}$ & $\begin{array}{c}\$ 10,000- \\
14,999\end{array}$ & $\begin{array}{c}\$ 10,000- \\
14,999\end{array}$ & $\begin{array}{c}\$ 15,000- \\
19,999\end{array}$ & $\begin{array}{c}\$ 15,000- \\
19,999\end{array}$ & $\begin{array}{c}\$ 20,000- \\
24,999\end{array}$ \\
\hline Median Household Income & $\begin{array}{c}\$ 25,000- \\
34,999\end{array}$ & $\begin{array}{c}\$ 25,000- \\
34,999\end{array}$ & $\begin{array}{c}\$ 15,000- \\
19,999\end{array}$ & $\begin{array}{c}\$ 15,000- \\
19,999\end{array}$ & $\begin{array}{c}\$ 10,000- \\
14,999\end{array}$ & $\begin{array}{c}\$ 10,000- \\
14,999\end{array}$ & $\begin{array}{c}\$ 15,000- \\
19,999\end{array}$ & $\begin{array}{c}\$ 15,000- \\
19,999\end{array}$ & $\begin{array}{c}\$ 20,000- \\
24,999\end{array}$ \\
\hline Median Household Income & $\begin{array}{c}\$ 25,000- \\
34,999\end{array}$ & $\begin{array}{c}\$ 25,000- \\
34,999\end{array}$ & $\begin{array}{c}\$ 15,000- \\
19,999\end{array}$ & $\begin{array}{c}\$ 15,000- \\
19,999\end{array}$ & $\begin{array}{c}\$ 10,000- \\
14,999\end{array}$ & $\begin{array}{c}\$ 15,000- \\
19,999\end{array}$ & $\begin{array}{c}\$ 15,000- \\
19,999\end{array}$ & $\begin{array}{c}\$ 15,000- \\
19,999\end{array}$ & $\begin{array}{c}\$ 20,000- \\
24,999\end{array}$ \\
\hline Median Household Income & $\begin{array}{c}\$ 25,000- \\
34,999\end{array}$ & $\begin{array}{c}\$ 25,000- \\
34,999\end{array}$ & $\begin{array}{c}\$ 15,000- \\
19,999\end{array}$ & $\begin{array}{c}\$ 15,000- \\
19,999\end{array}$ & $\begin{array}{c}\$ 10,000- \\
14,999\end{array}$ & $\begin{array}{c}\$ 10,000- \\
14,999\end{array}$ & $\begin{array}{c}\$ 15,000- \\
19,999\end{array}$ & $\begin{array}{c}\$ 15,000- \\
19,999\end{array}$ & $\begin{array}{c}\$ 20,000- \\
24,999\end{array}$ \\
\hline Median Household Income & $\begin{array}{c}\$ 25,000- \\
34,999\end{array}$ & $\begin{array}{c}\$ 25,000- \\
34,999\end{array}$ & $\begin{array}{c}\$ 15,000- \\
19,999\end{array}$ & $\begin{array}{c}\$ 15,000- \\
19,999\end{array}$ & $\begin{array}{c}\$ 10,000- \\
14,999\end{array}$ & $\begin{array}{c}\$ 15,000- \\
19,999\end{array}$ & $\begin{array}{c}\$ 15,000- \\
19,999\end{array}$ & $\begin{array}{c}\$ 15,000- \\
19,999\end{array}$ & $\begin{array}{c}\$ 20,000- \\
24,999\end{array}$ \\
\hline \multicolumn{10}{|l|}{ High School } \\
\hline \% Below Poverty Line & 11.6 & 9.5 & 19.9 & 23.3 & 26.9 & 33.0 & 30.9 & 20.0 & 19.5 \\
\hline \% Below Poverty Line & 11.3 & 9.3 & 19.5 & 23.1 & 28.0 & 35.1 & 29.6 & 19.1 & 19.6 \\
\hline \% Below Poverty Line & 11.5 & 9.2 & 20.6 & 23.8 & 29.6 & 33.7 & 31.5 & 20.6 & 23.5 \\
\hline \% Below Poverty Line & 11.4 & 9.2 & 20.0 & 23.3 & 26.7 & 32.9 & 30.1 & 19.8 & 23.5 \\
\hline \% Below Poverty Line & 11.1 & 9.0 & 19.4 & 23.5 & 29.9 & 36.9 & 28.8 & 19.6 & 17.7 \\
\hline Median Household Income & $\begin{array}{c}\$ 35,000- \\
44,999\end{array}$ & $\begin{array}{c}\$ 45,000- \\
54,999\end{array}$ & $\begin{array}{c}\$ 25,000- \\
34,999\end{array}$ & $\begin{array}{c}\$ 25,000- \\
34,999\end{array}$ & $\begin{array}{c}\$ 20,000- \\
24,999\end{array}$ & $\begin{array}{c}\$ 15,000- \\
19,999\end{array}$ & $\begin{array}{c}\$ 20,000- \\
24,999\end{array}$ & $\begin{array}{c}\$ 25,000- \\
34,999\end{array}$ & $\begin{array}{c}\$ 25,000- \\
34,999\end{array}$ \\
\hline Median Household Income & $\begin{array}{c}\$ 35,000- \\
44,999\end{array}$ & $\begin{array}{c}\$ 45,000- \\
54,999\end{array}$ & $\begin{array}{c}\$ 25,000- \\
34,999\end{array}$ & $\begin{array}{c}\$ 25,000- \\
34,999\end{array}$ & $\begin{array}{c}\$ 20,000- \\
24,999\end{array}$ & $\begin{array}{c}\$ 15,000- \\
19,999\end{array}$ & $\begin{array}{c}\$ 20,000- \\
24,999\end{array}$ & $\begin{array}{c}\$ 25,000- \\
34,999\end{array}$ & $\begin{array}{c}\$ 25,000- \\
34,999\end{array}$ \\
\hline Median Household Income & $\begin{array}{c}\$ 35,000- \\
44,999\end{array}$ & $\begin{array}{c}\$ 45,000- \\
54,999\end{array}$ & $\begin{array}{c}\$ 25,000- \\
34,999\end{array}$ & $\begin{array}{c}\$ 25,000- \\
34,999\end{array}$ & $\begin{array}{c}\$ 20,000- \\
24,999\end{array}$ & $\begin{array}{c}\$ 15,000- \\
19,999\end{array}$ & $\begin{array}{c}\$ 20,000- \\
24,999\end{array}$ & $\begin{array}{c}\$ 25,000- \\
34,999\end{array}$ & $\begin{array}{c}\$ 25,000- \\
34,999\end{array}$ \\
\hline Median Household Income & $\begin{array}{c}\$ 35,000- \\
44,999\end{array}$ & $\begin{array}{c}\$ 45,000- \\
54,999\end{array}$ & $\begin{array}{c}\$ 25,000- \\
34,999\end{array}$ & $\begin{array}{c}\$ 25,000- \\
34,999\end{array}$ & $\begin{array}{c}\$ 20,000- \\
24,999\end{array}$ & $\begin{array}{c}\$ 15,000- \\
19,999\end{array}$ & $\begin{array}{c}\$ 20,000- \\
24,999\end{array}$ & $\begin{array}{c}\$ 25,000- \\
34,999\end{array}$ & $\begin{array}{c}\$ 25,000- \\
34,999\end{array}$ \\
\hline Median Household Income & $\begin{array}{c}\$ 35,000- \\
44,999\end{array}$ & $\begin{array}{c}\$ 45,000- \\
54,999\end{array}$ & $\begin{array}{c}\$ 25,000- \\
34,999\end{array}$ & $\begin{array}{c}\$ 25,000- \\
34,999\end{array}$ & $\begin{array}{c}\$ 20,000- \\
24,999\end{array}$ & $\begin{array}{c}\$ 15,000- \\
19,999\end{array}$ & $\begin{array}{c}\$ 20,000- \\
24,999\end{array}$ & $\begin{array}{c}\$ 25,000- \\
34,999\end{array}$ & $\begin{array}{c}\$ 25,000- \\
34,999\end{array}$ \\
\hline
\end{tabular}


Table A-3 (continued). Economic Well Being Measures, Ages 25 to 61, by NHIS Income Imputation File

\begin{tabular}{|c|c|c|c|c|c|c|c|c|c|}
\hline & \multirow[b]{2}{*}{ Total } & \multirow[b]{2}{*}{ No Disability } & \multirow{2}{*}{$\begin{array}{c}\text { Disability } \\
\text { At least } 1 \\
\text { of the } 6 \\
\end{array}$} & \multicolumn{2}{|c|}{ Participation Restriction } & \multirow{2}{*}{$\begin{array}{c}\text { Activity } \\
\text { Limitation } \\
\text { ADLs } \\
\end{array}$} & \multicolumn{3}{|c|}{ Impairment } \\
\hline & & & & Limitation & IADLs & & Mental & Physical & Sensory \\
\hline \multicolumn{10}{|l|}{ More Than High School } \\
\hline \% Below Poverty Line & 4.9 & 4.0 & 11.7 & 16.4 & 22.1 & 20.3 & 19.3 & 11.8 & 12.5 \\
\hline \% Below Poverty Line & 4.9 & 3.9 & 11.7 & 16.9 & 21.6 & 20.6 & 17.0 & 12.3 & 10.6 \\
\hline \% Below Poverty Line & 4.8 & 3.8 & 11.6 & 16.9 & 22.6 & 21.7 & 17.3 & 12.3 & 11.7 \\
\hline \% Below Poverty Line & 4.9 & 3.9 & 11.7 & 16.0 & 21.0 & 19.6 & 17.2 & 12.0 & 13.0 \\
\hline \% Below Poverty Line & 4.9 & 3.9 & 11.5 & 16.3 & 22.8 & 20.9 & 17.5 & 12.0 & 12.2 \\
\hline Median Household Income & $\begin{array}{c}\$ 65,000- \\
74,999\end{array}$ & $\begin{array}{c}\$ 65,000- \\
74,999\end{array}$ & $\begin{array}{c}\$ 45,000- \\
54,999\end{array}$ & $\begin{array}{c}\$ 25,000- \\
34,999\end{array}$ & $\begin{array}{c}\$ 25,000- \\
34,999\end{array}$ & $\begin{array}{c}\$ 35,000- \\
44,999\end{array}$ & $\begin{array}{c}\$ 25,000- \\
34,999\end{array}$ & $\begin{array}{c}\$ 45,000- \\
54,999\end{array}$ & $\begin{array}{c}\$ 45,000- \\
54,999\end{array}$ \\
\hline Median Household Income & $\begin{array}{c}\$ 65,000- \\
74,999\end{array}$ & $\begin{array}{c}\$ 65,000- \\
74,999\end{array}$ & $\begin{array}{c}\$ 35,000- \\
44,999\end{array}$ & $\begin{array}{c}\$ 25,000- \\
34,999\end{array}$ & $\begin{array}{c}\$ 25,000- \\
34,999\end{array}$ & $\begin{array}{c}\$ 35,000- \\
44,999\end{array}$ & $\begin{array}{c}\$ 25,000- \\
34,999\end{array}$ & $\begin{array}{c}\$ 45,000- \\
54,999\end{array}$ & $\begin{array}{c}\$ 45,000- \\
54,999\end{array}$ \\
\hline Median Household Income & $\begin{array}{c}\$ 65,000- \\
74,999\end{array}$ & $\begin{array}{c}\$ 65,000- \\
74,999\end{array}$ & $\begin{array}{c}\$ 45,000- \\
54,999\end{array}$ & $\begin{array}{c}\$ 25,000- \\
34,999\end{array}$ & $\begin{array}{c}\$ 25,000- \\
34,999\end{array}$ & $\begin{array}{c}\$ 35,000- \\
44,999\end{array}$ & $\begin{array}{c}\$ 35,000- \\
44,999\end{array}$ & $\begin{array}{c}\$ 45,000- \\
54,999\end{array}$ & $\begin{array}{c}\$ 45,000- \\
54,999\end{array}$ \\
\hline Median Household Income & $\begin{array}{c}\$ 65,000- \\
74,999\end{array}$ & $\begin{array}{c}\$ 65,000- \\
74,999\end{array}$ & $\begin{array}{c}\$ 35,000- \\
44,999\end{array}$ & $\begin{array}{c}\$ 25,000- \\
34,999\end{array}$ & $\begin{array}{c}\$ 25,000- \\
34,999\end{array}$ & $\begin{array}{c}\$ 35,000- \\
44,999\end{array}$ & $\begin{array}{c}\$ 35,000- \\
44,999\end{array}$ & $\begin{array}{c}\$ 45,000- \\
54,999\end{array}$ & $\begin{array}{c}\$ 45,000- \\
54,999\end{array}$ \\
\hline Median Household Income & $\begin{array}{c}\$ 65,000- \\
74,999 \\
\end{array}$ & $\begin{array}{c}\$ 65,000- \\
74,999 \\
\end{array}$ & $\begin{array}{c}\$ 45,000- \\
54,999 \\
\end{array}$ & $\begin{array}{c}\$ 25,000- \\
34,999 \\
\end{array}$ & $\begin{array}{c}\$ 25,000- \\
34,999 \\
\end{array}$ & $\begin{array}{c}\$ 35,000- \\
44,999 \\
\end{array}$ & $\begin{array}{c}\$ 25,000- \\
34,999 \\
\end{array}$ & $\begin{array}{c}\$ 45,000- \\
54,999 \\
\end{array}$ & $\begin{array}{c}\$ 45,000- \\
54,999 \\
\end{array}$ \\
\hline
\end{tabular}

Source: Author's calculations from 2002 National Health Interview Survey (NHIS) 
Table A-4. Standard Errors for Employment Rate Estimates, Ages 25 to 61

\begin{tabular}{|c|c|c|c|c|c|c|c|c|}
\hline \multirow[b]{2}{*}{ \% Employed During... } & \multirow[b]{2}{*}{ No Disability } & \multirow{2}{*}{$\begin{array}{c}\text { Disability } \\
\text { At least } 1 \\
\text { of the } 6 \\
\end{array}$} & \multicolumn{2}{|c|}{ Participation Restriction } & \multirow{2}{*}{$\begin{array}{c}\begin{array}{c}\text { Activity } \\
\text { Limitation }\end{array} \\
\text { ADLs } \\
\end{array}$} & \multicolumn{3}{|c|}{ Impairments } \\
\hline & & & Limitation & IADLs & & Mental & Physical & Sensory \\
\hline \multicolumn{9}{|l|}{ All } \\
\hline Reference Period & 0.363 & 1.085 & 1.147 & 2.202 & 3.235 & 2.119 & 1.293 & 2.667 \\
\hline Sometime in Previous Year & 0.299 & 1.060 & 1.203 & 2.368 & 3.567 & 2.258 & 1.408 & 2.600 \\
\hline Full-Time in Previous Year & 0.457 & 0.943 & 0.882 & 1.522 & 2.894 & 1.873 & 1.168 & 2.690 \\
\hline \multicolumn{9}{|l|}{ Men } \\
\hline Reference Period & 0.389 & 1.593 & 1.688 & 3.408 & 5.637 & 3.896 & 2.071 & 3.217 \\
\hline Sometime in Previous Year & 0.287 & 1.515 & 1.734 & 3.891 & 6.155 & 3.777 & 2.230 & 2.983 \\
\hline Full-Time in Previous Year & 0.579 & 1.509 & 1.413 & 3.030 & 5.560 & 3.277 & 1.975 & 3.392 \\
\hline \multicolumn{9}{|l|}{ Women } \\
\hline Reference Period & 0.553 & 1.326 & 1.517 & 2.931 & 2.917 & 2.424 & 1.534 & 4.575 \\
\hline Sometime in Previous Year & 0.509 & 1.402 & 1.719 & 2.980 & 3.523 & 2.740 & 1.650 & 4.649 \\
\hline Full-Time in Previous Year & 0.618 & 1.163 & 1.098 & 1.968 & 1.185 & 2.161 & 1.384 & 4.353 \\
\hline \multicolumn{9}{|l|}{ White } \\
\hline Reference Period & 0.395 & 1.243 & 1.337 & 2.618 & 2.977 & 2.474 & 1.541 & 2.950 \\
\hline Sometime in Previous Year & 0.330 & 1.223 & 1.465 & 2.839 & 3.343 & 2.680 & 1.615 & 2.875 \\
\hline Full-Time in Previous Year & 0.521 & 1.083 & 1.027 & 1.805 & 1.823 & 2.299 & 1.346 & 2.978 \\
\hline \multicolumn{9}{|l|}{ Black } \\
\hline Reference Period & 0.950 & 2.128 & 2.683 & 3.413 & 10.864 & 5.472 & 2.876 & 8.337 \\
\hline Sometime in Previous Year & 0.764 & 2.507 & 2.946 & 4.186 & 10.575 & 4.702 & 3.299 & 8.128 \\
\hline Full-Time in Previous Year & 1.314 & 2.005 & 2.441 & 2.963 & 11.189 & 4.311 & 2.733 & 8.253 \\
\hline \multicolumn{9}{|l|}{ Hispanic } \\
\hline Reference Period & 0.840 & 2.631 & 2.816 & 5.305 & 5.186 & 4.904 & 3.456 & 6.950 \\
\hline Sometime in Previous Year & 0.707 & 2.653 & 3.240 & 5.816 & 5.186 & 5.383 & 3.707 & 7.283 \\
\hline Full-Time in Previous Year & 1.003 & 2.498 & 2.295 & 0.000 & 0.000 & 3.522 & 2.986 & 9.820 \\
\hline
\end{tabular}


Table A-4. Standard Errors for Employment Rate Estimates, Ages 25 to 61

\begin{tabular}{|c|c|c|c|c|c|c|c|c|}
\hline \multirow[b]{2}{*}{ \% Employed During... } & \multirow[b]{2}{*}{ No Disability } & \multirow{2}{*}{$\begin{array}{c}\text { Disability } \\
\text { At least } 1 \\
\text { of the } 6 \\
\end{array}$} & \multicolumn{2}{|c|}{ Participation Restriction } & \multirow{2}{*}{$\begin{array}{c}\text { Activity } \\
\text { Limitation } \\
\text { ADLs } \\
\end{array}$} & \multicolumn{3}{|c|}{ Impairments } \\
\hline & & & Limitation & IADLs & & Mental & Physical & Sensory \\
\hline \multicolumn{9}{|l|}{ Native American } \\
\hline Reference Period & 6.610 & 6.634 & 7.858 & 3.660 & 11.134 & 12.593 & 7.729 & 14.199 \\
\hline Sometime in Previous Year & 4.367 & 7.476 & 8.740 & 7.691 & 11.134 & 12.568 & 8.502 & 16.064 \\
\hline Full-Time in Previous Year & 6.294 & 4.310 & 2.446 & 0.000 & 0.000 & 12.563 & 4.567 & 4.052 \\
\hline \multicolumn{9}{|l|}{ Asian } \\
\hline Reference Period & 1.793 & 7.638 & 8.417 & 19.320 & 0.000 & 18.999 & 11.351 & 30.588 \\
\hline Sometime in Previous Year & 1.691 & 7.711 & 9.985 & 19.320 & 30.160 & 20.577 & 11.329 & 21.669 \\
\hline Full-Time in Previous Year & 2.242 & 7.326 & 9.567 & 19.320 & 0.000 & 12.814 & 10.446 & 30.588 \\
\hline \multicolumn{9}{|l|}{ LT High School } \\
\hline Reference Period & 1.134 & 1.977 & 1.908 & 2.742 & 2.400 & 4.132 & 2.408 & 5.628 \\
\hline Sometime in Previous Year & 0.972 & 1.944 & 2.062 & 2.950 & 2.750 & 4.523 & 2.595 & 5.731 \\
\hline Full-Time in Previous Year & 1.297 & 1.625 & 1.405 & 1.652 & 0.000 & 3.621 & 1.738 & 5.369 \\
\hline \multicolumn{9}{|l|}{ High School } \\
\hline Reference Period & 0.636 & 1.745 & 1.978 & 4.072 & 3.145 & 3.832 & 2.006 & 4.175 \\
\hline Sometime in Previous Year & 0.553 & 1.793 & 2.257 & 4.721 & 5.680 & 4.102 & 2.200 & 4.115 \\
\hline Full-Time in Previous Year & 0.835 & 1.580 & 1.529 & 2.689 & 2.219 & 3.231 & 1.892 & 4.242 \\
\hline \multicolumn{9}{|l|}{ More Than High School } \\
\hline Reference Period & 0.429 & 1.536 & 1.942 & 3.609 & 6.805 & 3.438 & 2.012 & 3.725 \\
\hline Sometime in Previous Year & 0.335 & 1.418 & 2.013 & 3.756 & 6.764 & 3.304 & 1.857 & 3.299 \\
\hline Full-Time in Previous Year & 0.556 & 1.536 & 1.747 & 3.041 & 6.590 & 3.200 & 1.946 & 4.245 \\
\hline
\end{tabular}


Table A-5. Multiple Disabilities Standard Errors, Respondents Aged 18-64

Standard errors for percent of respondents with at least one disability in each single or dual disability category

\begin{tabular}{|c|c|c|c|c|c|c|}
\hline & Employment & IADLs & ADLs & Physical & Mental & Sensory \\
\hline Employment & 1.233 & 0.793 & 0.606 & 1.133 & 0.316 & 0.697 \\
\hline IADLs & 0.793 & 0.874 & 0.356 & 0.888 & 0.247 & 0.479 \\
\hline ADLs & 0.606 & 0.356 & 0.731 & 0.708 & 0.228 & 0.374 \\
\hline Physical & 1.133 & 0.888 & 0.708 & 0.909 & 0.355 & 0.773 \\
\hline Mental & 0.316 & 0.247 & 0.228 & 0.355 & 0.455 & 0.225 \\
\hline Sensory & 0.697 & 0.479 & 0.374 & 0.773 & 0.225 & 0.963 \\
\hline Category Disability Only & 0.646 & 0.200 & 0.038 & 0.223 & 0.957 & 0.551 \\
\hline
\end{tabular}

Source: Authors’ calculations from 2002 National Health Interview Survey (NHIS).

Note: The first cell in the first column can be interpreted as the percent of disabled respondents with an employment disability.

The second cell in the first column can be interpreted as the percent of disabled respondents with both an employment and IADL disability. 
Table A-6. Multiple Disabilities Standard Errors, Respondents Aged 65+

\begin{tabular}{|c|c|c|c|c|c|c|}
\hline & \multicolumn{6}{|c|}{ Standard errors for percent of respondents with at least one disability in each single or dual disability category } \\
\hline & Employment & IADLs & ADLs & Physical & Mental & Sensory \\
\hline Employment & 0.9619 & 0.6037 & 0.3958 & 0.8893 & 0.5415 & 0.3786 \\
\hline ADLs & 0.3958 & 0.3564 & 0.4051 & 0.3689 & 0.1818 & 0.1282 \\
\hline Physical & 0.8893 & 0.5435 & 0.3689 & 0.9316 & 0.5264 & 0.3889 \\
\hline Sensory & 0.3786 & 0.2070 & 0.1282 & 0.3889 & 0.2193 & 0.6087 \\
\hline Category Disability Only & 0.7207 & 0.0955 & 0.0679 & 0.5015 & 0.8382 & 0.4031 \\
\hline
\end{tabular}

Source: Authors' calculations from 2002 National Health Interview Survey (NHIS).

Note: The first cell in the first column can be interpreted as the percent of disabled respondents with an employment disability.

The second cell in the first column can be interpreted as the percent of disabled respondents with both an employment and IADL disability. 


\begin{tabular}{|c|c|c|c|c|c|c|c|c|c|}
\hline & \multirow[b]{2}{*}{ Total } & \multirow{2}{*}{$\begin{array}{c}\text { No } \\
\text { Disability }\end{array}$} & \multirow{2}{*}{$\begin{array}{c}\text { Disability } \\
\text { At least } 1 \\
\text { of the } 6\end{array}$} & \multicolumn{2}{|c|}{ Participation Restriction } & \multirow{2}{*}{$\begin{array}{c}\begin{array}{c}\text { Activity } \\
\text { Limitation }\end{array} \\
\text { ADLs }\end{array}$} & \multicolumn{3}{|c|}{ Impairment } \\
\hline & & & & Employment & IADLs & & Mental & Physical & Sensory \\
\hline \multicolumn{10}{|l|}{ Employment } \\
\hline Unable to work due to a disability & 0.1918 & 0.0000 & 0.9327 & 1.1355 & 1.9916 & 2.8968 & 1.9531 & 1.2136 & 2.1454 \\
\hline Limited in work due to a disability & 0.1349 & 0.0000 & 0.7266 & 1.1355 & 1.5746 & 2.2924 & 1.0236 & 0.7890 & 1.4110 \\
\hline \multicolumn{10}{|l|}{ IADLs } \\
\hline Needs help with routine care needs & 0.1050 & 0.0000 & 0.6281 & 0.9652 & 0.0000 & 3.1651 & 1.4240 & 0.8634 & 1.7284 \\
\hline \multicolumn{10}{|l|}{ ADLs } \\
\hline Needs help with personal care needs & 0.0674 & 0.0000 & 0.4051 & 0.6726 & 2.2497 & 0.0000 & 0.8931 & 0.5815 & 1.1199 \\
\hline Difficulty with bathing & 0.0506 & NA & 3.7492 & 3.8960 & 3.8627 & 3.7492 & 6.1378 & 4.0416 & 9.1716 \\
\hline Difficulty with dressing & 0.0513 & NA & 3.5358 & 3.6437 & 4.0036 & 3.5358 & 7.3079 & 3.7012 & 10.5340 \\
\hline Difficulty with eating & 0.0285 & NA & 2.9390 & 3.0677 & 3.4364 & 2.9390 & 6.1810 & 3.1108 & 10.1336 \\
\hline Difficulty with getting into bed or chairs & 0.0438 & NA & 3.9542 & 4.1008 & 4.0383 & 3.9542 & 7.7931 & 4.3977 & 10.1883 \\
\hline Difficulty with using the toilet & 0.0350 & NA & 3.3863 & 3.5348 & 3.8789 & 3.3863 & 6.0618 & 3.5578 & 8.9261 \\
\hline Difficulty with getting around the home & 0.0372 & NA & 3.5717 & 3.7400 & 4.0412 & 3.5717 & 7.3737 & 3.9400 & 9.8621 \\
\hline \multicolumn{10}{|l|}{ Mental } \\
\hline Low Kessler index score $^{a}$ & 0.3340 & 0.3157 & 0.8874 & 1.1689 & 2.2381 & 3.5642 & 0.0000 & 1.1701 & 2.5857 \\
\hline Medium Kessler index score ${ }^{b}$ & 0.2993 & 0.3157 & 0.8084 & 1.1370 & 2.2264 & 3.4220 & 0.0000 & 1.0622 & 2.4607 \\
\hline High Kessler index score $^{c}$ & 0.1280 & 0.0000 & 0.6829 & 0.8666 & 1.9901 & 2.8793 & 0.0000 & 0.8188 & 1.8562 \\
\hline \multicolumn{10}{|l|}{ Physical } \\
\hline \multicolumn{10}{|l|}{ Difficulty with/can't.... } \\
\hline ....Walk a quarter of a mile & 0.1412 & 0.0000 & 0.7589 & 1.0990 & 2.5598 & 3.7688 & 1.5593 & 1.0887 & 2.1320 \\
\hline ....Walk 10 steps without resting & 0.1251 & 0.0000 & 0.7261 & 0.9545 & 2.3462 & 3.7072 & 1.4505 & 1.1142 & 1.7396 \\
\hline ....Stand for 2 hours & 0.1714 & 0.0000 & 0.8718 & 1.1914 & 2.4623 & 3.6717 & 1.9684 & 1.2005 & 2.1837 \\
\hline ....Sit for 2 hours & 0.1293 & 0.0000 & 0.7118 & 1.0791 & 2.2852 & 3.3660 & 1.7371 & 1.0908 & 1.9940 \\
\hline ....Stoop, bend or kneel & 0.1882 & 0.0000 & 0.8953 & 1.2149 & 2.3683 & 3.9419 & 1.7377 & 1.1635 & 2.1241 \\
\hline ....Reach over your head & 0.0941 & 0.0000 & 0.5323 & 0.7613 & 1.9086 & 3.3719 & 1.2187 & 0.7952 & 1.8153 \\
\hline ....Grasp small objects & 0.0750 & 0.0000 & 0.4469 & 0.6478 & 1.6720 & 3.4385 & 0.9773 & 0.7118 & 1.5229 \\
\hline ....Lift or carry something as heavy as $10 \mathrm{lbs}$ & 0.1187 & 0.0000 & 0.6658 & 0.9895 & 2.4299 & 4.0448 & 1.6455 & 1.0114 & 1.8075 \\
\hline ....Push or pull large objects & 0.1554 & 0.0000 & 0.8171 & 1.1556 & 2.4904 & 3.9992 & 1.7947 & 1.1570 & 2.2035 \\
\hline
\end{tabular}


Table A-7 (continued). Underlying Indicators of Disability Standard Errors, Respondents Aged 18-64 (Percentages)

\begin{tabular}{|c|c|c|c|c|c|c|c|c|c|}
\hline & \multirow[b]{2}{*}{ Total } & \multirow{2}{*}{$\begin{array}{c}\text { No } \\
\text { Disability }\end{array}$} & \multirow{2}{*}{$\begin{array}{c}\text { Disability } \\
\text { At least } 1 \\
\text { of the } 6\end{array}$} & \multicolumn{2}{|c|}{ Participation Restriction } & \multirow{2}{*}{$\begin{array}{c}\begin{array}{c}\text { Activity } \\
\text { Limitation }\end{array} \\
\text { ADLs }\end{array}$} & \multicolumn{3}{|c|}{ Impairment } \\
\hline & & & & Employment & IADLs & & Mental & Physical & Sensory \\
\hline \multicolumn{10}{|l|}{ Sensory } \\
\hline Blind $^{\mathrm{d}}$ & 0.0350 & 0.0000 & 0.2177 & 0.3094 & 0.8774 & 1.1035 & 0.4074 & 0.2046 & 1.7271 \\
\hline Deaf & 0.0291 & 0.0000 & 0.1804 & 0.2291 & 0.5420 & 0.2973 & 0.3073 & 0.1828 & 1.4871 \\
\hline Difficulty hearing without hearing aid & 0.0843 & 0.0000 & 0.5119 & 0.4819 & 1.0699 & 1.7267 & 0.9238 & 0.5423 & 2.1145 \\
\hline \multicolumn{10}{|c|}{ Source: Authors’ calculations from 2002 National Health Interview Survey (NHIS). } \\
\hline \multicolumn{10}{|c|}{ a) Kessler index score $0-3$} \\
\hline \multicolumn{10}{|l|}{ b) Kessler index score 4-12 } \\
\hline c) Kessler index score 13+ & & & & & & & & & \\
\hline
\end{tabular}




\begin{tabular}{|c|c|c|c|c|c|c|c|c|c|}
\hline & \multirow[b]{2}{*}{ Total } & \multirow{2}{*}{$\begin{array}{c}\text { No } \\
\text { Disability }\end{array}$} & \multirow{2}{*}{$\begin{array}{c}\text { Disability } \\
\text { At least } 1 \\
\text { of the } 6\end{array}$} & \multicolumn{2}{|c|}{ Participation Restriction } & \multirow{2}{*}{$\begin{array}{c}\begin{array}{c}\text { Activity } \\
\text { Limitation }\end{array} \\
\text { ADLs }\end{array}$} & \multicolumn{3}{|c|}{ Impairment } \\
\hline & & & & Employment & IADLs & & Mental & Physical & Sensory \\
\hline \multicolumn{10}{|l|}{ Employment } \\
\hline Unable to work due to a disability & 0.5641 & 0.0000 & 1.0577 & 1.4786 & 2.2327 & 3.2392 & 4.9955 & 1.2307 & 1.8327 \\
\hline Limited in work due to a disability & 0.4748 & 0.0000 & 0.9127 & 1.4786 & 1.5434 & 1.9644 & 3.8314 & 0.9965 & 1.5353 \\
\hline \multicolumn{10}{|l|}{ IADLs } \\
\hline Needs help with routine care needs & 0.4606 & 0.0000 & 0.8738 & 1.2916 & 0.0000 & 2.8689 & 4.7904 & 1.1599 & 1.7665 \\
\hline \multicolumn{10}{|l|}{ ADLs } \\
\hline Needs help with personal care needs & 0.3749 & 0.0000 & 0.7314 & 1.0667 & 2.0268 & 0.0000 & 4.7160 & 0.9401 & 1.3774 \\
\hline Difficulty with bathing & 0.3054 & NA & 2.6415 & 2.8338 & 2.2495 & 2.6415 & 8.5485 & 2.7982 & 5.1795 \\
\hline Difficulty with dressing & 0.2662 & NA & 3.1920 & 3.6461 & 3.1615 & 3.1920 & 10.5012 & 3.5678 & 5.8370 \\
\hline Difficulty with eating & 0.1940 & NA & 2.8343 & 3.2937 & 3.2270 & 2.8343 & 7.3443 & 3.3151 & 4.9597 \\
\hline Difficulty with getting into bed or chairs & 0.2589 & NA & 3.2885 & 3.8832 & 3.5085 & 3.2885 & 11.3919 & 3.4197 & 6.5525 \\
\hline Difficulty with using the toilet & 0.2221 & NA & 3.0568 & 3.4226 & 3.2671 & 3.0568 & 10.5916 & 3.3877 & 6.3457 \\
\hline Difficulty with getting around the home & 0.2399 & NA & 3.3362 & 3.6543 & 3.4323 & 3.3362 & 10.4004 & 3.5382 & 6.1824 \\
\hline \multicolumn{10}{|l|}{ Mental } \\
\hline Low Kessler index score $^{\mathrm{a}}$ & 0.6088 & 0.5873 & 1.0497 & 1.4704 & 2.0993 & 3.4417 & 0.0000 & 1.2505 & 2.0716 \\
\hline Medium Kessler index score ${ }^{\mathrm{b}}$ & 0.5942 & 0.5873 & 1.0116 & 1.4021 & 2.1035 & 3.4494 & 0.0000 & 1.1733 & 1.9310 \\
\hline High Kessler index score ${ }^{c}$ & 0.2168 & 0.0000 & 0.4550 & 0.6018 & 0.9257 & 1.7441 & 0.0000 & 0.4856 & 0.8695 \\
\hline \multicolumn{10}{|l|}{ Physical } \\
\hline \multicolumn{10}{|l|}{ Difficulty with/can't.... } \\
\hline ....Walk a quarter of a mile & 0.6034 & 0.0000 & 1.0499 & 1.4077 & 2.1141 & 3.0398 & 4.7231 & 1.2276 & 1.9486 \\
\hline ....Walk 10 steps without resting & 0.5032 & 0.0000 & 0.9329 & 1.2927 & 1.9358 & 3.0392 & 5.0378 & 1.2105 & 1.8752 \\
\hline ....Stand for 2 hours & 0.6402 & 0.0000 & 1.0879 & 1.4571 & 2.0189 & 2.8847 & 4.9271 & 1.2402 & 2.0602 \\
\hline ....Sit for 2 hours & 0.3087 & 0.0000 & 0.6399 & 0.9195 & 1.3728 & 2.4939 & 3.0865 & 0.8557 & 1.3119 \\
\hline ....Stoop, bend or kneel & 0.5986 & 0.0000 & 1.0058 & 1.3873 & 2.0781 & 3.2679 & 4.9174 & 1.1565 & 1.9906 \\
\hline ....Reach over your head & 0.3311 & 0.0000 & 0.6540 & 0.9227 & 1.6030 & 2.7082 & 4.0328 & 0.8827 & 1.2848 \\
\hline ....Grasp small objects & 0.3195 & 0.0000 & 0.6450 & 0.8807 & 1.4639 & 2.8786 & 4.6663 & 0.8674 & 1.4094 \\
\hline ....Lift or carry something as heavy as $10 \mathrm{lbs}$ & 0.4716 & 0.0000 & 0.9302 & 1.3103 & 2.0278 & 3.2297 & 5.2755 & 1.1954 & 1.6212 \\
\hline ....Push or pull large objects & 0.5304 & 0.0000 & 0.9967 & 1.3421 & 2.0184 & 3.2645 & 5.5908 & 1.2143 & 1.9194 \\
\hline
\end{tabular}


Table A-8 (continued). Underlying Indicators of Disability Standard Errors, Respondents Aged 65+ (Percentages)

\begin{tabular}{|c|c|c|c|c|c|c|c|c|c|}
\hline & \multirow[b]{2}{*}{ Total } & \multirow{2}{*}{$\begin{array}{c}\text { No } \\
\text { Disability } \\
\end{array}$} & \multirow{2}{*}{$\begin{array}{c}\text { Disability } \\
\text { At least } 1 \\
\text { of the } 6 \\
\end{array}$} & \multicolumn{2}{|c|}{ Participation Restriction } & \multirow{2}{*}{$\begin{array}{c}\text { Activity } \\
\text { Limitation } \\
\text { ADLs } \\
\end{array}$} & \multicolumn{3}{|c|}{ Impairment } \\
\hline & & & & Employment & IADLs & & Mental & Physical & Sensory \\
\hline \multicolumn{10}{|l|}{ Sensory } \\
\hline Blind $^{\mathrm{d}}$ & 0.1269 & 0.0000 & 0.2655 & 0.4233 & 0.7581 & 1.1798 & 1.2477 & 0.2826 & 1.0571 \\
\hline Deaf & 0.1397 & 0.0000 & 0.2874 & 0.4143 & 0.5985 & 1.1898 & 0.5752 & 0.3498 & 1.1155 \\
\hline Difficulty hearing without hearing aid & 0.4857 & 0.0000 & 0.9294 & 1.1836 & 1.6505 & 2.3755 & 4.5050 & 0.9352 & 1.4373 \\
\hline $\begin{array}{l}\text { Source: Authors' calculations from } 2002 \mathrm{~N} \\
\text { a) Kessler index score } 0-3 \\
\text { b) Kessler index score } 4-12 \\
\text { c) Kessler index score } 13+\end{array}$ & alth Inter & ew Survey (N & & & & & & & \\
\hline
\end{tabular}




\begin{tabular}{|c|c|c|c|c|c|c|c|c|c|}
\hline & \multirow[b]{2}{*}{ Total } & \multirow{2}{*}{$\begin{array}{c}\text { No } \\
\text { Disability }\end{array}$} & \multirow{2}{*}{$\begin{array}{c}\text { Disability } \\
\text { At least } 1 \\
\text { of the } 6\end{array}$} & \multicolumn{2}{|c|}{ Participation Restriction } & \multirow{2}{*}{$\begin{array}{c}\begin{array}{c}\text { Activity } \\
\text { Limitation }\end{array} \\
\text { ADLs }\end{array}$} & \multirow[b]{2}{*}{ Mental } & \multicolumn{2}{|c|}{ Impairment } \\
\hline & & & & Employment & IADLs & & & Physical & Sensory \\
\hline \multicolumn{10}{|c|}{ Self-reported health status } \\
\hline Excellent/very good & 0.3843 & 0.3534 & 0.8113 & 0.8377 & 1.5736 & 2.6241 & 1.8411 & 0.9831 & 2.4209 \\
\hline Good & 0.3084 & 0.3322 & 0.8005 & 1.0805 & 2.2099 & 3.3146 & 1.7336 & 1.0510 & 2.5324 \\
\hline Fair/poor & 0.2409 & 0.1548 & 0.9102 & 1.1888 & 2.4396 & 3.6623 & 2.0035 & 1.1873 & 2.3002 \\
\hline Don't know/refused & 0.0193 & 0.0195 & 0.0681 & 0.1056 & 0.2672 & 0.0000 & 0.2589 & 0.0959 & 0.3192 \\
\hline \multicolumn{10}{|c|}{ Health status compared to 12 months ago } \\
\hline Better & 0.2978 & 0.3219 & 0.7150 & 0.9073 & 1.9044 & 2.8979 & 1.5228 & 0.8780 & 2.1228 \\
\hline About the same & 0.3468 & 0.3534 & 0.8841 & 1.0596 & 2.3205 & 3.9051 & 2.1167 & 1.1527 & 2.5354 \\
\hline Worse & 0.2032 & 0.1621 & 0.7738 & 1.0211 & 2.4024 & 3.6165 & 1.9769 & 1.0957 & 2.0577 \\
\hline Don't know/refused & 0.0432 & 0.0461 & 0.1065 & 0.1424 & 0.2990 & 0.4070 & 0.2615 & 0.1060 & 0.2890 \\
\hline \multicolumn{10}{|c|}{ Percentage having difficulty performing an activity and having a health problem ${ }^{\mathrm{a}}$} \\
\hline Vision or Seeing & 0.2445 & 0.2003 & 0.4283 & 0.6325 & 1.4194 & 1.9356 & 1.6439 & 0.5364 & 2.2765 \\
\hline Hearing & 0.1298 & 0.0392 & 0.2528 & 0.3968 & 1.1662 & 1.2265 & 0.9529 & 0.2967 & 2.5376 \\
\hline Arthritis & 0.6978 & 0.9265 & 0.9377 & 1.1458 & 2.3674 & 3.6372 & 2.1484 & 1.1058 & 3.3911 \\
\hline Back or Neck & 0.7170 & 1.0579 & 1.0328 & 1.2742 & 2.4606 & 3.9109 & 2.3724 & 1.1756 & 3.3707 \\
\hline Fractures, Bone Injury & 0.5470 & 0.8295 & 0.7050 & 0.8701 & 1.4412 & 2.2001 & 1.7074 & 0.7832 & 2.0595 \\
\hline Other Injury & 0.3104 & 0.4086 & 0.4456 & 0.5839 & 0.9927 & 1.2845 & 0.5646 & 0.5265 & 1.6334 \\
\hline Heart & 0.2911 & 0.2591 & 0.5163 & 0.7407 & 1.4529 & 2.1798 & 1.1918 & 0.5956 & 1.9822 \\
\hline Stroke & 0.1671 & 0.0582 & 0.3329 & 0.5310 & 1.3593 & 1.9866 & 1.0308 & 0.4057 & 1.3766 \\
\hline Hypertension & 0.2686 & 0.2182 & 0.4785 & 0.6450 & 1.2496 & 2.2109 & 1.1430 & 0.5840 & 2.0639 \\
\hline Diabetes & 0.2864 & 0.1807 & 0.5200 & 0.7155 & 1.2746 & 2.1491 & 1.5038 & 0.6197 & 1.7787 \\
\hline Lung & 0.3949 & 0.3909 & 0.6428 & 0.9446 & 1.8431 & 2.7599 & 1.9202 & 0.7359 & 2.4916 \\
\hline Cancer & 0.1437 & 0.1293 & 0.2421 & 0.3677 & 0.7524 & 1.6273 & 0.8074 & 0.2882 & 1.2339 \\
\hline Birth Defect & 0.1119 & 0.1252 & 0.1841 & 0.3020 & 0.5661 & 1.1034 & 0.3161 & 0.2232 & 1.3392 \\
\hline MR & 0.1305 & 0.0918 & 0.2388 & 0.4019 & 0.8567 & 1.7955 & 0.5322 & 0.1488 & 0.9036 \\
\hline Other Developmental & 0.0702 & 0.0502 & 0.1280 & 0.1949 & 0.6374 & 1.1662 & 0.3972 & 0.1276 & 0.6447 \\
\hline Senility & 0.0433 & 0.0140 & 0.0842 & 0.1171 & 0.2454 & 0.0000 & 0.2041 & 0.0785 & 0.5323 \\
\hline Depression, Anxiety & 0.4345 & 0.3914 & 0.6820 & 0.9424 & 2.0744 & 2.7619 & 2.4139 & 0.7378 & 2.8043 \\
\hline
\end{tabular}




\begin{tabular}{|c|c|c|c|c|c|c|c|c|c|}
\hline & \multirow[b]{2}{*}{ Total } & \multirow{2}{*}{$\begin{array}{c}\text { No } \\
\text { Disability }\end{array}$} & \multirow{2}{*}{$\begin{array}{c}\text { Disability } \\
\text { At least } 1 \\
\text { of the } 6\end{array}$} & \multicolumn{2}{|c|}{ Participation Restriction } & \multirow{2}{*}{$\begin{array}{c}\begin{array}{c}\text { Activity } \\
\text { Limitation }\end{array} \\
\text { ADLs }\end{array}$} & \multirow[b]{2}{*}{ Mental } & \multicolumn{2}{|c|}{ Impairment } \\
\hline & & & & Employment & IADLs & & & Physical & Sensory \\
\hline \multirow{2}{*}{\multicolumn{10}{|c|}{$\begin{array}{l}\text { Percentage having difficulty performing an } \\
\text { activity and having a health problem }^{\mathrm{a}}\end{array}$}} \\
\hline & & & & & & & & & \\
\hline Weight & 0.3698 & 0.5618 & 0.4832 & 0.6156 & 1.5035 & 2.5064 & 1.3337 & 0.5622 & 1.6934 \\
\hline Missing Limb & 0.0595 & 0.0202 & 0.1161 & 0.1957 & 0.3300 & 0.6656 & 0.0000 & 0.1267 & 0.5898 \\
\hline Other Musculoskeletal & 0.5455 & 0.7837 & 0.6527 & 0.8203 & 1.8700 & 2.4644 & 1.4164 & 0.7628 & 2.4189 \\
\hline Other Circulatory & 0.2075 & 0.2469 & 0.3445 & 0.4592 & 0.8787 & 1.5979 & 0.7428 & 0.3999 & 1.2208 \\
\hline Other Endocrine & 0.1224 & 0.1126 & 0.2169 & 0.3475 & 0.5553 & 1.0123 & 1.0615 & 0.2694 & 0.5640 \\
\hline Other Nervous & 0.3352 & 0.3744 & 0.5258 & 0.7818 & 1.8913 & 3.1382 & 1.1103 & 0.6158 & 1.8315 \\
\hline Digestive & 0.1328 & 0.1146 & 0.2385 & 0.3047 & 0.7208 & 0.9150 & 0.6396 & 0.2705 & 0.9550 \\
\hline Genitourinary & 0.1701 & 0.1834 & 0.2644 & 0.3688 & 0.9972 & 1.1154 & 0.5074 & 0.3163 & 1.4870 \\
\hline Skin & 0.0431 & 0.0622 & 0.0596 & 0.1006 & 0.1543 & 0.0000 & 0.0906 & 0.0763 & 0.2595 \\
\hline Blood & 0.0413 & 0.0280 & 0.0765 & 0.1153 & 0.3552 & 0.8138 & 0.3095 & 0.0921 & 0.0000 \\
\hline Tumors, Cysts & 0.0591 & 0.0524 & 0.1045 & 0.1480 & 0.4908 & 0.5259 & 0.2730 & 0.1258 & 0.5871 \\
\hline Alcohol and Drugs & NA & NA & 0.0363 & 0.0617 & 0.1952 & 0.4487 & 0.1964 & 0.0314 & NA \\
\hline Other Mental & 0.0916 & 0.1447 & 0.1132 & 0.1897 & 0.5365 & 0.4143 & 0.2983 & 0.0990 & NA \\
\hline Effects from Surgery & 0.1042 & 0.0918 & 0.1852 & 0.1871 & 0.6475 & 0.4536 & 0.2249 & 0.2042 & 0.7250 \\
\hline Old Age & 0.1138 & 0.2193 & 0.0829 & 0.0614 & 0.1222 & 0.2817 & 0.0000 & 0.0783 & 0.5052 \\
\hline Fatigue & 0.1371 & 0.2286 & 0.1644 & 0.2586 & 0.3843 & 0.1666 & 0.7942 & 0.2038 & 0.6083 \\
\hline Pregnancy-Related & 0.1724 & 0.2690 & 0.2177 & 0.1124 & 0.4133 & NA & 0.7422 & 0.2037 & NA \\
\hline \multicolumn{10}{|l|}{ BMI } \\
\hline Underweight & 0.0930 & 0.0995 & 0.2190 & 0.3104 & 0.8122 & 1.6276 & 0.6704 & 0.2998 & 0.5811 \\
\hline Normal & 0.3798 & 0.4116 & 0.7609 & 0.9907 & 2.1750 & 3.4194 & 1.7180 & 0.9078 & 2.3071 \\
\hline Overweight & 0.3646 & 0.3835 & 0.8590 & 1.0642 & 1.9211 & 2.7576 & 1.8832 & 1.0434 & 2.4442 \\
\hline Mild Obesity & 0.2528 & 0.2757 & 0.6289 & 0.8259 & 1.8391 & 3.0741 & 1.4019 & 0.8505 & 2.1200 \\
\hline Moderate Obesity & 0.1594 & 0.1577 & 0.4979 & 0.6921 & 1.5468 & 1.9739 & 1.1697 & 0.6576 & 1.7924 \\
\hline Severe Obesity & 0.1276 & 0.1192 & 0.4729 & 0.5731 & 1.4051 & 2.2636 & 0.8434 & 0.7092 & 1.2735 \\
\hline Missing & 0.1898 & 0.2024 & 0.4104 & 0.5010 & 1.2148 & 2.1084 & 0.8851 & 0.5077 & 0.8712 \\
\hline
\end{tabular}

Source: Author's calculations from 2002 National Health Interview Survey (NHIS) 


\begin{tabular}{|c|c|c|c|c|c|c|c|c|c|}
\hline & \multirow[b]{2}{*}{ Total } & \multirow{2}{*}{$\begin{array}{c}\text { No } \\
\text { Disability }\end{array}$} & \multirow{2}{*}{$\begin{array}{c}\text { Disability } \\
\text { At least } 1 \\
\text { of the } 6\end{array}$} & \multicolumn{2}{|c|}{ Participation Restriction } & \multirow{2}{*}{$\begin{array}{c}\begin{array}{c}\text { Activity } \\
\text { Limitation }\end{array} \\
\text { ADLs }\end{array}$} & \multicolumn{3}{|c|}{ Impairment } \\
\hline & & & & Employment & IADLs & & Mental & Physical & Sensory \\
\hline \multicolumn{10}{|c|}{ Self-reported health status } \\
\hline Excellent/very good & 0.8448 & 1.0796 & 0.9715 & 1.0774 & 1.1162 & 1.5445 & 5.2455 & 0.9850 & 1.6927 \\
\hline Good & 0.7429 & 1.0023 & 1.0440 & 1.3728 & 1.7287 & 2.6827 & 3.9455 & 1.1962 & 2.0369 \\
\hline Fair/poor & 0.7289 & 0.6909 & 1.1638 & 1.4081 & 1.9101 & 2.6190 & 5.3979 & 1.3939 & 2.2766 \\
\hline Don't know/refused & 0.0690 & 0.0668 & 0.1199 & 0.2092 & 0.3973 & 0.1841 & 0.0000 & 0.1522 & 0.0953 \\
\hline \multicolumn{10}{|c|}{ Health status compared to 12 months ago } \\
\hline Better & 0.4780 & 0.6845 & 0.6916 & 1.0167 & 1.3832 & 2.2849 & 3.5739 & 0.8402 & 1.4503 \\
\hline About the same & 0.6461 & 0.7873 & 0.9747 & 1.3240 & 2.0679 & 3.0537 & 5.2920 & 1.1996 & 2.2038 \\
\hline Worse & 0.5127 & 0.4959 & 0.8729 & 1.1291 & 1.9013 & 3.0409 & 5.1263 & 1.0890 & 1.9421 \\
\hline Don't know/refused & 0.0898 & 0.1185 & 0.1406 & 0.2229 & 0.2889 & 0.4545 & 0.0000 & 0.1823 & 0.2597 \\
\hline \multicolumn{10}{|c|}{ Percentage having difficulty performing an activity and having a health problem ${ }^{\text {a }}$} \\
\hline Vision or Seeing & 0.5511 & 0.5234 & 0.7413 & 1.1247 & 1.6666 & 2.7057 & 5.0610 & 0.8331 & 1.9716 \\
\hline Hearing & 0.3575 & 0.3145 & 0.4951 & 0.6773 & 0.9502 & 1.3942 & 3.3404 & 0.4869 & 1.8605 \\
\hline Arthritis & 0.9050 & 1.7512 & 1.0591 & 1.4702 & 2.0820 & 3.1974 & 4.8380 & 1.1801 & 2.2863 \\
\hline Back or Neck & 0.7119 & 1.1645 & 0.8649 & 1.1090 & 1.5753 & 2.3326 & 4.0856 & 0.9334 & 1.9212 \\
\hline Fractures, Bone Injury & 0.5426 & 0.9723 & 0.6783 & 0.9252 & 1.4217 & 2.3072 & 3.3992 & 0.7816 & 1.4898 \\
\hline Other Injury & 0.3009 & 0.5328 & 0.3791 & 0.6659 & 0.7048 & 1.2895 & 1.5709 & 0.4243 & 0.7846 \\
\hline Heart & 0.7220 & 0.7956 & 0.9340 & 1.1940 & 1.7588 & 2.9541 & 4.2750 & 1.0615 & 1.7332 \\
\hline Stroke & 0.3707 & 0.3463 & 0.5282 & 0.8732 & 1.6722 & 2.7884 & 3.6584 & 0.5953 & 1.2417 \\
\hline Hypertension & 0.4732 & 0.4832 & 0.6161 & 0.8467 & 1.2313 & 2.0472 & 3.4864 & 0.7015 & 1.1954 \\
\hline Diabetes & 0.3976 & 0.4854 & 0.5221 & 0.8725 & 1.2243 & 1.7850 & 3.9523 & 0.6061 & 1.1656 \\
\hline Lung & 0.5694 & 0.7798 & 0.6931 & 1.1027 & 1.1925 & 1.5971 & 3.2772 & 0.7672 & 1.6259 \\
\hline Cancer & 0.3002 & 0.3313 & 0.4027 & 0.6154 & 0.9396 & 1.5394 & 3.0093 & 0.4746 & 0.9550 \\
\hline Birth Defect & 0.0000 & 0.0000 & 0.0000 & 0.0000 & 0.0000 & 0.0000 & 0.0000 & 0.0000 & 0.0000 \\
\hline MR & 0.0431 & 0.0000 & 0.0628 & 0.1215 & 0.0000 & 0.0000 & 0.0000 & 0.0760 & 0.0000 \\
\hline Other Developmental & 0.0197 & 0.0000 & 0.0287 & 0.0000 & 0.0000 & 0.0000 & 0.0000 & 0.0348 & 0.0000 \\
\hline Senility & 0.2469 & 0.2898 & 0.3447 & 0.5224 & 0.9857 & 1.8494 & 2.3995 & 0.3668 & 0.8759 \\
\hline Depression, Anxiety & 0.2939 & 0.3036 & 0.3922 & 0.5256 & 0.8237 & 1.3091 & 4.7798 & 0.4264 & 0.7533 \\
\hline
\end{tabular}




\begin{tabular}{|c|c|c|c|c|c|c|c|c|c|}
\hline & \multirow[b]{2}{*}{ Total } & \multirow{2}{*}{$\begin{array}{c}\text { No } \\
\text { Disability }\end{array}$} & \multirow{2}{*}{$\begin{array}{c}\text { Disability } \\
\text { At least } 1 \\
\text { of the } 6\end{array}$} & \multicolumn{2}{|c|}{ Participation Restriction } & \multirow{2}{*}{$\begin{array}{c}\begin{array}{c}\text { Activity } \\
\text { Limitation }\end{array} \\
\text { ADLs }\end{array}$} & \multirow[b]{2}{*}{ Mental } & \multicolumn{2}{|c|}{ Impairment } \\
\hline & & & & Employment & IADLs & & & Physical & Sensory \\
\hline \multicolumn{10}{|c|}{ Percentage having difficulty performing an activity and having a health problem ${ }^{\mathbf{a}}$} \\
\hline Weight & 0.3561 & 0.6139 & 0.4241 & 0.5327 & 0.6513 & 0.9286 & 2.8742 & 0.4965 & 1.0642 \\
\hline Missing Limb & 0.1048 & 0.0000 & 0.1526 & 0.2546 & 0.4752 & 0.8021 & 0.4194 & 0.1849 & 0.3205 \\
\hline Other Musculoskeletal & 0.5760 & 1.0847 & 0.6651 & 0.8780 & 1.1243 & 1.2390 & 2.1428 & 0.7636 & 1.2474 \\
\hline Other Circulatory & 0.3772 & 0.6590 & 0.4926 & 0.7231 & 1.0310 & 1.7323 & 1.3980 & 0.5388 & 1.0300 \\
\hline Other Endocrine & 0.1090 & 0.0927 & 0.1523 & 0.2580 & 0.3985 & 0.6594 & 0.9508 & 0.1750 & 0.3420 \\
\hline Other Nervous & 0.3622 & 0.4638 & 0.4869 & 0.7546 & 1.0210 & 1.9181 & 2.6873 & 0.5537 & 1.0084 \\
\hline Digestive & 0.1515 & 0.3170 & 0.1672 & 0.2422 & 0.3267 & 0.3955 & 0.0000 & 0.2028 & 0.4844 \\
\hline Genitourinary & 0.1717 & 0.2263 & 0.2285 & 0.4173 & 0.6044 & 1.2252 & 1.5801 & 0.2726 & 0.4735 \\
\hline Skin & 0.0486 & 0.0000 & 0.0706 & 0.0533 & 0.1045 & 0.0000 & 0.6625 & 0.0857 & 0.1259 \\
\hline Blood & 0.0607 & 0.1144 & 0.0716 & 0.0000 & 0.0000 & 0.0000 & 0.0000 & 0.0868 & 0.0000 \\
\hline Tumors, Cysts & 0.0414 & 0.0000 & 0.0604 & 0.1166 & 0.0349 & 0.0704 & 0.0000 & 0.0731 & 0.0000 \\
\hline Alcohol and Drugs & NA & NA & NA & NA & NA & NA & NA & NA & NA \\
\hline Other Mental & NA & NA & NA & NA & NA & NA & NA & NA & NA \\
\hline Effects from Surgery & 0.1074 & 0.0000 & 0.1557 & 0.2594 & 0.3680 & 0.6783 & 0.8424 & 0.1591 & 0.2759 \\
\hline Old Age & 0.3807 & 0.8122 & 0.4345 & 0.6153 & 1.0055 & 1.5684 & 0.9187 & 0.4565 & 0.9657 \\
\hline Fatigue & 0.1817 & 0.2770 & 0.2296 & 0.3294 & 0.5393 & 0.9814 & 0.0000 & 0.2183 & 0.6345 \\
\hline Pregnancy-Related & NA & NA & NA & NA & NA & NA & NA & NA & NA \\
\hline \multicolumn{10}{|l|}{ BMI } \\
\hline Underweight & 0.1874 & 0.2485 & 0.3090 & 0.4365 & 0.7102 & 1.3037 & 2.1981 & 0.4082 & 0.7197 \\
\hline Normal & 0.7720 & 1.0378 & 1.0567 & 1.3400 & 1.9894 & 3.2651 & 5.6878 & 1.1856 & 1.9633 \\
\hline Overweight & 0.6357 & 1.0240 & 0.9647 & 1.1971 & 1.7238 & 2.9160 & 4.5446 & 1.1247 & 2.0091 \\
\hline Mild Obesity & 0.5287 & 0.7236 & 0.7966 & 1.1376 & 1.3786 & 2.0748 & 3.9523 & 0.9528 & 1.5109 \\
\hline Moderate Obesity & 0.3171 & 0.2940 & 0.5491 & 0.7507 & 0.9547 & 1.3342 & 1.6992 & 0.6856 & 0.9558 \\
\hline Severe Obesity & 0.2142 & 0.1548 & 0.4090 & 0.4816 & 1.0824 & 1.1072 & 2.5497 & 0.5463 & 0.4808 \\
\hline Missing & 0.2929 & 0.4382 & 0.3917 & 0.5702 & 1.0363 & 1.3014 & 1.1440 & 0.4714 & 0.7804 \\
\hline
\end{tabular}

Source: Author's calculations from 2002 National Health Interview Survey (NHIS) 


\begin{tabular}{|c|c|c|c|c|c|c|c|c|c|}
\hline & \multirow[b]{2}{*}{ Total } & \multirow{2}{*}{$\begin{array}{c}\text { No } \\
\text { Disability }\end{array}$} & \multirow{2}{*}{$\begin{array}{c}\text { Disability } \\
\text { At least } 1 \\
\text { of the } 6\end{array}$} & \multicolumn{2}{|c|}{ Participation Restriction } & \multirow{2}{*}{$\begin{array}{c}\begin{array}{c}\text { Activity } \\
\text { Limitation }\end{array} \\
\text { ADLs } \\
\end{array}$} & \multicolumn{3}{|c|}{ Impairment } \\
\hline & & & & Employment & IADLs & & Mental & Physical & Sensory \\
\hline \multicolumn{10}{|l|}{ Usual place to go when sick } \\
\hline Clinic or health center & 0.4404 & 0.4523 & 0.8605 & 1.0918 & 1.8317 & 2.5002 & 1.8594 & 0.9777 & 1.9626 \\
\hline HMO & 0.4773 & 0.4995 & 0.9405 & 1.1854 & 2.0288 & 2.8252 & 2.1205 & 1.0788 & 2.2571 \\
\hline Hospital emergency room & 0.0886 & 0.0969 & 0.2159 & 0.2327 & 0.2189 & 0.3133 & 0.7094 & 0.2584 & 0.5240 \\
\hline Hospital outpatient department & 0.1012 & 0.1027 & 0.2675 & 0.3962 & 0.8712 & 1.2609 & 0.7337 & 0.3244 & 0.8142 \\
\hline Other & 0.0776 & 0.0710 & 0.2532 & 0.2959 & 0.4734 & 0.5240 & 0.8122 & 0.2460 & 0.6778 \\
\hline Doesn't go to one place & 0.0775 & 0.0918 & 0.0833 & 0.1124 & 0.0764 & 0.0000 & 0.2312 & 0.0907 & 0.0000 \\
\hline Don't know/refused & 0.0331 & 0.0395 & 0.0237 & 0.0399 & 0.0726 & 0.0000 & 0.0000 & 0.0162 & 0.0000 \\
\hline \multicolumn{10}{|c|}{ Place to go for routine or preventive care, if different from usual } \\
\hline Doesn't receive preventive care anywhere & 0.9696 & 1.0092 & 2.2628 & 2.9855 & 6.2745 & 10.6692 & 4.0507 & 3.0011 & 5.9359 \\
\hline Clinic or health center & 0.5034 & 0.5465 & 1.2188 & 1.5156 & 3.8415 & 6.3873 & 2.3799 & 1.9433 & 2.6017 \\
\hline HMO & 0.6961 & 0.7208 & 1.9209 & 2.6197 & 4.9215 & 5.6953 & 3.5237 & 2.5917 & 4.9471 \\
\hline Hospital emergency room & 0.2514 & 0.2582 & 0.8025 & 1.1781 & 1.2654 & 3.0856 & 1.5516 & 1.1718 & 2.1572 \\
\hline Hospital outpatient department & 0.1422 & 0.1563 & 0.4130 & 0.6279 & 1.9712 & 7.5593 & 0.7228 & 0.6561 & 1.1228 \\
\hline Other & 0.2112 & 0.2170 & 0.7170 & 1.2513 & 1.3785 & 4.0523 & 1.2603 & 1.0352 & 1.7924 \\
\hline Doesn't go to one place most often & 0.4363 & 0.4595 & 1.1824 & 1.4201 & 3.0387 & 0.0000 & 2.3061 & 1.8162 & 2.6568 \\
\hline Don't know/refused & 0.3231 & 0.3544 & 0.9127 & 1.3056 & 2.9052 & 1.9989 & 1.0568 & 1.3743 & 3.4081 \\
\hline \multicolumn{10}{|l|}{ Seen/talked to .... in the past 12 months } \\
\hline ....Mental Health Professional & 0.1902 & 0.1787 & 0.7266 & 1.0423 & 2.3120 & 3.5667 & 2.0256 & 0.8791 & 1.7235 \\
\hline ....Eye Doctor & 0.3725 & 0.4169 & 0.8934 & 1.1188 & 2.1805 & 3.3209 & 1.9358 & 1.1443 & 2.7838 \\
\hline ....Foot Doctor & 0.1544 & 0.1491 & 0.5798 & 0.7075 & 1.5495 & 2.4471 & 1.3273 & 0.8003 & 1.6757 \\
\hline ....Chiropractor & 0.2054 & 0.2311 & 0.5910 & 0.7610 & 1.2713 & 1.6296 & 1.3757 & 0.8141 & 1.5497 \\
\hline ....Therapist (PT/OT) & 0.1972 & 0.1747 & 0.7564 & 0.9474 & 2.0325 & 3.6908 & 1.5940 & 1.0511 & 1.9355 \\
\hline .....Nurse Practitioner & 0.2693 & 0.3033 & 0.7021 & 0.9391 & 2.1624 & 3.0588 & 1.6782 & 0.9337 & 2.0659 \\
\hline$\ldots . \mathrm{OB} / \mathrm{GYN}$ & 0.5688 & 0.6311 & 1.2186 & 1.5517 & 2.8680 & 4.2280 & 2.4684 & 1.4979 & 3.7754 \\
\hline ....Medical Specialist & 0.3211 & 0.3272 & 0.9826 & 1.2719 & 2.4518 & 3.9508 & 2.0484 & 1.1999 & 2.8059 \\
\hline ....General Doctor & 0.4217 & 0.4794 & 0.7694 & 0.9089 & 1.6752 & 2.0025 & 1.9517 & 0.9132 & 2.2541 \\
\hline
\end{tabular}


Table A-11 (continued). Health Care Utilization Standard Errors, Respondents Aged 18-64 (Percentages)

\begin{tabular}{|c|c|c|c|c|c|c|c|c|c|}
\hline & \multirow[b]{2}{*}{ Total } & \multirow[b]{2}{*}{ Disability } & \multirow{2}{*}{$\begin{array}{c}\text { Disability } \\
\text { of the } 6\end{array}$} & \multicolumn{2}{|c|}{ Participation Restriction } & \multirow{2}{*}{$\begin{array}{c}\begin{array}{c}\text { Activity } \\
\text { Limitation }\end{array} \\
\text { ADLs } \\
\end{array}$} & \multicolumn{3}{|c|}{ Impairment } \\
\hline & & & & Employment & IADLs & & Mental & Physical & Sensory \\
\hline \multicolumn{10}{|c|}{ Number of times in ER in past 12 months } \\
\hline 0 & 0.3013 & 0.3161 & 0.8838 & 1.1061 & 2.5659 & 3.8801 & 2.1809 & 1.1660 & 2.4010 \\
\hline At least 1 time & 0.2899 & 0.3054 & 0.8778 & 1.0999 & 2.5502 & 3.8782 & 2.1594 & 1.1589 & 2.3998 \\
\hline 1 & 0.2467 & 0.2633 & 0.7052 & 0.9478 & 1.6969 & 2.7500 & 1.5991 & 0.8814 & 2.0161 \\
\hline $2-3$ & 0.1665 & 0.1610 & 0.6078 & 0.7426 & 1.8190 & 3.1134 & 1.4866 & 0.7727 & 1.4413 \\
\hline $4-9$ & 0.0951 & 0.0795 & 0.4329 & 0.6171 & 1.4102 & 2.3660 & 1.2971 & 0.6074 & 1.3964 \\
\hline $10+$ & 0.0306 & 0.0198 & 0.1504 & 0.2356 & 0.7013 & 1.0532 & 0.5369 & 0.2157 & 0.4085 \\
\hline Don't know/refused & 0.0811 & 0.0929 & 0.1832 & 0.2711 & 0.4013 & 0.5667 & 0.2868 & 0.1725 & 0.4515 \\
\hline Receive at home care in past year? & 0.0703 & 0.0518 & 0.3373 & 0.5159 & 1.5696 & 3.1907 & 0.7358 & 0.4743 & 0.9676 \\
\hline \multicolumn{10}{|c|}{ Number of months received at home care } \\
\hline 1-3 months & 3.1826 & 2.3542 & 4.0382 & 4.4504 & 5.8531 & 6.4158 & 8.7248 & 4.4269 & 13.0401 \\
\hline 4-6 months & 1.7083 & 0.0000 & 2.5162 & 2.7310 & 3.3526 & 4.1441 & 6.2708 & 2.4154 & 6.5951 \\
\hline 7-9 months & 0.3163 & 0.9494 & 0.0000 & 0.0000 & 0.0000 & 0.0000 & 0.0000 & 0.0000 & 0.0000 \\
\hline 10-12 months & 2.9383 & 2.1601 & 3.7799 & 4.1783 & 5.8239 & 6.6056 & 7.9268 & 4.2996 & 12.6144 \\
\hline Don't know/refused & 0.2141 & 0.0000 & 0.3167 & 0.3821 & 0.6494 & 0.8013 & 0.0000 & 0.4030 & 0.0000 \\
\hline \multicolumn{10}{|c|}{ Total number of home visits in past 12 months } \\
\hline 1 & 2.9367 & 7.0579 & 1.8541 & 1.0426 & 2.0192 & 0.8256 & 5.5026 & 1.8750 & 3.3699 \\
\hline $2-3$ & 2.8060 & 6.0649 & 2.7954 & 2.4536 & 1.8115 & 1.7574 & 5.9078 & 3.1381 & 10.5905 \\
\hline $4-9$ & 2.8574 & 4.1965 & 3.7707 & 4.1163 & 4.8298 & 4.8574 & 6.1116 & 4.1260 & 10.0709 \\
\hline $10+$ & 3.4179 & 4.4923 & 4.2591 & 4.6079 & 5.2442 & 5.1178 & 8.4273 & 4.5842 & 12.8867 \\
\hline Don't know/refused & 0.2141 & 0.0000 & 0.3167 & 0.3821 & 0.6494 & 0.8013 & 0.0000 & 0.4030 & 0.0000 \\
\hline \multicolumn{10}{|c|}{ Number of office visits in the past 12 months } \\
\hline 0 & 0.3237 & 0.3691 & 0.5260 & 0.5603 & 1.0177 & 0.8684 & 1.4270 & 0.5232 & 1.8688 \\
\hline At least 1 time & 0.3300 & 0.3829 & 0.6101 & 0.7332 & 1.1059 & 1.0978 & 1.4787 & 0.6775 & 1.9598 \\
\hline 1 & 0.3012 & 0.3485 & 0.4321 & 0.4948 & 0.7744 & 0.8093 & 0.8132 & 0.4951 & 1.5264 \\
\hline $2-3$ & 0.3476 & 0.4100 & 0.7130 & 0.8157 & 1.5566 & 3.0461 & 1.5565 & 0.8128 & 1.8732 \\
\hline $4-9$ & 0.3008 & 0.3397 & 0.8391 & 1.1000 & 2.1622 & 3.3399 & 1.5726 & 1.0165 & 2.3734 \\
\hline $10+$ & 0.2414 & 0.2350 & 0.7830 & 1.1946 & 2.4098 & 3.8954 & 1.9871 & 1.0447 & 2.6212 \\
\hline Don't know/refused & 0.1343 & 0.1430 & 0.3157 & 0.4991 & 0.4739 & 0.6855 & 0.5274 & 0.3764 & 0.7094 \\
\hline
\end{tabular}


Table A-11 (continued). Health Care Utilization Standard Errors, Respondents Aged 18-64 (Percentages)

\begin{tabular}{|c|c|c|c|c|c|c|c|c|c|}
\hline & \multirow[b]{2}{*}{ Total } & \multirow{2}{*}{$\begin{array}{l}\text { No } \\
\text { Disability }\end{array}$} & \multirow{2}{*}{$\begin{array}{c}\text { Disability } \\
\text { At least } 1 \\
\text { of the } 6\end{array}$} & \multicolumn{2}{|c|}{ Participation Restriction } & \multirow{2}{*}{$\begin{array}{c}\text { Activity } \\
\text { Limitation } \\
\text { ADLs }\end{array}$} & \multicolumn{3}{|c|}{ Impairment } \\
\hline & & & & Employment & IADLs & & Mental & Physical & Sensory \\
\hline $\begin{array}{l}\text { Health care delayed due to cost in the past } \\
12 \text { months }\end{array}$ & 0.2132 & 0.1943 & 0.7253 & 0.9882 & 1.9423 & 3.0142 & 1.9526 & 0.9781 & 2.0701 \\
\hline $\begin{array}{l}\text { Needed, didn't receive health care due to } \\
\text { cost (past year) }\end{array}$ & 0.1822 & 0.1600 & 0.6538 & 0.8564 & 1.7151 & 2.4759 & 1.6493 & 0.8354 & 1.7594 \\
\hline $\begin{array}{l}\text { Can't afford mental care/counseling in past } \\
12 \text { months }\end{array}$ & 0.1077 & 0.0902 & 0.5015 & 0.6024 & 1.3218 & 1.9037 & 1.7048 & 0.5496 & 1.1824 \\
\hline $\begin{array}{l}\text { Was in hospital overnight in the past } 12 \\
\text { months }\end{array}$ & 0.1928 & 0.1728 & 0.7313 & 1.0424 & 2.2684 & 3.6002 & 1.9223 & 0.9927 & 1.8952 \\
\hline \multicolumn{10}{|l|}{ Number of nights in hospital } \\
\hline 1 & 1.1184 & 1.4673 & 1.5130 & 1.6870 & 2.3190 & 2.8674 & 2.8345 & 1.8513 & 3.8626 \\
\hline $2-9$ & 1.1815 & 1.5025 & 2.0085 & 2.3178 & 3.8568 & 6.0955 & 4.0768 & 2.4788 & 5.3601 \\
\hline $10-59$ & 0.7841 & 0.7238 & 1.6768 & 1.9644 & 3.8762 & 5.6302 & 3.3321 & 2.1225 & 4.2986 \\
\hline $60+$ & 0.2151 & 0.1407 & 0.5156 & 0.7044 & 0.9990 & 1.7748 & 0.7661 & 0.6421 & 0.7950 \\
\hline Don't know/refused & 0.2227 & 0.2333 & 0.4371 & 0.5986 & 1.4266 & 1.8558 & 1.3008 & 0.5485 & 2.7610 \\
\hline $\begin{array}{l}\text { Received care } 10+\text { times in the past } 12 \\
\text { months }\end{array}$ & 0.2242 & 0.1863 & 0.8497 & 1.1997 & 2.4002 & 3.7259 & 1.9320 & 1.1033 & 2.5563 \\
\hline
\end{tabular}

Source: Author's calculations from 2002 National Health Interview Survey (NHIS) 


\begin{tabular}{|c|c|c|c|c|c|c|c|c|c|}
\hline & \multirow[b]{2}{*}{ Total } & \multirow{2}{*}{$\begin{array}{c}\text { No } \\
\text { Disability }\end{array}$} & \multirow{2}{*}{$\begin{array}{c}\text { Disability } \\
\text { At least } 1 \\
\text { of the } 6\end{array}$} & \multicolumn{2}{|c|}{ Participation Restriction } & \multirow{2}{*}{$\begin{array}{c}\begin{array}{c}\text { Activity } \\
\text { Limitation }\end{array} \\
\text { ADLs }\end{array}$} & \multicolumn{3}{|c|}{ Impairment } \\
\hline & & & & Employment & IADLs & & Mental & Physical & Sensory \\
\hline \multicolumn{10}{|l|}{ Usual place to go when sick } \\
\hline Clinic or health center & 0.6312 & 0.7695 & 0.8797 & 1.0998 & 1.3499 & 1.7559 & 3.1744 & 0.9373 & 1.7046 \\
\hline HMO & 0.6654 & 0.8309 & 0.9255 & 1.1480 & 1.5116 & 2.1205 & 3.2410 & 0.9989 & 1.8258 \\
\hline Hospital emergency room & 0.0785 & 0.0675 & 0.1453 & 0.2066 & 0.2010 & 0.1757 & 0.0000 & 0.1981 & 0.4192 \\
\hline Hospital outpatient department & 0.2070 & 0.2811 & 0.2881 & 0.4228 & 0.5577 & 0.9911 & 0.9731 & 0.3818 & 0.5015 \\
\hline Other & 0.0774 & 0.0770 & 0.1372 & 0.1243 & 0.1422 & 0.2100 & 0.8534 & 0.1488 & 0.4164 \\
\hline Doesn't go to one place & 0.0800 & 0.1453 & 0.0554 & 0.0864 & 0.0000 & 0.0000 & 0.0000 & 0.0516 & 0.0995 \\
\hline Don't know/refused & 0.0360 & 0.0000 & 0.0745 & 0.0889 & 0.1796 & 0.3622 & 0.0000 & 0.0305 & 0.2186 \\
\hline \multicolumn{10}{|c|}{ Place to go for routine or preventive care, if different from usual } \\
\hline Doesn't receive preventive care anywhere & 2.5350 & 3.2975 & 3.7804 & 4.3276 & 7.8617 & 9.9698 & 10.8360 & 4.1521 & 8.8985 \\
\hline Clinic or health center & 1.8713 & 2.5410 & 2.7252 & 4.0346 & 4.8554 & 6.4233 & 10.7171 & 3.8201 & 5.3604 \\
\hline HMO & 2.6804 & 3.4092 & 3.9663 & 5.1459 & 7.1502 & 10.0190 & 13.8185 & 4.9049 & 6.3358 \\
\hline Hospital emergency room & 0.6439 & 0.8951 & 0.8704 & 0.0000 & 0.0000 & 0.0000 & 0.0000 & 1.3480 & 0.0000 \\
\hline Hospital outpatient department & 0.7345 & 0.8162 & 1.3711 & 1.6972 & 1.4776 & 1.7423 & 0.0000 & 1.4011 & 4.4552 \\
\hline Other & 0.8133 & 0.7447 & 1.7233 & 2.2701 & 2.8498 & 6.0378 & 0.0000 & 1.9742 & 3.8241 \\
\hline Doesn't go to one place most often & 1.1022 & 1.5617 & 1.5054 & 2.0655 & 2.2237 & 2.1147 & 0.0000 & 1.3526 & 3.2421 \\
\hline Don't know/refused & 1.5990 & 1.8600 & 3.1525 & 4.4868 & 7.4899 & 5.8817 & 7.3942 & 3.5799 & 7.6199 \\
\hline \multicolumn{10}{|l|}{ Seen/talked to .... in the past 12 months } \\
\hline ....Mental Health Professional & 0.2330 & 0.2022 & 0.4540 & 0.6793 & 1.2321 & 1.8307 & 4.0749 & 0.8791 & 1.0724 \\
\hline ....Eye Doctor & 0.7800 & 1.1043 & 1.0015 & 1.4706 & 2.1285 & 3.1798 & 5.2564 & 1.1443 & 2.2697 \\
\hline ....Foot Doctor & 0.5437 & 0.5995 & 0.9431 & 1.0478 & 1.6721 & 2.9174 & 4.0835 & 0.8003 & 1.8960 \\
\hline ....Chiropractor & 0.3734 & 0.5284 & 0.5838 & 0.7980 & 1.1203 & 1.5554 & 2.1157 & 0.8141 & 1.0163 \\
\hline ....Therapist (PT/OT) & 0.4845 & 0.4648 & 0.8678 & 1.1469 & 1.8500 & 3.2202 & 4.9776 & 1.0511 & 1.7644 \\
\hline .....Nurse Practitioner & 0.5243 & 0.6133 & 0.8089 & 1.0868 & 1.5802 & 2.5033 & 2.7956 & 0.9337 & 1.7052 \\
\hline$\ldots . \mathrm{OB} / \mathrm{GYN}$ & 0.7215 & 1.1176 & 0.8602 & 1.2461 & 1.3913 & 2.3252 & 4.0435 & 0.9761 & 1.6634 \\
\hline ....Medical Specialist & 0.7890 & 1.0800 & 0.9985 & 1.3547 & 1.8183 & 3.0986 & 5.2054 & 1.1999 & 2.3098 \\
\hline ....General Doctor & 0.5380 & 0.8350 & 0.6717 & 0.8910 & 1.1487 & 1.8878 & 2.8802 & 0.9132 & 1.5426 \\
\hline
\end{tabular}




\begin{tabular}{|c|c|c|c|c|c|c|c|c|c|}
\hline & \multirow[b]{2}{*}{ Total } & \multirow{2}{*}{$\begin{array}{c}\text { No } \\
\text { Disability }\end{array}$} & \multirow{2}{*}{$\begin{array}{c}\text { Disability } \\
\text { At least } 1 \\
\text { of the } 6 \\
\end{array}$} & \multicolumn{2}{|c|}{ Participation Restriction } & \multirow{2}{*}{$\begin{array}{c}\text { Activity } \\
\text { Limitation } \\
\text { ADLs } \\
\end{array}$} & \multicolumn{3}{|c|}{ Impairment } \\
\hline & & & & Employment & IADLs & & Mental & Physical & Sensory \\
\hline \multicolumn{10}{|c|}{ Number of times in ER in past 12 months } \\
\hline 0 & 0.6421 & 0.7472 & 1.0295 & 1.3812 & 2.0542 & 3.0744 & 5.2961 & 1.1660 & 2.1037 \\
\hline At least 1 time & 0.6232 & 0.7161 & 1.0124 & 1.3693 & 1.9914 & 3.0310 & 5.0878 & 1.1732 & 2.0998 \\
\hline 1 & 0.5563 & 0.6482 & 0.8598 & 1.2387 & 1.6965 & 2.7815 & 4.3608 & 0.8814 & 1.7021 \\
\hline $2-3$ & 0.3664 & 0.4246 & 0.5947 & 0.7636 & 1.3250 & 2.2989 & 3.1630 & 0.7727 & 1.2710 \\
\hline $4-9$ & 0.1941 & 0.1410 & 0.3701 & 0.5723 & 1.0636 & 1.8528 & 1.6518 & 0.6074 & 0.7459 \\
\hline $10+$ & 0.0759 & 0.0754 & 0.1507 & 0.2895 & 0.4712 & 0.5823 & 0.7445 & 0.2157 & 0.2414 \\
\hline Don't know/refused & 0.1600 & 0.2418 & 0.2206 & 0.3144 & 0.4315 & 0.7740 & 1.3828 & 0.1725 & 0.4808 \\
\hline Receive at home care in past year? & 0.3843 & 0.2262 & 0.7234 & 1.0444 & 2.0548 & 3.3238 & 4.1690 & 0.4743 & 1.3614 \\
\hline \multicolumn{10}{|c|}{ Number of months received at home care } \\
\hline $1-3$ months & 2.7680 & 5.9850 & 2.9206 & 3.5924 & 3.6997 & 4.7386 & 8.2211 & 3.1297 & 5.8473 \\
\hline 4-6 months & 1.6521 & 5.6073 & 1.8589 & 2.5174 & 2.4131 & 3.0116 & 2.5950 & 2.0623 & 4.2770 \\
\hline 7-9 months & 0.8753 & 0.0000 & 0.9554 & 0.8334 & 1.1362 & 1.0997 & 0.0000 & 1.0045 & 2.5089 \\
\hline 10-12 months & 2.4823 & 2.1761 & 2.6694 & 3.4872 & 3.5704 & 4.6767 & 5.6674 & 2.9360 & 5.7561 \\
\hline Don't know/refused & 0.7969 & 0.0000 & 0.8723 & 1.3168 & 1.1740 & 1.2364 & 5.8966 & 1.0759 & 2.2452 \\
\hline \multicolumn{10}{|c|}{ Total number of home visits in past 12 months } \\
\hline 1 & 1.7638 & 6.6751 & 1.8320 & 1.7381 & 1.5120 & 3.2295 & 5.2833 & 1.9671 & 2.9975 \\
\hline $2-3$ & 1.9817 & 9.6348 & 1.9280 & 1.7029 & 1.6008 & 2.1354 & 9.4425 & 2.2386 & 3.4165 \\
\hline $4-9$ & 2.6495 & 10.5164 & 2.5987 & 3.3803 & 2.9030 & 3.4221 & 10.7745 & 2.7083 & 4.8575 \\
\hline $10+$ & 2.9188 & 10.2186 & 2.9991 & 3.6214 & 3.3181 & 4.5048 & 12.9114 & 3.2222 & 5.7936 \\
\hline Don't know/refused & 0.8679 & 3.7075 & 0.8901 & 1.3373 & 1.3678 & 1.5194 & 1.4774 & 1.0691 & 1.9319 \\
\hline \multicolumn{10}{|c|}{ Number of office visits in the past 12 months } \\
\hline 0 & 0.4356 & 0.7007 & 0.4835 & 0.6949 & 1.0481 & 1.6295 & 2.3915 & 0.5232 & 1.1643 \\
\hline At least 1 time & 0.5096 & 0.7733 & 0.6370 & 0.9806 & 1.3364 & 2.0884 & 2.7709 & 0.6930 & 1.4528 \\
\hline 1 & 0.4456 & 0.6938 & 0.4920 & 0.6317 & 0.9581 & 1.6593 & 3.4697 & 0.4951 & 1.0717 \\
\hline $2-3$ & 0.6059 & 0.9114 & 0.7827 & 1.0686 & 1.1475 & 2.1103 & 4.4811 & 0.8128 & 1.5501 \\
\hline $4-9$ & 0.7902 & 1.0011 & 1.0946 & 1.4989 & 1.9853 & 3.0536 & 5.1076 & 1.0165 & 2.0400 \\
\hline $10+$ & 0.6051 & 0.6331 & 0.9458 & 1.2878 & 2.1106 & 3.2770 & 4.6766 & 1.0447 & 1.7547 \\
\hline Don't know/refused & 0.2805 & 0.3319 & 0.4350 & 0.6788 & 1.0071 & 1.3845 & 1.5697 & 0.3764 & 0.8308 \\
\hline
\end{tabular}




\begin{tabular}{|c|c|c|c|c|c|c|c|c|c|}
\hline & \multirow[b]{2}{*}{ Total } & \multirow{2}{*}{$\begin{array}{c}\text { No } \\
\text { Disability }\end{array}$} & \multirow{2}{*}{$\begin{array}{c}\text { Disability } \\
\text { At least } 1 \\
\text { of the } 6 \\
\end{array}$} & \multicolumn{2}{|c|}{ Participation Restriction } & \multirow{2}{*}{$\begin{array}{c}\begin{array}{c}\text { Activity } \\
\text { Limitation }\end{array} \\
\text { ADLs } \\
\end{array}$} & \multicolumn{3}{|c|}{ Impairment } \\
\hline & & & & Employment & IADLs & & Mental & Physical & Sensory \\
\hline $\begin{array}{l}\text { Health care delayed due to cost in the past } 12 \\
\text { months }\end{array}$ & 0.2743 & 0.3584 & 0.4350 & 0.6190 & 0.9513 & 1.6905 & 3.8300 & 0.9781 & 0.9334 \\
\hline $\begin{array}{l}\text { Needed, didn't receive health care due to cost } \\
\text { (past year) }\end{array}$ & 0.2155 & 0.2550 & 0.3675 & 0.5436 & 0.8208 & 1.3516 & 2.7629 & 0.8354 & 0.8024 \\
\hline $\begin{array}{l}\text { Can't afford mental care/counseling in past } \\
12 \text { months }\end{array}$ & 0.1352 & 0.1906 & 0.1992 & 0.2102 & 0.3694 & 0.4425 & 2.6984 & 0.5496 & 0.4683 \\
\hline $\begin{array}{l}\text { Was in hospital overnight in the past } 12 \\
\text { months }\end{array}$ & 0.5990 & 0.6481 & 1.0392 & 1.3942 & 2.0945 & 3.2271 & 4.6253 & 0.9927 & 1.8715 \\
\hline \multicolumn{10}{|l|}{ Number of nights in hospital } \\
\hline 1 & 1.1573 & 2.4657 & 1.2494 & 1.5864 & 1.5657 & 2.2925 & 5.1268 & 1.3640 & 2.4994 \\
\hline $2-9$ & 1.6109 & 2.8325 & 1.9228 & 2.4489 & 3.0652 & 4.6612 & 9.0012 & 2.1067 & 4.1405 \\
\hline $10-59$ & 1.3349 & 2.1136 & 1.6611 & 2.2189 & 2.9969 & 4.5962 & 8.4862 & 1.9515 & 3.9312 \\
\hline $60+$ & 0.4324 & 0.3745 & 0.6028 & 0.9560 & 1.5220 & 2.1305 & 3.0995 & 0.6368 & 1.4883 \\
\hline Don't know/refused & 0.5258 & 1.1627 & 0.4840 & 0.8150 & 0.8705 & 1.0249 & 0.0000 & 0.6005 & 0.6524 \\
\hline $\begin{array}{l}\text { Received care } 10+\text { times in the past } 12 \\
\text { months }\end{array}$ & 0.6005 & 0.6686 & 0.9744 & 1.3866 & 2.0748 & 3.0232 & 4.9479 & 1.1033 & 1.9655 \\
\hline
\end{tabular}

Source: Author's calculations from 2002 National Health Interview Survey (NHIS) 


\begin{tabular}{|c|c|c|c|c|c|c|c|c|c|}
\hline & \multirow[b]{2}{*}{ Total } & \multirow[b]{2}{*}{ No Disability } & \multirow{2}{*}{$\begin{array}{c}\text { Disability } \\
\text { At least } 1 \\
\text { of the } 6\end{array}$} & \multicolumn{2}{|c|}{ Participation Restriction } & \multirow{2}{*}{$\begin{array}{c}\text { Activity } \\
\text { Limitation } \\
\text { ADLs } \\
\end{array}$} & \multicolumn{3}{|c|}{ Impairment } \\
\hline & & & & Employment & IADLs & & Mental & Physical & Sensory \\
\hline \multicolumn{10}{|l|}{ All Families } \\
\hline \multicolumn{10}{|c|}{ Amount family spent on health care in past 12 months ${ }^{\text {a }}$} \\
\hline$\$ 0$ & 0.2760 & 0.2922 & 0.5573 & 0.7706 & 1.2317 & 1.8442 & 1.3108 & 0.6772 & 1.4300 \\
\hline Less than $\$ 500$ & 0.4437 & 0.5008 & 0.7646 & 1.0429 & 2.0888 & 3.3834 & 1.7820 & 0.9347 & 2.6372 \\
\hline$\$ 500-\$ 1,999$ & 0.3762 & 0.4086 & 0.9206 & 1.1882 & 2.0015 & 3.2339 & 1.9845 & 1.1090 & 2.5436 \\
\hline$\$ 2,000-\$ 2,999$ & 0.2169 & 0.2290 & 0.5997 & 0.7340 & 1.4402 & 2.2150 & 1.3967 & 0.7755 & 1.6925 \\
\hline$\$ 3,000-\$ 4,999$ & 0.1629 & 0.1625 & 0.5067 & 0.7050 & 1.3820 & 1.9278 & 0.9792 & 0.6631 & 1.5696 \\
\hline$\$ 5,000$ and greater & 0.1392 & 0.1451 & 0.4660 & 0.5945 & 1.2155 & 2.7849 & 1.2024 & 0.6034 & 1.0553 \\
\hline Don't know/refused & 0.1412 & 0.1573 & 0.3633 & 0.4405 & 1.0618 & 1.5922 & 0.6066 & 0.4730 & 1.3050 \\
\hline \multicolumn{10}{|c|}{ Multi-person Families } \\
\hline \multicolumn{10}{|c|}{ Amount family spent on health care in past 12 months ${ }^{\text {a }}$} \\
\hline$\$ 0$ & 0.2364 & 0.2403 & 0.5757 & 0.8047 & 1.1729 & 1.6012 & 1.4740 & 0.7234 & 1.5486 \\
\hline Less than $\$ 500$ & 0.4899 & 0.5380 & 0.8871 & 1.2530 & 2.6443 & 4.0949 & 2.0657 & 1.0911 & 2.9618 \\
\hline$\$ 500-\$ 1,999$ & 0.4248 & 0.4506 & 1.0922 & 1.4805 & 2.5987 & 4.1329 & 2.4043 & 1.3283 & 2.8580 \\
\hline$\$ 2,000-\$ 2,999$ & 0.2464 & 0.2602 & 0.7132 & 0.9027 & 1.9098 & 2.8195 & 1.6810 & 0.9447 & 1.8077 \\
\hline$\$ 3,000-\$ 4,999$ & 0.1889 & 0.1886 & 0.6035 & 0.8759 & 1.8467 & 2.5422 & 1.1812 & 0.7891 & 1.8662 \\
\hline$\$ 5,000$ and greater & 0.1630 & 0.1691 & 0.5669 & 0.7768 & 1.5305 & 3.6084 & 1.4600 & 0.7319 & 1.2712 \\
\hline Don't know/refused & 0.1597 & 0.1779 & 0.4263 & 0.5479 & 1.3545 & 1.9926 & 0.7033 & 0.5483 & 1.5731 \\
\hline \multicolumn{10}{|c|}{ Single Person Families } \\
\hline \multicolumn{10}{|c|}{ Amount family spent on health care in past 12 months ${ }^{\text {a }}$} \\
\hline$\$ 0$ & 0.9736 & 1.1543 & 1.3296 & 1.6383 & 2.9032 & 4.9704 & 2.4823 & 1.5243 & 3.3781 \\
\hline Less than $\$ 500$ & 1.0011 & 1.1951 & 1.4670 & 1.7520 & 3.4416 & 4.8677 & 3.0084 & 1.8944 & 4.1971 \\
\hline$\$ 500-\$ 1,999$ & 0.5853 & 0.6302 & 1.2755 & 1.4696 & 2.7038 & 3.1296 & 2.5291 & 1.5965 & 3.6672 \\
\hline$\$ 2,000-\$ 2,999$ & 0.2408 & 0.2216 & 0.7740 & 0.9084 & 1.5979 & 2.5774 & 1.6713 & 0.9757 & 2.9725 \\
\hline \$3,000-\$4,999 & 0.1674 & 0.1742 & 0.5496 & 0.6425 & 1.2567 & 2.2071 & 1.3928 & 0.7701 & 1.3949 \\
\hline$\$ 5,000$ and greater & 0.1336 & 0.1118 & 0.5137 & 0.6195 & 1.6577 & 2.4657 & 1.1457 & 0.6919 & 1.6742 \\
\hline Don't know/refused & 0.2207 & 0.2527 & 0.4921 & 0.5226 & 1.3791 & 2.1079 & 1.1962 & 0.6757 & 1.1413 \\
\hline
\end{tabular}




\begin{tabular}{|c|c|c|c|c|c|c|c|c|c|}
\hline & \multirow[b]{2}{*}{ Total } & \multirow[b]{2}{*}{ Disability } & \multirow{2}{*}{$\begin{array}{c}\text { Disability } \\
\text { At least } 1 \\
\text { of the } 6\end{array}$} & \multicolumn{2}{|c|}{ Participation Restriction } & \multirow{2}{*}{$\begin{array}{c}\begin{array}{c}\text { Activity } \\
\text { Limitation }\end{array} \\
\text { ADLs }\end{array}$} & \multicolumn{3}{|c|}{ Impairment } \\
\hline & & & & Employment & IADLs & & Mental & Physical & Sensory \\
\hline $\begin{array}{l}\text { No health insurance in past } 12 \\
\text { months, if currently insured }\end{array}$ & 5.3291 & 0.2058 & 0.5501 & 0.6269 & 1.0611 & 1.6233 & 1.6390 & 0.6487 & 0.6487 \\
\hline \multicolumn{10}{|c|}{ Number of months without health insurance given a period without health insurance in past 12 months } \\
\hline 1-3 months & 1.5683 & 1.8095 & 3.3003 & 4.4661 & 9.0948 & 17.7970 & 7.6117 & 4.6748 & 4.6748 \\
\hline 4-6 months & 1.5402 & 1.7220 & 3.1732 & 4.4012 & 9.9391 & 16.9066 & 6.5135 & 4.1120 & 4.1120 \\
\hline 7-9 months & 1.0519 & 1.1916 & 2.2436 & 3.0195 & 6.6943 & 0.0000 & 5.7178 & 2.9149 & 2.9149 \\
\hline 10-12 months & 1.3493 & 1.4582 & 3.0297 & 3.3896 & 6.4468 & 14.4918 & 5.5090 & 4.1791 & 4.1791 \\
\hline Don't know/refused & 0.2758 & 0.3467 & 0.0682 & 0.1271 & 0.5902 & 0.0000 & 0.0000 & 0.1185 & 0.1185 \\
\hline \multicolumn{10}{|l|}{ Source of health insurance } \\
\hline Private only & 0.4208 & 0.4043 & 0.9929 & 1.2137 & 2.3230 & 3.3874 & 2.0419 & 1.2615 & 1.2615 \\
\hline Public only & 0.2485 & 0.2004 & 0.8318 & 1.1469 & 2.3902 & 3.3489 & 2.0949 & 1.0865 & 1.0865 \\
\hline Public and private & 0.2724 & 0.3836 & 0.4379 & 0.6713 & 2.1915 & 2.2284 & 1.0038 & 0.4946 & 1.7800 \\
\hline Single service plan & 0.0978 & 0.0836 & 0.1740 & 0.2714 & NA & NA & 0.2069 & 0.2093 & NA \\
\hline Uninsured & 0.2972 & 0.3283 & 0.6578 & 0.8332 & 1.5486 & 2.0672 & 1.7339 & 0.8030 & 0.8030 \\
\hline Unknown & 0.0583 & 0.0666 & 0.1071 & 0.1401 & 0.3441 & 0.5771 & 0.1849 & 0.1085 & 0.1085 \\
\hline
\end{tabular}

Source: Author's calculations from 2002 National Health Interview Survey (NHIS)

a) Family medical spending excludes costs associated with insurance premiums, over-the-counter medicine, or reimbursed costs 


\begin{tabular}{|c|c|c|c|c|c|c|c|c|c|}
\hline & \multirow[b]{2}{*}{ Total } & \multirow{2}{*}{ No Disability } & \multirow{2}{*}{$\begin{array}{c}\text { Disability } \\
\text { At least } 1 \\
\text { of the } 6\end{array}$} & \multicolumn{2}{|c|}{ Participation Restriction } & \multirow{2}{*}{$\begin{array}{c}\begin{array}{c}\text { Activity } \\
\text { Limitation }\end{array} \\
\text { ADLs }\end{array}$} & \multirow[b]{2}{*}{ Mental } & \multicolumn{2}{|c|}{ Impairment } \\
\hline & & & & Employment $^{\text {a }}$ & IADLs & & & Physical & Sensory \\
\hline \multicolumn{10}{|l|}{ All Families } \\
\hline \multicolumn{10}{|c|}{ Amount family spent on health care in past 12 months ${ }^{\text {a }}$} \\
\hline$\$ 0$ & 0.4268 & 0.6136 & 0.5127 & 0.7087 & 0.8220 & 1.8847 & 2.2544 & 0.6424 & 1.0180 \\
\hline Less than $\$ 500$ & 0.7249 & 1.0532 & 0.9452 & 1.4509 & 2.0006 & 2.5497 & 5.3164 & 1.1062 & 1.9158 \\
\hline$\$ 500-\$ 1,999$ & 0.7115 & 0.9445 & 1.0114 & 1.3843 & 1.9696 & 3.1453 & 4.0515 & 1.2055 & 2.0748 \\
\hline$\$ 2,000-\$ 2,999$ & 0.4583 & 0.5855 & 0.6896 & 0.8747 & 1.3149 & 2.0827 & 3.1969 & 0.8422 & 1.3213 \\
\hline$\$ 3,000-\$ 4,999$ & 0.3621 & 0.5105 & 0.5096 & 0.7099 & 0.9317 & 1.7700 & 3.1347 & 0.6443 & 1.2292 \\
\hline$\$ 5,000$ and greater & 0.3409 & 0.4718 & 0.5107 & 0.7171 & 1.1679 & 1.8583 & 3.1560 & 0.5750 & 1.0767 \\
\hline Don't know/refused & 0.2913 & 0.3929 & 0.4391 & 0.7005 & 1.0263 & 1.5876 & 2.0014 & 0.5109 & 0.9636 \\
\hline \multicolumn{10}{|c|}{ Multi-person Families } \\
\hline \multicolumn{10}{|c|}{ Amount family spent on health care in past 12 months $^{\text {a }}$} \\
\hline$\$ 0$ & 0.4714 & 0.6713 & 0.6265 & 0.8242 & 1.0024 & 2.2767 & 3.1204 & 0.8003 & 1.3617 \\
\hline Less than $\$ 500$ & 0.9206 & 1.3176 & 1.2471 & 1.8359 & 2.8742 & 3.0796 & 7.5763 & 1.4260 & 2.5590 \\
\hline$\$ 500-\$ 1,999$ & 0.9883 & 1.2569 & 1.4707 & 2.0598 & 3.1775 & 4.2828 & 5.4601 & 1.7137 & 2.9244 \\
\hline$\$ 2,000-\$ 2,999$ & 0.6539 & 0.7945 & 1.0315 & 1.3818 & 2.2404 & 2.8380 & 4.9616 & 1.2527 & 1.9514 \\
\hline$\$ 3,000-\$ 4,999$ & 0.5212 & 0.7035 & 0.7874 & 1.1253 & 1.6725 & 2.5320 & 4.6657 & 0.9694 & 1.7846 \\
\hline$\$ 5,000$ and greater & 0.4852 & 0.6556 & 0.7605 & 1.1167 & 2.0774 & 2.5928 & 4.5608 & 0.8448 & 1.5288 \\
\hline Don't know/refused & 0.3656 & 0.4906 & 0.5988 & 1.0034 & 1.5664 & 1.9876 & 2.8855 & 0.6967 & 1.3196 \\
\hline \multicolumn{10}{|c|}{ Single Person Families } \\
\hline \multicolumn{10}{|c|}{ Amount family spent on health care in past 12 months ${ }^{\text {a }}$} \\
\hline$\$ 0$ & 0.7304 & 1.0249 & 0.8588 & 1.2017 & 1.3734 & 3.3566 & 2.8634 & 1.0007 & 1.7503 \\
\hline Less than $\$ 500$ & 0.9028 & 1.3594 & 1.2781 & 1.9023 & 2.2606 & 4.2349 & 6.1422 & 1.4308 & 2.5804 \\
\hline$\$ 500-\$ 1,999$ & 0.8107 & 1.2372 & 1.0950 & 1.5778 & 1.8603 & 3.1723 & 5.1503 & 1.2936 & 2.4486 \\
\hline$\$ 2,000-\$ 2,999$ & 0.4042 & 0.5450 & 0.6207 & 0.7886 & 1.0132 & 1.8819 & 1.3189 & 0.7609 & 1.2531 \\
\hline$\$ 3,000-\$ 4,999$ & 0.3052 & 0.3776 & 0.4587 & 0.7025 & 0.7844 & 1.0498 & 2.5618 & 0.5322 & 1.2675 \\
\hline$\$ 5,000$ and greater & 0.2957 & 0.2736 & 0.4479 & 0.5632 & 0.7851 & 1.5218 & 3.7930 & 0.5697 & 0.9276 \\
\hline Don't know/refused & 0.3951 & 0.5063 & 0.5886 & 0.8776 & 1.1955 & 2.5591 & 2.0820 & 0.6456 & 1.1557 \\
\hline
\end{tabular}


Table A-14 (continued). Health Insurance Standard Errors, Respondents Aged 65+

\begin{tabular}{|c|c|c|c|c|c|c|c|c|c|}
\hline & \multirow[b]{2}{*}{ Total } & \multirow{2}{*}{ No Disability } & \multirow{2}{*}{$\begin{array}{c}\text { Disability } \\
\text { At least } 1 \\
\text { of the } 6\end{array}$} & \multicolumn{2}{|c|}{ Participation Restriction } & \multirow{2}{*}{$\begin{array}{c}\begin{array}{c}\text { Activity } \\
\text { Limitation }\end{array} \\
\text { ADLs }\end{array}$} & \multirow[b]{2}{*}{ Mental } & \multicolumn{2}{|c|}{ Impairment } \\
\hline & & & & Employment $^{a}$ & IADLs & & & Physical & Sensory \\
\hline $\begin{array}{l}\text { No health insurance in past } 12 \\
\text { months, if currently insured }\end{array}$ & 0.0923 & 0.1427 & 0.1032 & 0.1506 & 0.1345 & 0.0000 & 0.0000 & 0.1297 & 0.1297 \\
\hline \multicolumn{10}{|c|}{ Number of months without health insurance given a period without health insurance in past 12 months } \\
\hline $1-3$ months & 8.8776 & 13.4094 & 10.8928 & 9.8799 & 33.1992 & NA & NA & 8.5300 & 8.5300 \\
\hline 4-6 months & 4.9743 & 2.9117 & 11.3395 & 0.0000 & 0.0000 & NA & NA & 13.9287 & 13.9287 \\
\hline 7-9 months & 8.9789 & 8.0477 & 14.9435 & 22.2585 & 33.1992 & NA & NA & 17.2874 & 17.2874 \\
\hline 10-12 months & 12.0673 & 14.5876 & 12.8871 & 21.0926 & 0.0000 & NA & NA & 14.2972 & 14.2972 \\
\hline Don't know/refused & 0.0000 & 0.0000 & 0.0000 & 0.0000 & 0.0000 & NA & NA & 0.0000 & 0.0000 \\
\hline \multicolumn{10}{|l|}{ Source of health insurance } \\
\hline Private only & 0.3245 & 0.5262 & 0.4018 & 0.5387 & 0.6478 & 0.7634 & 1.5105 & 0.4028 & 0.4028 \\
\hline Public only & 0.8083 & 1.0587 & 1.1050 & 1.4272 & 2.2257 & 3.3043 & 4.8341 & 1.2566 & 1.2566 \\
\hline Public and private & 0.9885 & 1.1488 & 1.1531 & 1.5259 & 2.3075 & 3.4659 & 2.9982 & 1.2641 & 2.5128 \\
\hline Single service plan & 0.0457 & NA & 0.0665 & 0.1287 & NA & NA & NA & 0.0907 & NA \\
\hline Uninsured & 0.1640 & 0.2719 & 0.1738 & 0.2324 & 0.4624 & 0.7835 & 1.5678 & 0.1729 & 0.1729 \\
\hline Unknown & 0.0675 & 0.0944 & 0.0969 & 0.1260 & 0.1331 & 0.2220 & 0.0000 & 0.1206 & 0.1206 \\
\hline
\end{tabular}

Source: Author's calculations from 2002 National Health Interview Survey (NHIS)

a) Family medical spending excludes costs associated with insurance premiums, over-the-counter medicine, or reimbursed costs 


\begin{tabular}{|c|c|c|c|c|c|c|c|c|c|}
\hline & \multirow[b]{2}{*}{ Total } & \multirow[b]{2}{*}{ No Disability } & \multirow{2}{*}{$\begin{array}{c}\text { Disability } \\
\text { At least } 1 \\
\text { of the } 6\end{array}$} & \multicolumn{2}{|c|}{ Participation Restriction } & \multirow{2}{*}{$\begin{array}{c}\text { Activity } \\
\text { Limitation } \\
\\
\text { ADLs } \\
\end{array}$} & \multirow[b]{2}{*}{ Mental } & \multicolumn{2}{|c|}{ Impairment } \\
\hline & & & & Employment & IADLs & & & Physical & Sensory \\
\hline \multicolumn{7}{|l|}{ Have health care problem that } & 1.4914 & 0.9779 & 2.0252 \\
\hline $\begin{array}{l}\text { Know of special equipment tha } \\
\text { would help }\end{array}$ & 0.1089 & 0.0624 & 0.5135 & 0.7853 & 2.0196 & 3.4352 & 1.3144 & 0.7540 & 1.9213 \\
\hline \multicolumn{10}{|c|}{$\begin{array}{l}\text { Have difficulty without this special } \\
\text { device }\end{array}$} \\
\hline Always & 2.2501 & 3.8541 & 2.6065 & 2.9141 & 4.4302 & 6.6691 & 6.5238 & 2.9845 & 2.9845 \\
\hline Often & 2.4168 & 3.3116 & 2.7449 & 2.8968 & 4.3051 & 6.1332 & 5.7805 & 2.9955 & 2.9955 \\
\hline Sometimes & 2.2201 & 5.0612 & 2.3650 & 2.6359 & 3.8748 & 4.5413 & 2.7315 & 2.6576 & 2.6576 \\
\hline Rarely & 1.5149 & 4.7103 & 1.3485 & 1.6002 & 2.7498 & 4.1842 & 1.4949 & 1.4608 & 1.4608 \\
\hline Never & 1.1603 & 4.2697 & 0.6836 & 0.5121 & 0.4183 & 1.1393 & 0.0000 & 0.6399 & 0.6399 \\
\hline Don't Know & 0.7042 & 1.1712 & 0.8360 & 1.0294 & 0.4330 & 0.9063 & 2.4369 & 0.8405 & 0.8405 \\
\hline Ever worn a hearing aid & 0.0651 & 0.0472 & 0.3378 & 0.4224 & 0.8818 & 1.1066 & 0.5147 & 0.3724 & 2.3086 \\
\hline \multicolumn{10}{|c|}{ Frequency of wearing a hearing aid } \\
\hline Some of the time & 3.1246 & 6.0144 & 3.5260 & 5.3612 & 3.3304 & 14.1531 & 8.5306 & 6.2385 & 6.2385 \\
\hline None of the time & 3.4580 & 6.4764 & 3.9257 & 6.7357 & 10.2865 & 15.0973 & 14.0786 & 5.1352 & 5.1352 \\
\hline Don't know & 0.2306 & 0.6594 & 0.0000 & 0.0000 & 0.0000 & 0.0000 & 0.0000 & 0.0000 & 0.0000 \\
\hline
\end{tabular}




\begin{tabular}{|c|c|c|c|c|c|c|c|c|c|}
\hline & \multirow[b]{2}{*}{ Total } & \multirow{2}{*}{$\begin{array}{c}\text { No } \\
\text { Disability }\end{array}$} & \multirow{2}{*}{$\begin{array}{c}\text { Disability } \\
\text { At least } 1 \\
\text { of the } 6 \\
\end{array}$} & \multicolumn{2}{|c|}{ Participation Restriction } & \multirow{2}{*}{$\begin{array}{c}\begin{array}{c}\text { Activity } \\
\text { Limitation }\end{array} \\
\text { ADLs } \\
\end{array}$} & \multicolumn{3}{|c|}{ Impairment } \\
\hline & & & & Employment $^{\text {a }}$ & IADLs & & Mental & Physical & Sensory \\
\hline $\begin{array}{l}\text { Have health care problem that } \\
\text { requires special equipment }\end{array}$ & 0.5992 & 0.2842 & 1.0272 & 1.3921 & 1.9223 & 2.4331 & 5.2041 & 1.2228 & 1.9801 \\
\hline $\begin{array}{l}\text { Now use special } \\
\text { equipment/assistance device }\end{array}$ & 0.6145 & 0.3586 & 1.0598 & 1.4251 & 2.0282 & 2.7657 & 4.9948 & 1.2572 & 2.1844 \\
\hline $\begin{array}{l}\text { Know of special equipment that } \\
\text { would help }\end{array}$ & 0.2759 & 0.2061 & 0.5586 & 0.8480 & 1.2842 & 2.1440 & 3.7375 & 0.6612 & 1.2856 \\
\hline \multicolumn{10}{|l|}{$\begin{array}{l}\text { Have difficulty without this special } \\
\text { device }\end{array}$} \\
\hline Always & 3.1852 & 4.5196 & 3.4662 & 4.2983 & 5.2859 & 7.0362 & 13.3828 & 3.7459 & 3.7459 \\
\hline Often & 3.2827 & 9.5020 & 3.4161 & 4.1801 & 5.5060 & 7.3520 & 12.6366 & 3.5282 & 3.5282 \\
\hline Sometimes & 2.9820 & 8.6441 & 3.2576 & 4.0227 & 4.2850 & 5.4569 & 7.0077 & 3.7260 & 3.7260 \\
\hline Rarely & 1.1416 & 6.8945 & 1.1660 & 1.4148 & 0.9987 & 0.4393 & 1.4722 & 1.2878 & 1.2878 \\
\hline Never & 1.5884 & 5.6125 & 1.5861 & 1.6151 & 0.9927 & 0.0000 & 4.5964 & 1.6777 & 1.6777 \\
\hline Don't Know & 1.3237 & 0.0000 & 1.5437 & 2.2048 & 2.3584 & 3.5261 & 0.0000 & 1.8357 & 1.8357 \\
\hline Ever worn a hearing aid & 0.5365 & 0.5188 & 0.9110 & 1.0850 & 1.4239 & 2.0762 & 3.7037 & 0.9332 & 2.0737 \\
\hline \multicolumn{10}{|l|}{$\begin{array}{l}\text { Frequency of wearing a hearing } \\
\text { aid }\end{array}$} \\
\hline Always & 1.8557 & 2.9244 & 2.1176 & 3.2754 & 8.8574 & 6.7767 & 6.8686 & 2.8242 & 2.8242 \\
\hline Most of the time & 1.7048 & 3.1564 & 1.9549 & 2.9479 & 10.8144 & 5.6618 & 5.3041 & 2.4218 & 2.4218 \\
\hline Some of the time & 1.9398 & 4.0992 & 2.1687 & 3.4733 & 3.3304 & 8.0724 & 12.0662 & 2.8259 & 2.8259 \\
\hline None of the time & 1.4963 & 3.5218 & 1.5269 & 2.4626 & 10.2865 & 5.7424 & 10.8370 & 1.9422 & 1.9422 \\
\hline Don't know & 0.0000 & 0.0000 & 0.0000 & 0.0000 & 0.0000 & 0.0000 & 0.0000 & 0.0000 & 0.0000 \\
\hline
\end{tabular}

Source: Author's calculations from 2002 National Health Interview Survey (NHIS) 


\section{Appendix D. Sample Sizes of Sub-populations}

Table A-17. Sample Size for Questions Asked of Subpopulation

Health Insurance

Adult Elderly

Amount family spent on health care in past 12 months, single person family

6,726 3,002

Amount family spent on health care in past 12 months, multi-person family

$18,458 \quad 2,858$

No health insurance in past 12 months, if currently insured

$20,258 \quad 5,781$

Number of months without health insurance in past 12 months

$1,180 \quad 29$

\section{Special Equipment}

Have difficulty without this special device

$503 \quad 264$

Frequency of wearing a hearing aid

\section{Health Care Utilization}

Usual place to go when sick

$20,789 \quad 5,587$

Place to go for routine or preventive care, if different from usual

Seen/talked to OB/GYN in the past 12 months

$13,859 \quad 3,680$

Number of months received at home care

$248 \quad 403$

Total number of home visits in past 12 months

$248 \quad 403$

Number of nights in hospital

$2,155 \quad 1,173$

\section{Health Status}

Percentage having difficulty performing an activity and having a health problem

6,303

3,636 


\section{Cornell University}

School of Industrial and Labor Relations

Employment and Disability Institute

For more information about the Rehabilitation

Research and Training Center on Disability

Demographics and Statistics contact:

Andrew J. Houtenville

Employment and Disability Institute

Cornell University

303 ILR Extension Building

Ithaca, New York 14853-3901

Tel

607.255 .5702

Fax

607.255 .2763

TTY

607.255 .2891

Email ajh29@cornell.edu

Web www.edi.cornell.edu 